\title{
ANALYSIS OF DEVONIAN BLACK SHALES IN KENTUCKY FOR POTENTIAL CARBON DIOXIDE SEQUESTRATION AND ENHANCED NATURAL GAS PRODUCTION
}

\author{
Seventh Quarter \\ January 1, 2004 to March 31, 2004 \\ Brandon C. Nuttall \\ Report Issued: April, 2004 \\ DE-FC26-02NT41442 \\ Kentucky Geological Survey \\ 228 Mining and Mineral Resources Building \\ University of Kentucky \\ Lexington, Kentucky 40506-0107
}




\section{Disclaimer}

This report was prepared as an account of work sponsored by an agency of the United States Government. Neither the United States Government nor any agency thereof, nor any of their employees, makes any warranty, express or implied, or assumes any legal liability or responsibility for the accuracy, completeness, or usefulness of any information, apparatus, product, or process disclosed, or represents that its use would not infringe privately owned rights. Reference herein to any specific commercial product, process, or service mark by trade name, trademark, manufacturer, or otherwise does not necessarily constitute or imply its endorsement, recommendation, or favoring by the United States Government or any agency thereof. The view and opinions of authors expressed herein do not necessarily state or reflect those of the United States Government or any agency thereof. 


\section{Abstract}

$\mathrm{CO}_{2}$ emissions from the combustion of fossil fuels have been linked to global climate change. Proposed carbon management technologies include geologic sequestration of $\mathrm{CO}_{2}$. A possible, but untested, sequestration strategy is to inject $\mathrm{CO}_{2}$ into organic-rich shales. Devonian black shales underlie approximately two-thirds of Kentucky and are thicker and deeper in the Illinois and Appalachian Basin portions of Kentucky than in central Kentucky. The Devonian black shales serve as both the source and trap for large quantities of natural gas; total gas in place for the shales in Kentucky is estimated to be between 63 and 112 trillion cubic feet. Most of this natural gas is adsorbed on clay and kerogen surfaces, analogous to methane storage in coal beds. In coals, it has been demonstrated that $\mathrm{CO}_{2}$ is preferentially adsorbed, displacing methane. Black shales may similarly desorb methane in the presence of $\mathrm{CO}_{2}$.

The concept that black, organic-rich Devonian shales could serve as a significant geologic sink for $\mathrm{CO}_{2}$ is the subject of current research. To accomplish this investigation, drill cuttings and cores were selected from the Kentucky Geological Survey Well Sample and Core Library. Methane and carbon dioxide adsorption analyses are being performed to determine the gas-storage potential of the shale and to identify shale facies with the most sequestration potential. In addition, sidewall core samples are being acquired to investigate specific black-shale facies, their potential $\mathrm{CO}_{2}$ uptake, and the resulting displacement of methane. Advanced logging techniques (elemental capture spectroscopy) are being investigated for possible correlations between adsorption capacity and geophysical log measurements.

For the Devonian shale, average total organic carbon is 3.71 percent (as received) and mean random vitrinite reflectance is 1.16. Measured adsorption isotherm data range from 37.5 to 2,077.6 standard cubic feet of $\mathrm{CO}_{2}$ per ton (scf/ton) of shale. At 500 psia, adsorption capacity of the Lower Huron Member of the shale is $72 \mathrm{scf} / \mathrm{ton}$.

Initial estimates indicate a sequestration capacity of 5.3 billion tons $\mathrm{CO}_{2}$ in the Lower Huron Member of the Ohio shale in parts of eastern Kentucky and as much as 28 billion tons total in the deeper and thicker portions of the Devonian shales in Kentucky. The black shales of Kentucky could be a viable geologic sink for $\mathrm{CO}_{2}$, and their extensive occurrence in Paleozoic basins across North America would make them an attractive regional target for economic $\mathrm{CO}_{2}$ storage and enhanced natural gas production. 
Table of Contents

DISCLAIMER I

ABSTRACT II

TABLE OF CONTENTS III

TABLES IV

FIGURES IV

EXECUTIVE SUMMARY

TECHNOLOGY TRANSFER SUMMARY 1

ACKNOWLEDGEMENTS 2

INTRODUCTION 2

EXPERIMENTAL 3

RESULTS AND DISCUSSION 3

Total Organic Carbon $\quad 11$

Reflectance Analyses $\quad 12$

Drilling $\quad 12$

$\mathrm{CO}_{2}$ Adsorption Isotherms $\quad 13$

$\begin{array}{ll}\text { CONCLUSION } & 17\end{array}$

REFERENCES CITED $\quad 18$

$\begin{array}{lc}\text { BIBLIOGRAPHY } & 18\end{array}$

APPENDIX A: SUMMARY OF ADSORPTION ISOTHERMS 40

APPENDIX B: GIS ANALYSIS OF THE DISTRIBUTION AND ESTIMATED CO2 STORAGE VOLUME OF THE DEVONIAN SHALE IN KENTUCKY $\quad 56$

APPENDIX C: CNR 24752 ELK HORN COAL 64 


\section{Tables}

Table 1. Initial selection of candidate wells to sample for the Devonian Shale $\mathrm{CO}_{2}$ Sequestration project.

Table 2. Gas storage capacity, TOC, and vitrinite reflectance data for completed samples.

Table 3. Summary of $\mathrm{CO}_{2}$ adsorption capacity in standard cubic feet per ton at selected pressures.

\section{Figures}

Figure 1. Map of the distribution of the Devonian shale in Kentucky, showing the occurrence of deeper and thicker shale with possibly greater potential for geologic sequestration of $\mathrm{CO}_{2}$

Figure 2. Map showing distribution and nomenclature of Devonian shales of Kentucky (Hamilton-Smith, 1993, p. 3)

Figure 3. Nomenclature of Mississippian and Devonian shales of eastern Kentucky and key to names and codes used for intervals sampled.

Figure 4. Initial distribution of Devonian shale drill cuttings sample sets....................... 7

Figure 5. Eastern Kentucky Devonian Shale CO2 Sequestration sample locations........ 7

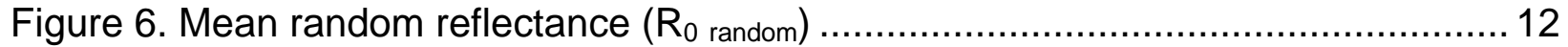

Figure 7. Location of the Columbia Natural Resources 24752 Elk Horn Coal Company well, permit 94539, Knott County, Kentucky Carter coordinate 11-K-81, latitude $37.37019^{\circ} \mathrm{N}$, longitude $82.76441^{\circ} \mathrm{W}$ (NAD 1983).

Figure 8 . Summary of adsorption isotherms by formation

Figure 9. Average calculated adsorption capacities by formation at selected pressures

Figure 10. Preliminary estimated $\mathrm{CO}_{2}$ storage capacity per square kilometer in million tons in the areas of deeper ( $>=1,000$ feet) and thicker ( $>=50$ feet) Devonian shale. 


\section{Executive Summary}

Increased emissions of $\mathrm{CO}_{2}$, especially from the combustion of fossil fuels, are being linked to global climate change and are of considerable global concern. These concerns are driving initiatives to develop carbon management technologies, including geologic sequestration of $\mathrm{CO}_{2}$. One option for sequestration may be Devonian black shales, organic-rich rocks that serve as both the source and trap for natural gas. Most of the natural gas is adsorbed on clay and kerogen surfaces, very similar to the way methane is stored within coal beds. It has been demonstrated in gassy coals that, on average, $\mathrm{CO}_{2}$ is preferentially adsorbed, displacing methane at a ratio of two for one. Black shales may similarly desorb methane in the presence of adsorbing $\mathrm{CO}_{2}$. If this is the case, black shales may be an excellent sink for $\mathrm{CO}_{2}$ and have the added benefit of serving to enhance natural-gas production. A bibliography of Devonian shale has been compiled to identify previous work and provide supporting data for continued research.

Because of the volume of material lost during washing the sampling protocol has been modified to collect cuttings before washing. Unwashed candidate samples have been selected and are being prepared for total organic carbon (TOC), vitrinite reflectance $\left(\mathrm{R}_{0 \text { random }}\right)$, and petrographic and $\mathrm{CO}_{2}$ adsorption analyses to determine the gas-storage potential of the shale and to identify shale facies with the most sequestration potential. For the Devonian shale, average total organic carbon is 3.71 (as received) and mean random vitrinite reflectance is 1.16 .

Columbia Natural Resources has provided access to a selected drill hole of opportunity for collecting sidewall cores and an advanced logging suite for correlation and mineralogical analysis. Sidewall cores have been submitted for methane and $\mathrm{CO}_{2}$ adsorption isotherms and methane displacement analyses.

No new adsorption isotherms were completed during this quarter. Samples were submitted for x-ray diffraction analysis to assist in mineral characterization and correlating results from electron capture spectroscopy logging. Arrangements were made to obtain access to samples from the Battelle deep well in Mason County, West Virginia (AEP \#1) to obtain both methane and $\mathrm{CO}_{2}$ adsorption isotherms. Much of the quarter was devoted to preparing presentations and manuscripts for the upcoming GSA, DOE Project Review, AAPG, and Carbon Sequestration meetings (see Technology Transfer Summary)

Measured $\mathrm{CO}_{2}$ adsorption capacity ranges from 37 to 2,078 standard cubic feet $\mathrm{CO}_{2}$ per ton of shale. The values representing the higher end of this range are problematic and the samples are being re-processed. Initial estimates at $68 \mathrm{scf} /$ ton indicate a sequestration capacity of 5.3 billion tons $\mathrm{CO}_{2}$ in the Lower Huron Member of the Ohio shale in parts of eastern Kentucky. At 500 psia, adsorption capacity of the Lower Huron Member of the shale averages $72 \mathrm{scf} / \mathrm{ton}$. Assuming a thickness weighted average adsorption capacity of $40 \mathrm{scf} / \mathrm{ton}$, as much as 28 billion tons total in the deeper and thicker portions of the Devonian shales in Kentucky. The black shales of Kentucky could be a viable geologic sink for $\mathrm{CO}_{2}$, and their extensive occurrence in Paleozoic basins across North America would make them an attractive regional target for economic $\mathrm{CO}_{2}$ storage and enhanced natural gas production.

\section{Technology Transfer Summary}

- NE/SE Combined GSA Section Meeting, April 2-5, 2002, Lexington, KY

- 2nd National Conference on Carbon Sequestration (NETL), May 5-8, 2003, Alexandria, VA: (poster session)

- Kentucky Oil and Gas Association Annual Meeting, June 23-25, 2003, Louisville, KY

- 2003 GSA Annual Meeting and Exposition, November 2-5, 2003, Seattle, WA

- NE/SE Combined GSA Section Meeting, March 25-27, 2004, Washington, DC

- DOE/NETL Carbon Sequestration Project Review, March 29 to April 1, 2004, Pittsburgh, PA

- AAPG Annual Meeting, April 18-21, 2004, Dallas, TX:: (upcoming, abstract accepted) 
- 3rd Annual Conference on Carbon Sequestration (NETL), May 2-6, 2004, Alexandria, VA: (upcoming, abstract accepted)

- 7th International Conference on Greenhouse Gas Control Technologies, September 5-9, 2004, Vancouver, BC, Canada: (upcoming, abstract accepted)

\section{Acknowledgements}

Contributions to this report have been made by co-investigators Cortland Eble (Kentucky Geological Survey) and R. Marc Bustin (University of British Columbia). Jay Terry of Schlumberger Oilfield Services and Ed Rothman of Columbia Natural Resources have been very helpful in making arrangements to select a well of opportunity and obtain sidewall cores and advanced well log data for a shale well.

\section{Introduction}

Since the discovery of natural gas production from the Devonian shales of Kentucky between 1858 and 1865 , these carbonaceous shales have constituted an important energy resource in Kentucky. Thick and deep sequences of shale exist in both the Illinois and Appalachian Basins (Figure 1). Greenhouse gases, $\mathrm{CO}_{2}$ emissions in particular, are being linked to global climate change. If regulations are adopted that require limiting $\mathrm{CO}_{2}$ emissions, disposal strategies must be identified. Using $\mathrm{CO}_{2}$ flooding of coals as a model, the large component of adsorbed natural gas in organic-rich shales suggest that black shale might be an attractive sequestration target.

The project is concentrating on the Devonian Ohio shale of eastern Kentucky (Figure 2). This area is both the most active area (number of wells drilled over the past 5 years) and the most prolific natural gas producing area in the state accounting for 98 percent of Kentucky's gas production. The Kentucky Geological Survey maintains an extensive collection of cuttings recovered during oil and gas well drilling in the Well Sample and Core Library.

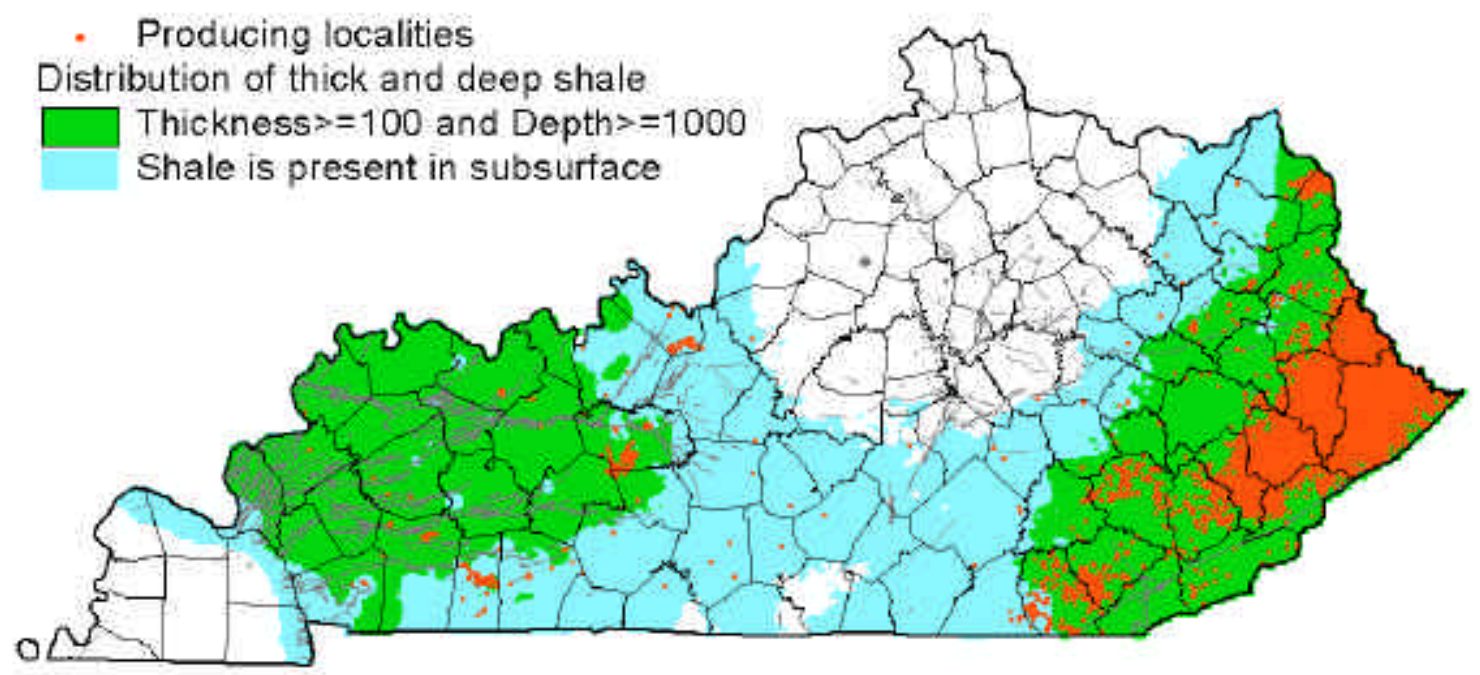

Figure 1. Map of the distribution of the Devonian shale in Kentucky, showing the occurrence of deeper and thicker shale with possibly greater potential for geologic sequestration of $\mathrm{CO}_{2}$. 


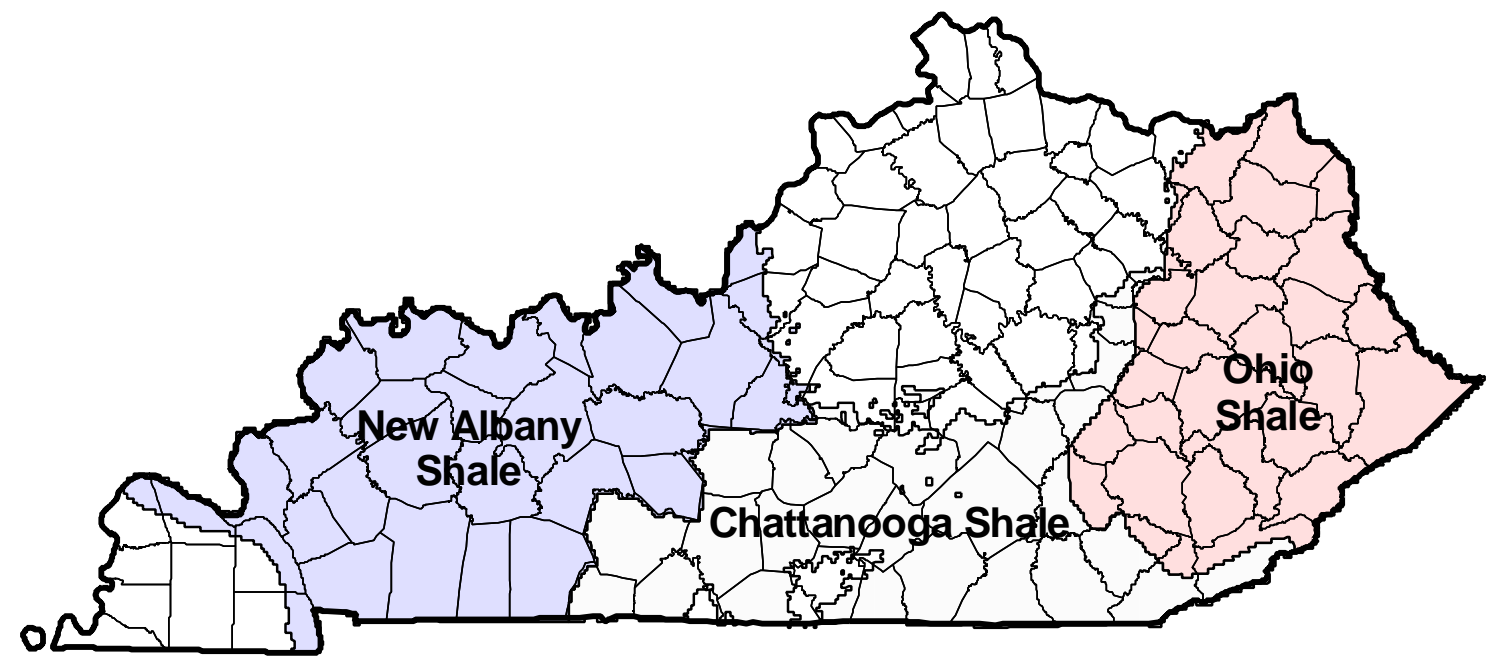

Figure 2. Map showing distribution and nomenclature of Devonian shales of Kentucky (HamiltonSmith, 1993, p. 3)

\section{Experimental}

1) The sampling protocol was modified to eliminate washing and air-drying of drill cuttings. Washing the samples resulted in the loss of too much material. In one case, a substitute for a selected well had to be chosen because insufficient material was available for sampling after washing. Eliminating air drying of the samples saves about one week per each well sampled.

2) Unwashed sets of recently acquired drill cuttings have been identified. These samples are being sorted and processed to place them in permanent storage bags and boxes.

3) The well sample data spreadsheet has been matched to the main oil and gas well record database in order to compile a GIS coverage of these data (Figure 4). GIS was used to select wells that best represent a uniform coverage of the study area and provide information useful for targeting the area to be sampled by sidewall coring.

4) The Columbia Natural Resources No. 24752 Elk Horn Coal, Carter coordinate 11-K-81, Knott County, eastern Kentucky, was logged and 10 sidewall cores through the Devonian shale section were obtained.

5) Samples have been submitted for $x$-ray diffraction analysis to better characterize mineralogy of the shale.

\section{Results and Discussion}

Distribution and stratigraphy of the Devonian shale in eastern Kentucky suggest dividing well cuttings into up to three samples for adsorption analysis. The upper part of the shale from the Cleveland Member to the Middle Huron ("341OHIOU") is generally less organic-rich as indicated by the gamma-ray response on standard geophysical well logs (Figure 3). Drill cuttings of this sequence generally have a lighter gray color and more recognizable quartz material than the darker gray to black samples with sparse pyrite that are characteristic of the Lower Huron Member ("341HURNL"). In some areas of the Big Sandy Gas Field, the Olentangy and Rhinestreet members of the Ohio shale ("341OHIOL") are present but have a somewhat lesser organic content. Where present, these shales will be composited as a separate 
sample. Some wells have an insufficient volume of cuttings available to analyze the individual members of the Ohio shale; these composite samples are designated "341OHIO."

A database of candidate Devonian shale wells for sampling was compiled. Kentucky statutes [KRS 353.660(2)] provide the Survey with the right to request well samples. In anticipation of this project, samples were requested for proposed Devonian shale penetrations in eastern Kentucky. Paper records of well samples received were requested from staff of the well cuttings and cores repository and entered into an Excel spreadsheet. A total of 595 candidate wells have been identified (Figure 4). Geophysical logs from these wells are being scanned to assist in stratigraphic interpretation. A GIS will be used to select wells that best represent a uniform coverage of the study area and provide information useful for targeting the area to be sampled by sidewall coring in year 2 .

While processing unwashed and cataloged drill cuttings at the Well Sample and Core Library, several pallets of recently received, unwashed, but uncataloged, cuttings were located. These drill cuttings have been identified and incorporated into the GIS for sampling.

The distribution of wells initially selected for sampling is illustrated in Figure 5. A list of these wells is provided in Table 1. Due to limitations on the availability, condition, and quantity of cuttings available not all wells will be sampled and other wells may be substituted. 
Table 1. Initial selection of candidate wells to sample for the Devonian Shale $\mathrm{CO}_{2}$ Sequestration project.

\begin{tabular}{|c|c|c|c|c|c|c|c|c|c|}
\hline PERMIT & OPERATOR & WELL & FARM_NAME & COUNTY & SEC & LTR & NUM & TOTAL & TDFM \\
\hline 84653 & ASHLAND EXPLORATION, INC & 60 & FORD MOTOR COMPANY & Pike & 19 & $M$ & 88 & 6130 & 361SQTC \\
\hline 90973 & BRADLEY, CHARLES R DBA BASIN ENE & 1 & NORDMAN, EARLENE & Magoffin & 1 & $\mathrm{O}$ & 79 & 2390 & 357CBOC \\
\hline 91129 & KINZER, J W & 1003 & PIKE LETCHER LAND CO & Letcher & 4 & I & 81 & 3814 & $341 \mathrm{OHIO}$ \\
\hline 91151 & EQUITABLE PRODUCTION COMPANY & KF-4448 & EQUITABLE PRODUCTION CO & Floyd & 25 & $\mathrm{~K}$ & 83 & 3964 & 341OLNG \\
\hline 91182 & EQUITABLE PRODUCTION COMPANY & KL4390 & HOPKINS, JC \& VALENTINE & Floyd & 4 & $\mathrm{~N}$ & 82 & 2358 & 341OLNG \\
\hline 91355 & KINZER, J W & 1052 & KINZER, J W & Pike & 20 & $M$ & 90 & 5199 & 347HDBG \\
\hline 91796 & PENN-VIRGINIA OIL \& GAS CORP & 11 & KENTENIA & Harlan & 7 & $\mathrm{D}$ & 73 & 4327 & 361ODVCU \\
\hline 92640 & EQUITABLE PRODUCTION COMPANY & KL4-504695 & LOWE, A HEIRS & Pike & 20 & $\mathrm{~N}$ & 84 & 3639 & 341OLNG \\
\hline 92647 & ENERGY ASSOCIATES, INC & 1 & ASHER, IDA ET AL & Clay & 8 & $G$ & 72 & 2755 & 357CLNT \\
\hline 92715 & COLUMBIA NATURAL RES, INC & 24526 & BUSH, JOHN ET AL & Floyd & 9 & L & 83 & 3268 & $341 \mathrm{OHIO}$ \\
\hline 93241 & EQUITABLE PRODUCTION COMPANY & 505045 & EVANS, E J & Knott & 12 & L & 79 & 2770 & 341HURNL \\
\hline 93411 & EQUITABLE PRODUCTION COMPANY & 505040 & EQUITABLE PRODUCTION COMPANY & Breathitt & 7 & M & 78 & 2760 & 341OLNG \\
\hline 93453 & EQUITABLE PRODUCTION COMPANY & 504725 & EQUITABLE PRODUCTION CO & Knott & 11 & 1 & 78 & 3550 & 341OLNG \\
\hline 93520 & EQUITABLE PRODUCTION COMPANY & 504984 & EQUITABLE PRODUCTION CO & Knott & 9 & $\mathrm{~J}$ & 77 & 3682 & 341OLNG \\
\hline 93560 & EQUITABLE PRODUCTION COMPANY & 504384 & THE ELK HORN COAL CORP & Floyd & 22 & $M$ & 81 & 2510 & 341OLNG \\
\hline 93762 & C D \& G ENT - JOHNSON, GARY C & 1 & MCGINNIS, BASIL ET AL & Martin & 19 & $\mathrm{P}$ & 83 & 2879 & $341 \mathrm{OHIO}$ \\
\hline 93844 & BRADLEY, CHARLES R DBA BASIN ENE & 1 & RIDDLE, TROY & Perry & 6 & G & 78 & 3905 & $341 \mathrm{OHIO}$ \\
\hline 94045 & COLUMBIA NATURAL RES, INC & 24875 & KENTUCKY BERWIND LAND CO & Pike & 14 & $\mathrm{~K}$ & 87 & 4975 & $341 \mathrm{OHIO}$ \\
\hline 94086 & INTERSTATE NATURAL GAS CO & 4 & DAVIS, IDA & Knott & 24 & $\mathrm{~K}$ & 81 & 3190 & $341 \mathrm{OHIO}$ \\
\hline 94088 & EQUITABLE PRODUCTION COMPANY & 505313 & EQUITABLE PRODUCTION CO & Pike & 16 & $\mathrm{~K}$ & 86 & 4182 & 341OLNG \\
\hline 94107 & EQUITABLE PRODUCTION COMPANY & 505333 & EQUITABLE PRODUCTION CO & Pike & 14 & L & 86 & 4360 & 341OLNG \\
\hline 94174 & COLUMBIA NATURAL RES, INC & 23798 & HAYS, LUTITIA ET AL & Knott & 8 & $\mathrm{~J}$ & 79 & 3256 & $341 \mathrm{OHIO}$ \\
\hline 94175 & EQUITABLE PRODUCTION COMPANY & 504790 & TIERNEY, LAWRENCE E & Pike & 19 & $\mathrm{~N}$ & 86 & 4150 & 341OLNG \\
\hline 94210 & EQUITABLE PRODUCTION COMPANY & 565386 & EQUITABLE PRODUCTION CO & Pike & 13 & $\mathrm{~J}$ & 84 & 4620 & 341OLNG \\
\hline 94229 & COLUMBIA NATURAL RES, INC & 24945 & THE ELK HORN COAL CORP / HUNT & Floyd & 4 & L & 83 & 3126 & $341 \mathrm{OHIO}$ \\
\hline
\end{tabular}




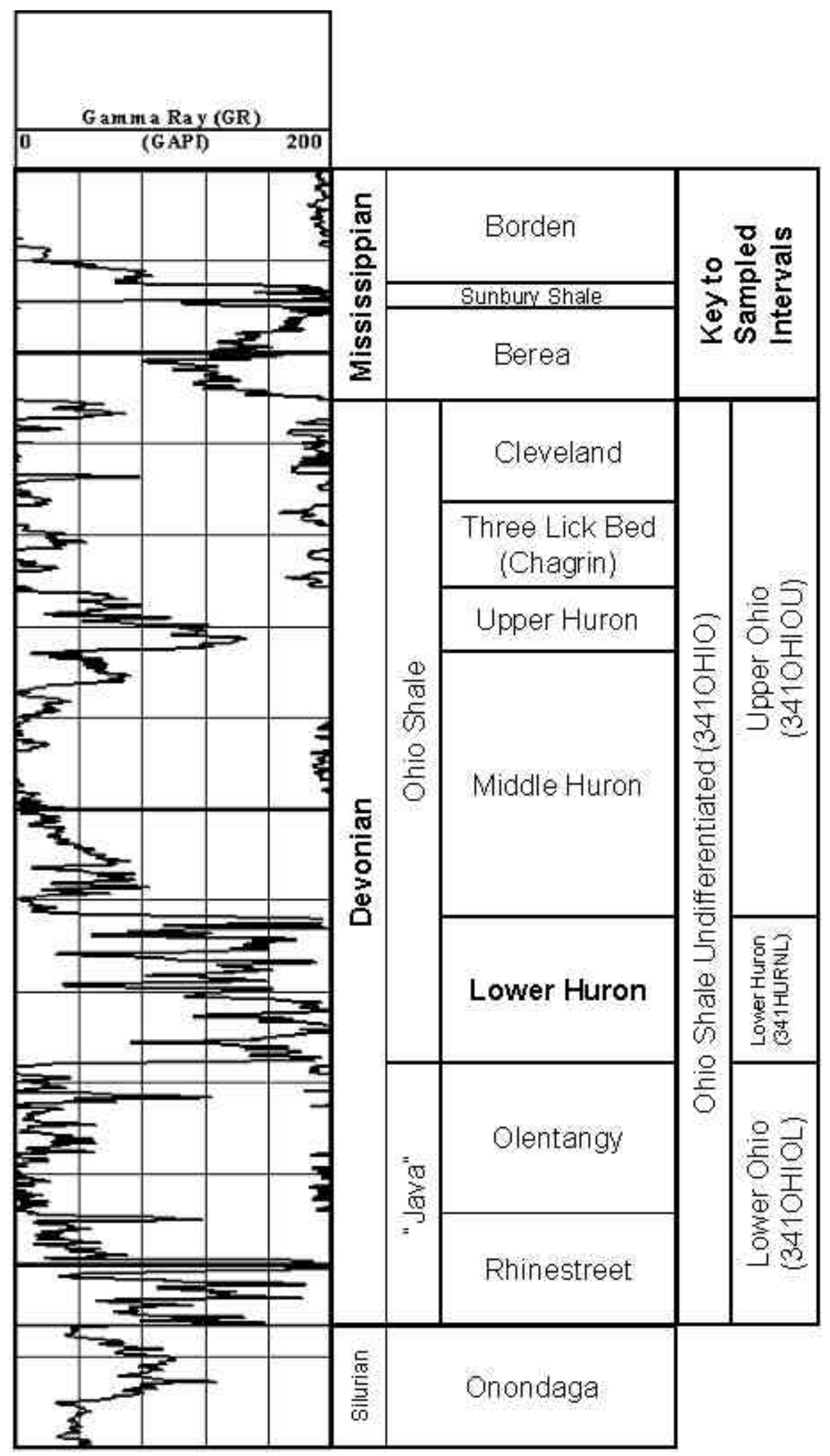

Figure 3. Nomenclature of Mississippian and Devonian shales of eastern Kentucky and key to names and codes used for intervals sampled. 


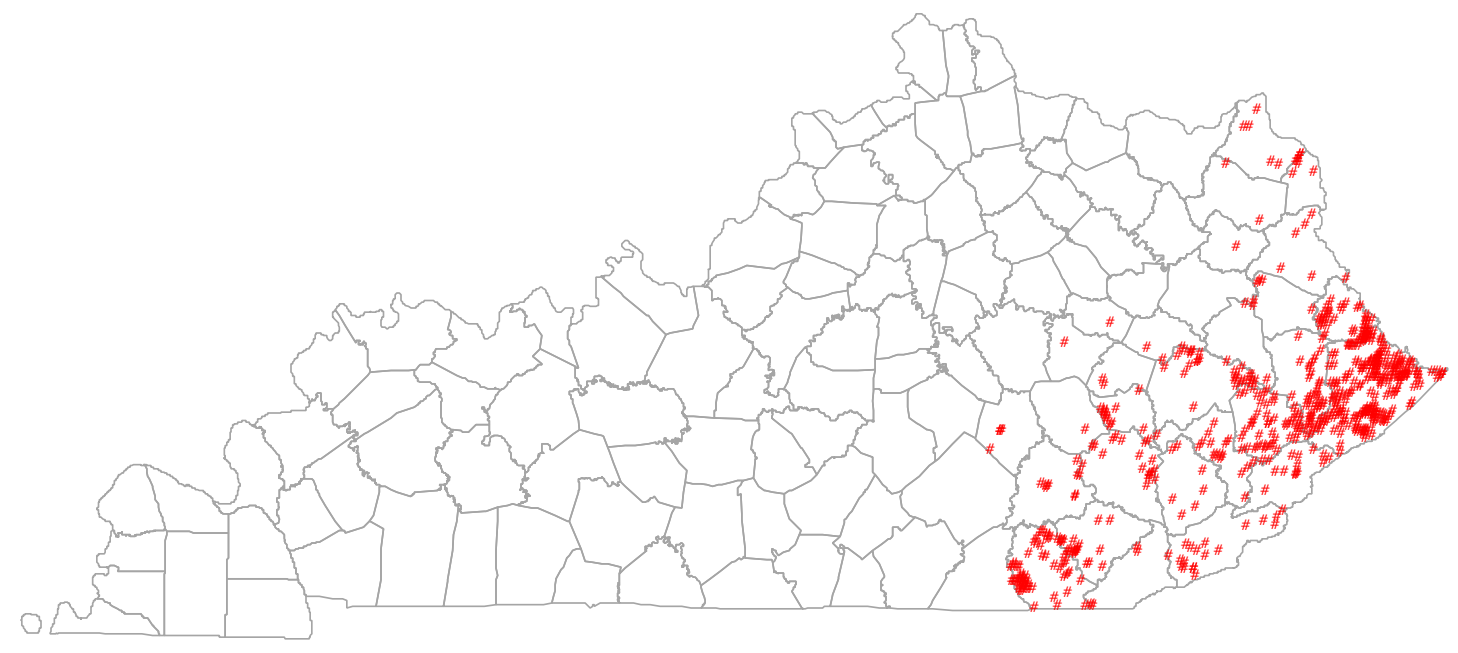

Figure 4. Initial distribution of Devonian shale drill cuttings sample sets.

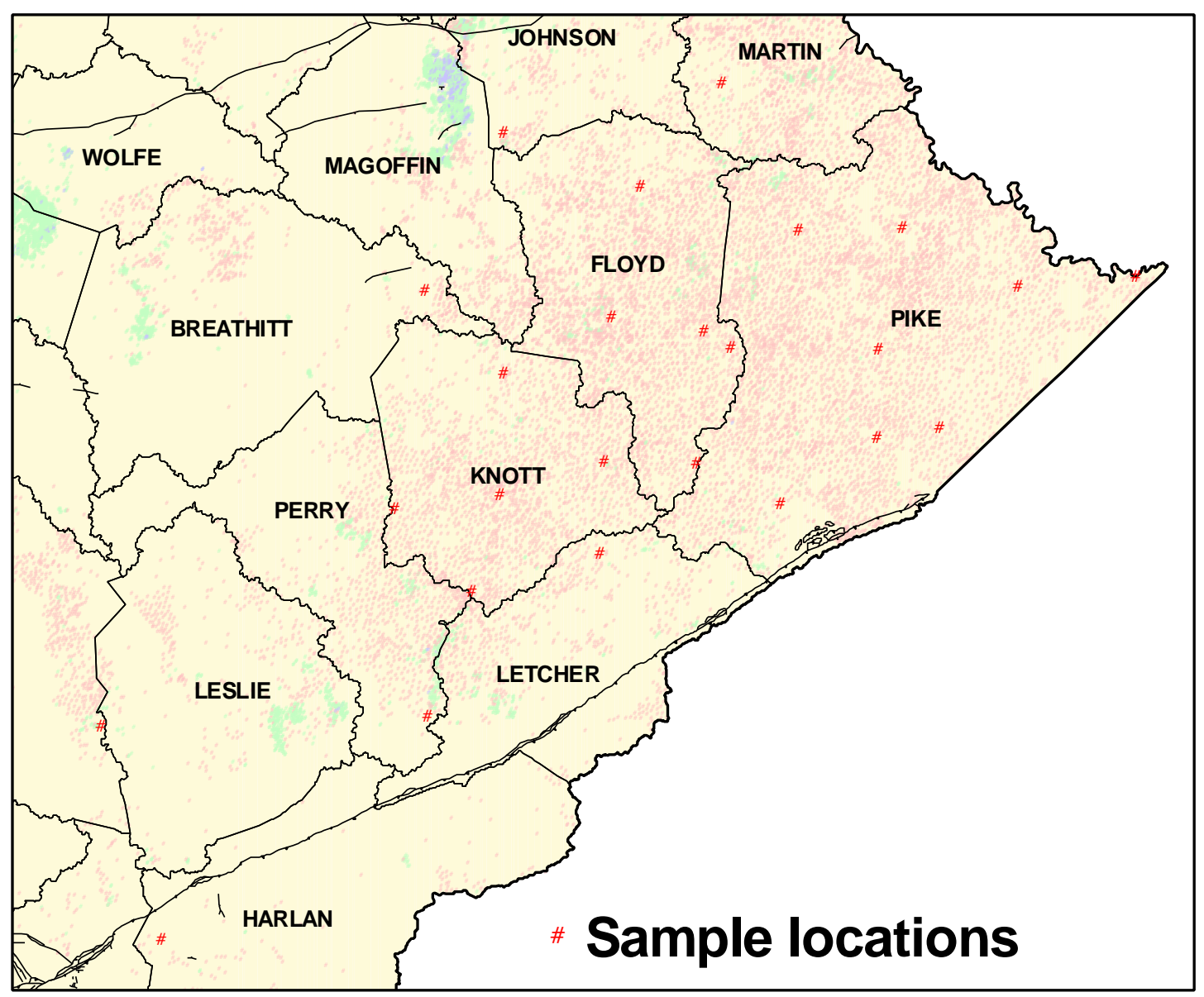

Figure 5. Eastern Kentucky Devonian Shale CO2 Sequestration sample locations. 
The Kentucky Well Sample and Core Library is a facility housing a legacy data set of subsurface information for the Commonwealth. Drill cuttings are received at the warehouse, cataloged, and shelved while awaiting processing. Sample bags are identified by well and depth information and roughly sorted. The contents of each bag are emptied into a 160 mesh copper sieve with a serial identifier. For each sample bag, a sample label is prepared with the sieve number, footage, and catalogue number. This label is mounted on a plastic insert that will become a permanent part of the sample collection. Once loaded into the sieves, the samples are placed on a tray and run through a conveyor driven sample washer. For this project, the drying oven is turned off and all samples are air-dried. After drying, the plastic identifying tags are matched to the sieves. The tag and cuttings are stored together in a self-sealing polyethylene bag. The identified bags are then sorted by depth and loaded into corrugated boxes for storage in the library.

For this project, the intervals to be sampled are identified from the drillers' logs and geophysical logs on file (see Figure 4 for a type log). For those wells with sufficient material, composite samples will be collected for the Upper Ohio shale (Cleveland through Middle Huron Members), the Lower Huron Member, and the Lower Ohio shale (Olentangy and Rhinestreet if present). Equal amounts of cuttings from each 10-foot interval as collected by drillers are incorporated into the composite sample for adsorption and petrographic analysis. If there are multiple sample bags for the same interval, only one bag is sampled. The composite samples are mixed and split into fractions as required for each procedure.

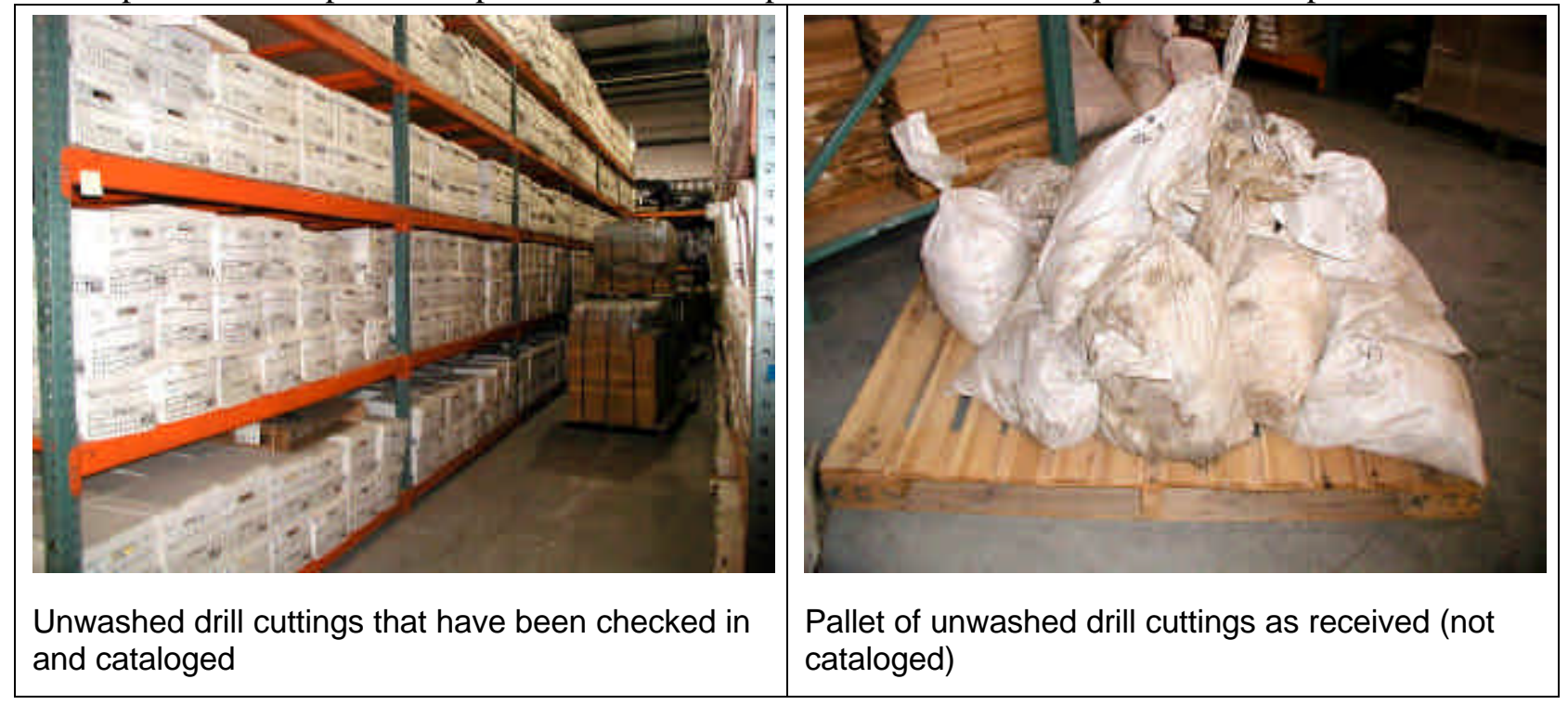




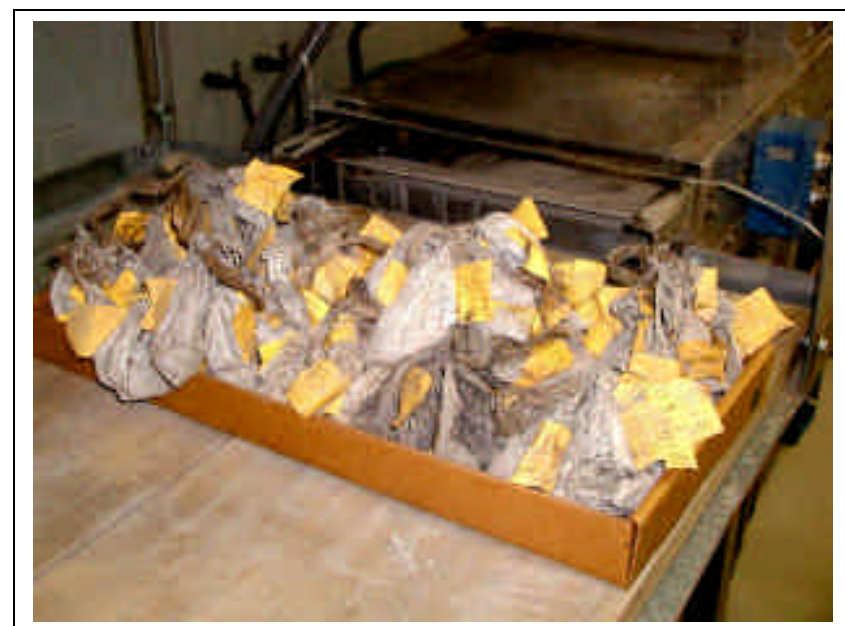

Drill cuttings readied for sorting and processing.

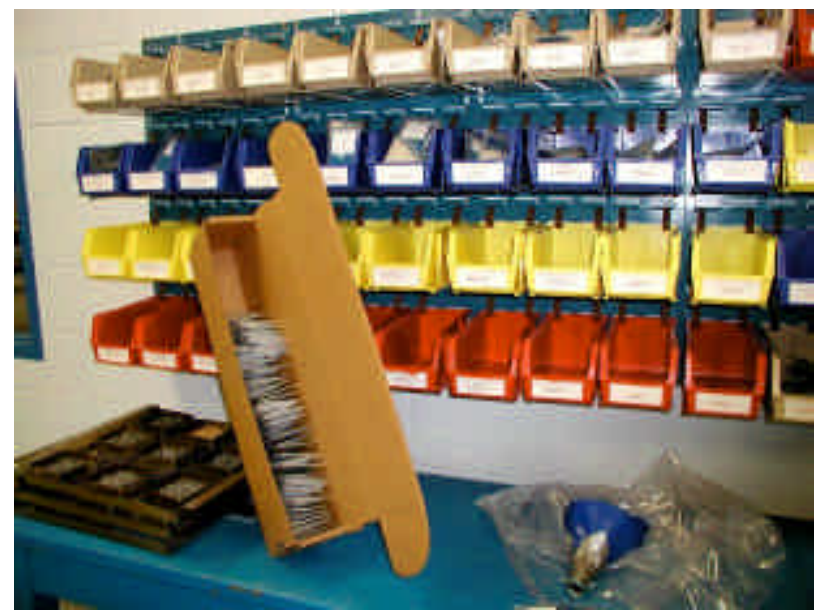

Sorted drill cuttings are packed into individual bags

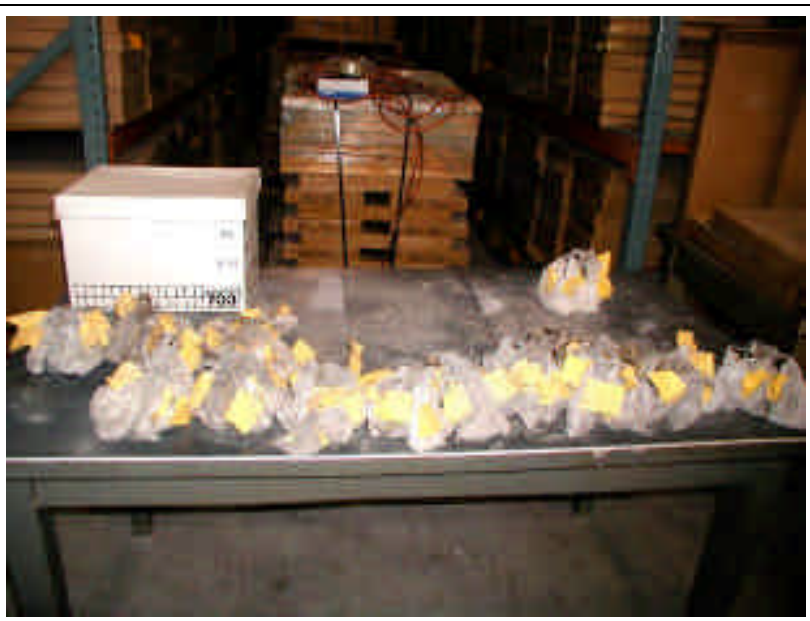

Sorting samples in preparation for loading into polyethelyene sample bags.

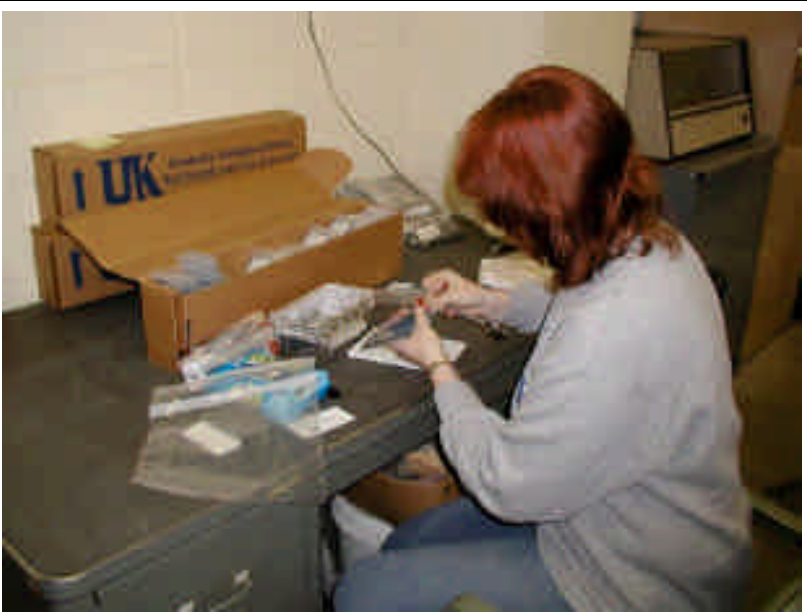

Leah Barth collecting composite sample for $\mathrm{CO}_{2}$ adsorption and petrographic analyses 


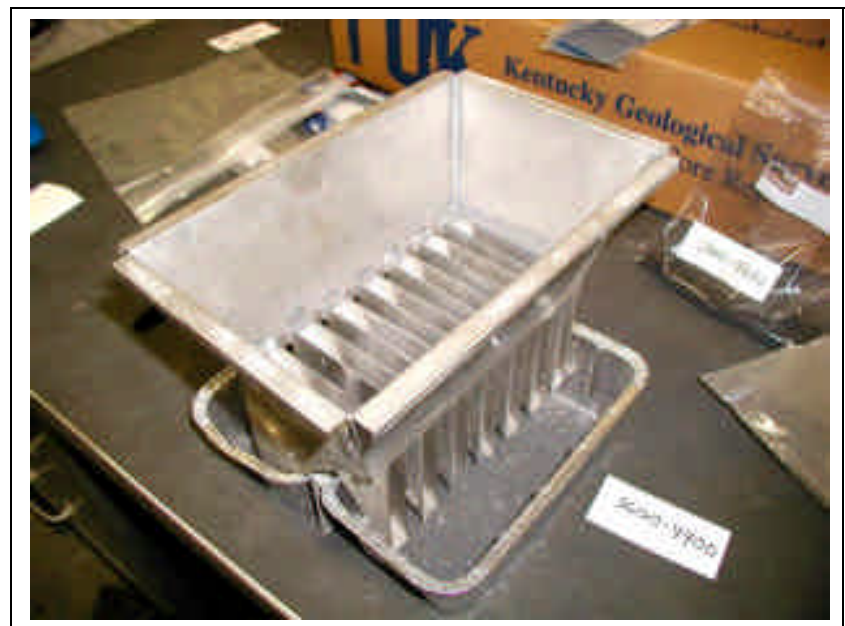

Splitting composite sample for petrographic and adsorption analyses

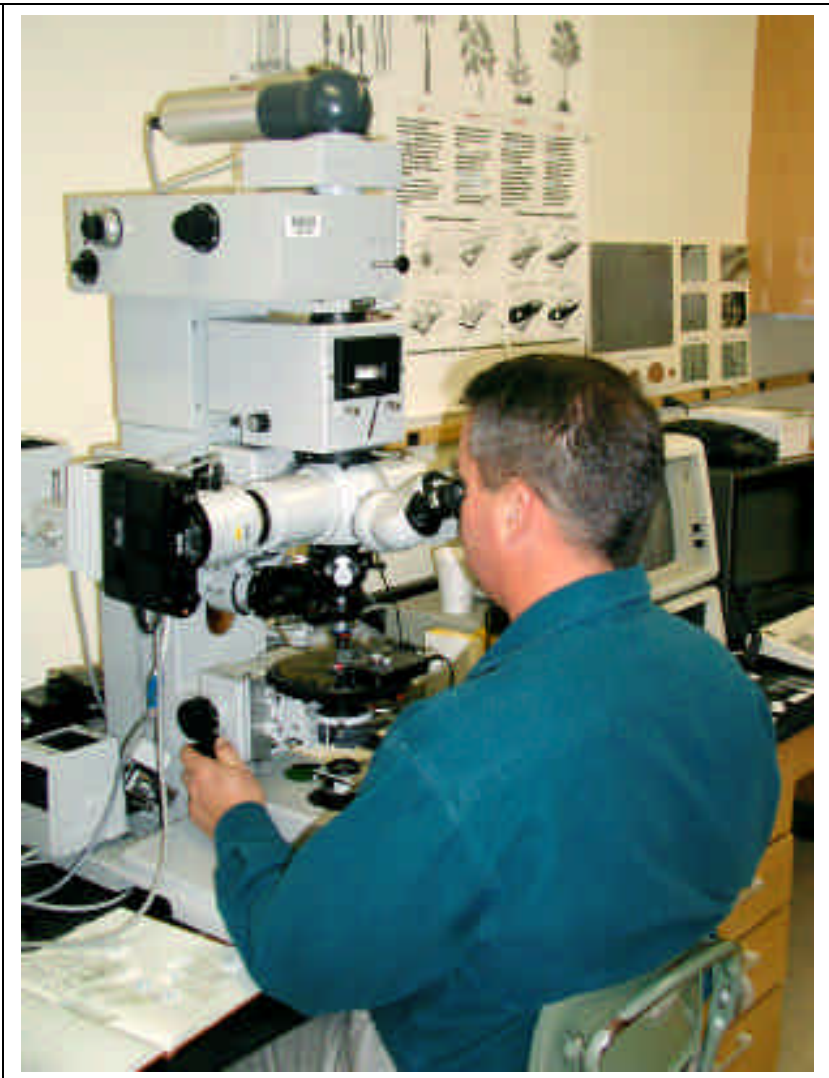

Cortland Eble examining samples for petrographic analysis 


\section{Total Organic Carbon}

Table 2. Gas storage capacity, TOC, and vitrinite reflectance data for completed samples

\begin{tabular}{|c|c|c|c|c|c|c|}
\hline \multirow[b]{2}{*}{ Sample } & \multirow[b]{2}{*}{ Formation } & \multicolumn{2}{|c|}{ Reported } & \multirow[b]{2}{*}{$\begin{array}{l}\text { TC as } \\
\text { rec'd }\end{array}$} & \multirow[b]{2}{*}{$\begin{array}{l}\text { TOC } \\
\left(\operatorname{acid}^{\star}\right)\end{array}$} & \multirow[b]{2}{*}{$\mathbf{R}_{\text {Orandom }}$} \\
\hline & & $\underset{\text { scf/ton }}{\mathrm{CO}_{2}}$ & $\begin{array}{l}\mathrm{CO}_{2} \\
\text { psia }\end{array}$ & & & \\
\hline 107928-1 & Upper Ohio & 37.5 & 681.1 & 1.67 & 0.69 & 1.55 \\
\hline 107928-2 & Lower Huron & 67.6 & 243.7 & 3.94 & 2.95 & 1.48 \\
\hline 107928-3 & Lower Ohio & 34.6 & 253.1 & 3.55 & 1.60 & 1.59 \\
\hline 121774-1 & Ohio Shale & 126.5 & 989.8 & 6.15 & 3.66 & 1.10 \\
\hline 124789-1 & Upper Ohio & 740.8 & 6419.1 & 4.41 & 3.26 & 0.78 \\
\hline $124789-2$ & Lower Huron & 2077.6 & 14283.5 & 5.69 & 4.62 & 0.81 \\
\hline 124789-3 & Lower Ohio & 116.2 & 957.9 & 3.27 & 1.78 & 0.83 \\
\hline 123486-1 & Upper Ohio & 228.9 & 2230.4 & 3.64 & 2.44 & 0.78 \\
\hline 123486-2 & Lower Ohio & 309.3 & 2106.0 & 5.00 & 4.13 & 0.82 \\
\hline 121162-1 & Ohio Shale & 164.2 & 1561.3 & 2.51 & 2.37 & 0.85 \\
\hline 121464-1 & Upper Ohio & 52.6 & 708.9 & 1.33 & 1.18 & 1.52 \\
\hline $121464-2$ & Lower Huron & 248.7 & 751.2 & 4.21 & 3.60 & 1.52 \\
\hline $121464-3$ & Lower Ohio & 108 & 819 & 2.81 & 2.31 & 1.51 \\
\hline
\end{tabular}

For total organic carbon analyses, samples were first crushed to a maximum particle size of 200 microns (-60 mesh). 3 to $4 \mathrm{~g}$ of sample were then placed in $100 \mathrm{ml}$ beakers and then covered (slowly) with concentrated $(30 \%)$ hydrochloric acid to remove any carbonate minerals that might be present. The samples were left in acid for 2 to 3 days, occasionally being stirred. The hydrochloric acid was removed by repeated washings with distilled water, followed by centrifugation. The samples were then placed in a drying oven (50 degrees $\mathrm{C}$ ).

Total organic carbon was measured on a LECO® SC-144 DR dual range sulfur and carbon analyzer, which is a non-dispersive, infrared, digitally-controlled instrument designed to measure sulfur and carbon in a wide variety of organic and inorganic materials. The unit combusts samples in a pure oxygen environment at $1350^{\circ} \mathrm{C}$. Sulfur compounds are immediately oxidized and form sulfur dioxide $\left(\mathrm{SO}_{2}\right)$; carbon compounds are oxidized to carbon dioxide. From the combustion system, sample gases pass through two tubes containing magnesium perchlorate $\left(\mathrm{MgClO}_{4}\right)$ which removes moisture, and then are routed to the infrared (IR) detection cells. A sulfur IR cell measures the amount of $\mathrm{SO}_{2}$ present in the gas stream, and a carbon IR cell does the same for $\mathrm{CO}_{2}$. All molecules, with the exception of bipolar species (e.g. $\mathrm{N}_{2}, \mathrm{H}_{2}, \mathrm{O}_{2}$ ), absorb energy in the infrared region. As radiant energy is projected through the sample material an IR absorption spectrum is produced. Since no two molecules produce the same spectrum, the identity and quantity of a compound can be readily, and accurately, determined.

Samples were run in duplicate. One split was run "as is". Another split was treated with $30 \%$ hydrochloric acid $(\mathrm{HCl})$ for 12 to 24 hours to remove any carbonate minerals from the matrix, prior to instrumental testing. Although carbonate minerals are typically a rare component of Devonian shales, they present a possible bias in the calculation of TOC, because like organic material, they dissociate in the combustion chamber and form $\mathrm{CO} 2$. The results thus far indicate a 0.5 to $1.0 \%$ difference between the treated and non-treated samples.

Well samples with completed analyses are shown in Table 2. 


\section{Reflectance Analyses}

Mean random reflectance (Ro random) on dispersed vitrinite particles in the samples was determined on a Zeiss@ USMP incident light microscope calibrated using glass standards of known reflectance.

Depending on the amount of vitrinite in the samples, 50 or 100 grains were measured at a magnification of $640 \mathrm{X}$ to determine mean reflectance. Mean random reflectance was used because it eliminates the need to rotate the stage to determine maximum and minimum reflectance values. As the vitrinite particles in the analyzed samples were quite small (usually < 10 microns), stage rotation simply wasn't practical, as it often resulted in the reflectance measuring spot moving off the grain. Maximum vitrinite reflectance values (Romax) can be estimated by multiplying the mean random measurements by 1.066 (Ting, 1978).

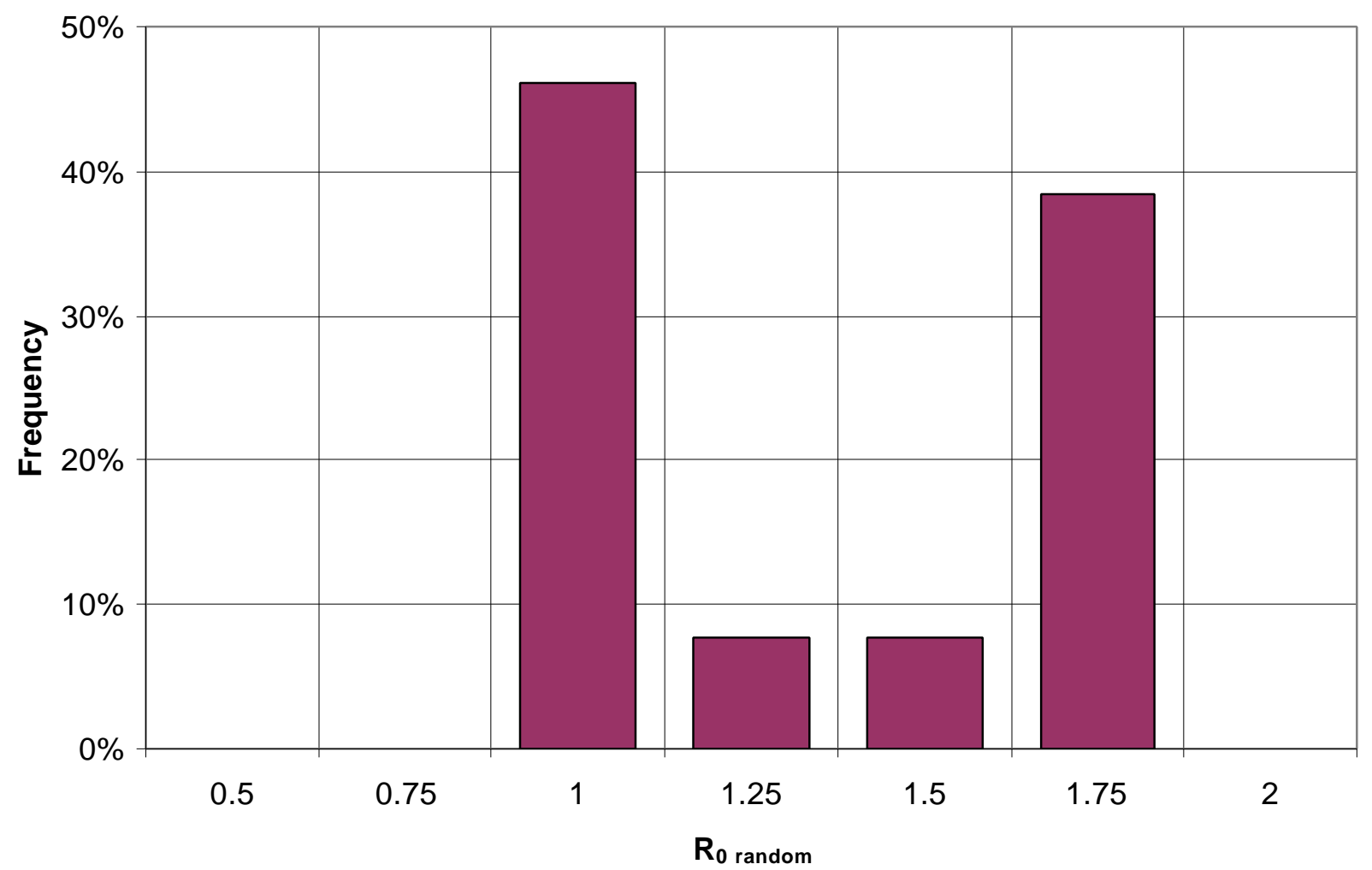

Figure 6. Mean random reflectance $\left(\mathbf{R}_{0}\right.$ random $)$

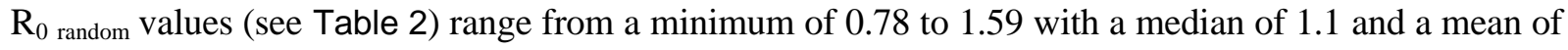
1.2. This places the shale in the upper oil to wet gas and condensate maturity range as measured by reflectance. In Figure 6, axis labels refer to the upper (right) end of the graphed class.

\section{Drilling}

Columbia Natural Resources (CNR, now owned by Triana) drills a number of Devonian shale gas wells in eastern Kentucky as a normal part of their resource development program. A drill hole of opportunity was identified and sidewall cores and logs were obtained from the well. An electron capture spectroscopy (ECS) log will be obtained to investigate the correlation of any mineral associations with $\mathrm{CO}_{2}$ adsorption capacity. The cores have been submitted for laboratory analysis by saturation with $\mathrm{CH}_{4}$ and analysis of $\mathrm{CH}_{4}$ displacement efficiency as $\mathrm{CO}_{2}$ is injected into the core. Contacts were established with Jay Terry of Schlumberger Oilfield Services to obtain sidewall coring and ECS logging services. Junior Jenkins (formerly) and Ed Rothman of CNR were contacted. The CNR well number 24752 Elk Horn Coal Company is located in eastern Knott County (Figure 7). 


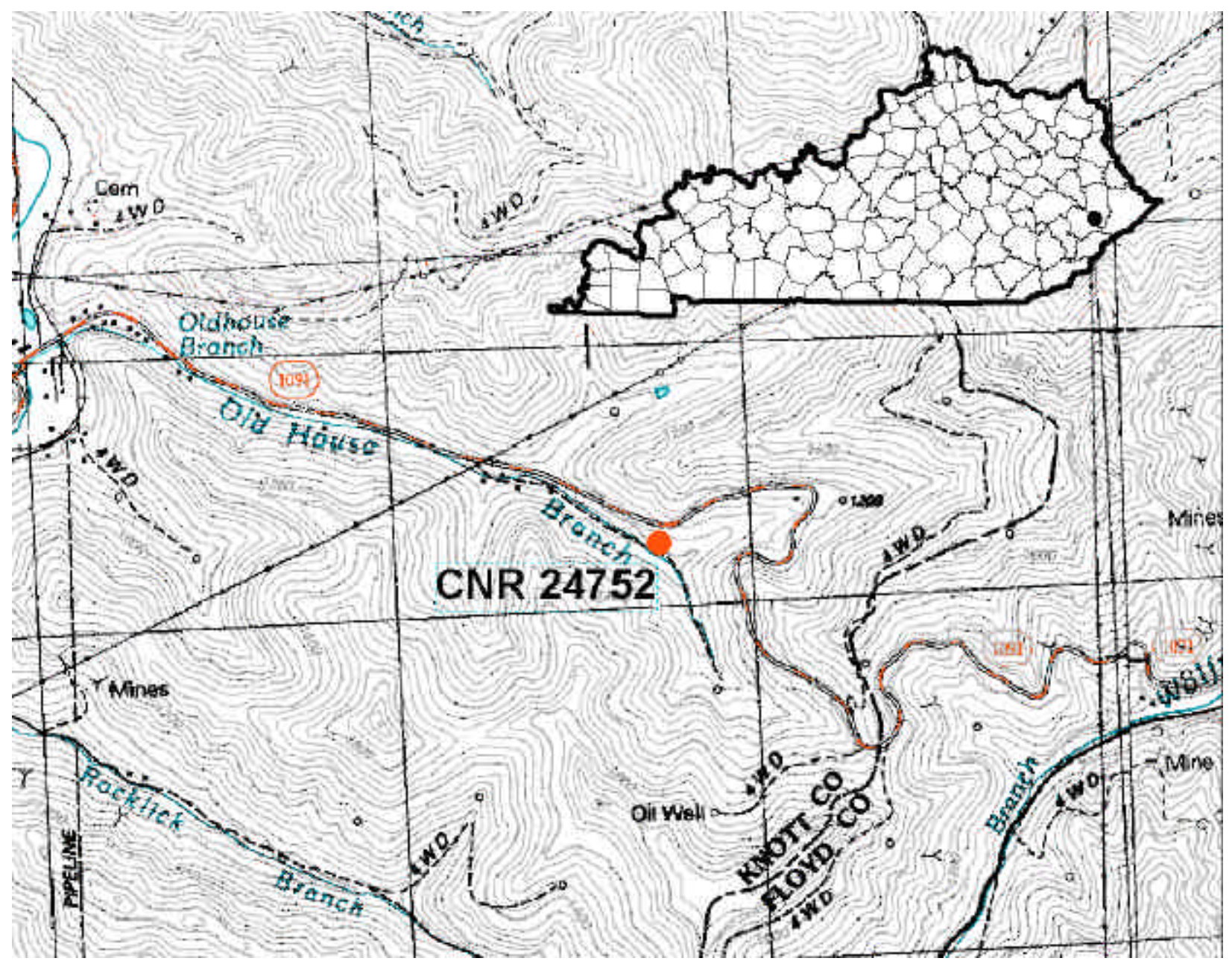

Figure 7. Location of the Columbia Natural Resources 24752 Elk Horn Coal Company well, permit 94539, Knott County, Kentucky Carter coordinate 11-K-81, latitude 37.37019 № , longitude 82.76441으 W (NAD 1983).

Ten sidewall cores were recovered and are summarized in Appendix C. Of these cores, 7 were intact and have been submitted for $\mathrm{CO}_{2}$ adsorption and methane displacement analysis. The three broken cores are being analyzed for solvent extraction for chromatographic analysis identify any light hydrocarbons present and for petrographic analysis. Appendix $\mathrm{C}$ also includes sections of the litho-density and elemental capture spectroscopy logs acquired.

\section{$\mathrm{CO}_{2}$ Adsorption Isotherms}

Adsorption isotherms for these samples are summarized in Figure 8 and presented in Appendix A. Several samples exhibit unexpectedly high measured values for the adsorbed volume of $\mathrm{CO}_{2}$. Additionally, the adsorption isotherms for these samples do not exhibit the expected inflection point representative of reaching a saturated monolayer of adsorbant (the Langmuir volume). At this time, the cause of these suspected anomalies is unknown; the samples are being re-processed to verify the experimental procedures and results. 
Figure 8. Summary of adsorption isotherms by formation

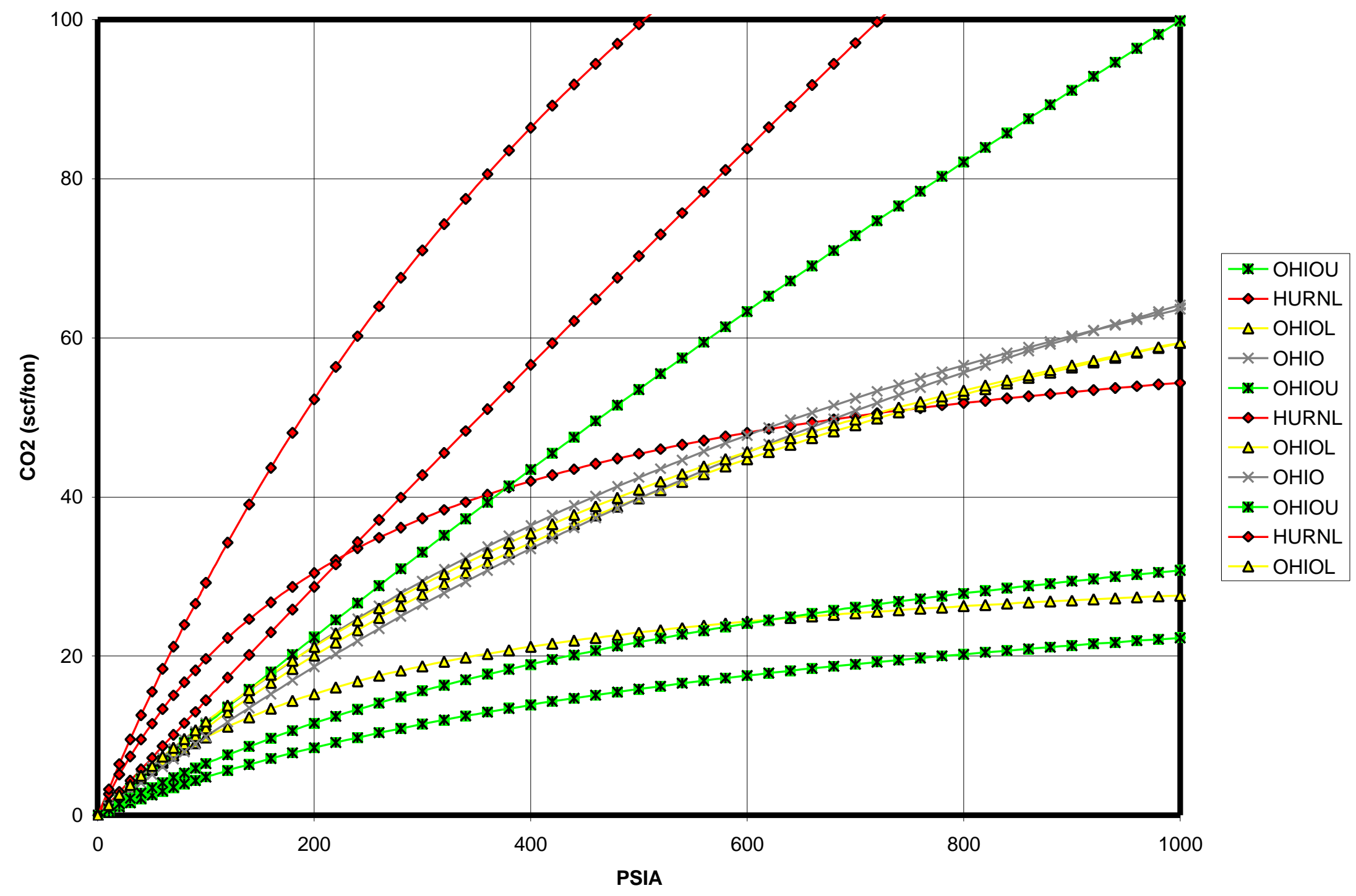


To effectively compare capacity data derived from adsorption isotherms, three pressure conditions have been selected: 300, 400, and 500 psia. These comparison data are presented in Table 3.

Table 3. Summary of $\mathrm{CO}_{2}$ adsorption capacity in standard cubic feet per ton at selected pressures.

\begin{tabular}{|l|l|r|r|r|}
\hline \multirow{2}{*}{ Sample } & \multicolumn{1}{|c|}{ FM } & \multicolumn{3}{|c|}{ PSIA } \\
\cline { 3 - 5 } & & $\mathbf{3 0 0}$ & $\mathbf{4 0 0}$ & $\mathbf{5 0 0}$ \\
\hline $121162-1$ & Ohio Shale & 26.5 & 33.5 & 39.8 \\
\hline $121774-1$ & Ohio Shale & 29.4 & 36.4 & 42.5 \\
\hline Average & $\begin{array}{l}\text { Ohio Shale } \\
\text { Undifferentiated }\end{array}$ & $\mathbf{2 7 . 9}$ & $\mathbf{3 4 . 9}$ & $\mathbf{4 1 . 1}$ \\
\hline $107928-1$ & Upper Ohio & 11.5 & 13.9 & 15.9 \\
\hline $121464-1$ & Upper Ohio & 15.6 & 19 & 21.8 \\
\hline $124789-1$ & Upper Ohio & 33.1 & 43.5 & 53.5 \\
\hline Average & Upper Ohio Shale & $\mathbf{2 0 . 1}$ & $\mathbf{2 5 . 4}$ & $\mathbf{3 0 . 4}$ \\
\hline $107928-2$ & Lower Huron & 37.3 & 42 & 45.4 \\
\hline $121464-2$ & Lower Huron & 71 & 86.4 & 99.4 \\
\hline $124789-2$ & Lower Huron & 42.7 & 56.6 & 70.3 \\
\hline Average & Lower Huron & $\mathbf{5 0 . 3}$ & $\mathbf{6 1 . 7}$ & $\mathbf{7 1 . 7}$ \\
\hline $107928-3$ & Lower Ohio & 18.8 & 21.2 & 23 \\
\hline $121464-3$ & Lower Ohio & 29 & 35.4 & 40.9 \\
\hline $124789-3$ & Lower Ohio & 27.7 & 34.2 & 39.9 \\
\hline Average & Lower Ohio Shale & $\mathbf{2 5 . 1}$ & $\mathbf{3 0 . 3}$ & $\mathbf{3 4 . 6}$ \\
\hline Average & Overall & $\mathbf{3 1 . 1}$ & $\mathbf{3 8 . 4}$ & $\mathbf{4 4 . 8}$ \\
\hline
\end{tabular}

The averages from Table 3 when presented graphically, Figure 9, clearly show the Lower Huron (HURNL) to have the greatest sequestration capacity. 


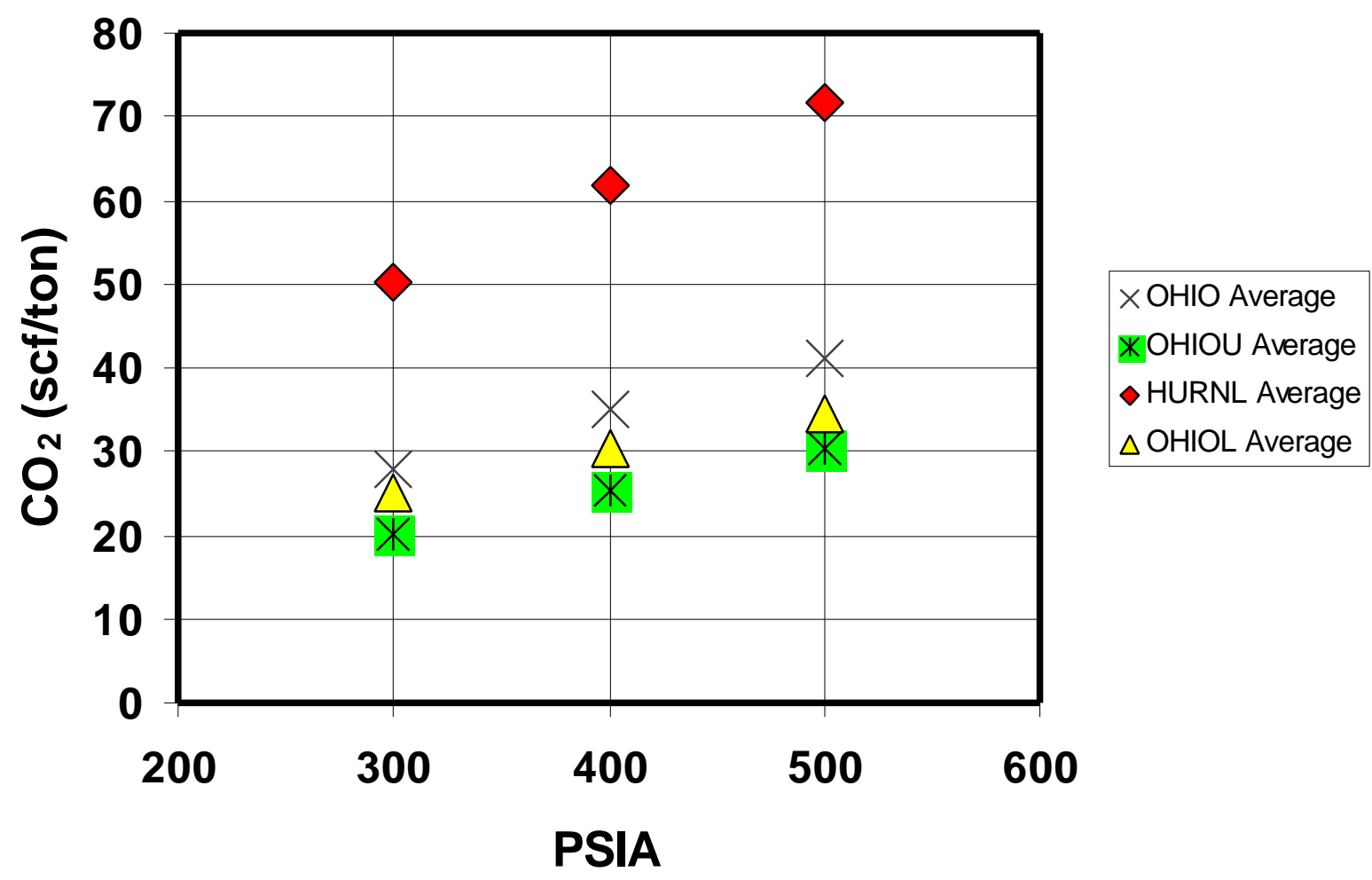

Figure 9. Average calculated adsorption capacities by formation at selected pressures

Initial estimates of $\mathrm{CO}_{2}$ sequestration capacity have been calculated using selected data. An initial estimate of the sequestration volume of the Lower Huron was compiled using areal distribution and thickness data from Dillman and Ettensohn (1980c). Using a Langmuir volume of $67.6 \mathrm{scf} / \mathrm{ft}^{3}$ (raw data from sample 107928-2, Table 2), and an average thickness of 150 feet over the area of Boyd, Breathitt, Floyd, Johnson, Knott, Lawrence, Leslie, Magoffin, Martin, Perry, and Pike Counties combined, initial calculations indicate that $91 \times 10^{12}$ cubic feet of $\mathrm{CO}_{2}$ could be sequestered in the Lower Huron. At 30 percent of this theoretical saturation, approximately 1.6 billion tons of $\mathrm{CO}_{2}$ could be sequestered. A method is needed to extend similar analyses over the area of Kentucky underlain by Devonian shale that allows for variable shale thickness and adsorption capacities.

A procedure has been developed to use geographic information systems software (GIS) to analyze the potential total volume of $\mathrm{CO}_{2}$ sequestration for Kentucky. The method uses a cell-based approach that enables combining shale thickness and depth information in the form of continuous grids with shale density and spatially variable $\mathrm{CO}_{2}$ adsorption capacity data. Using a one-kilometer grid, a depth to top of shale of 1,000 feet or greater, a shale thickness of 50 feet or more, and a constant adsorption capacity equal to a thickness-weighted average of $40 \mathrm{scf} / \mathrm{ft}^{3}$ (raw data from samples 107928-1, 107928-2, and 107928-3, Table 2), estimated initial $\mathrm{CO}_{2}$ sequestration capacity of the Devonian shale in Kentucky is 27.7 billion tons, Figure 10. An additional advantage of this method is that capacity estimates can be calculated for counties or regions. Note that by assuming a single value for gas storage capacity, the resulting estimate is strictly dependent on thickness of the shale. Appendix B presents a discussion of the method and an example summary by county and region of sequestration capacity. The procedure is currently under review. 


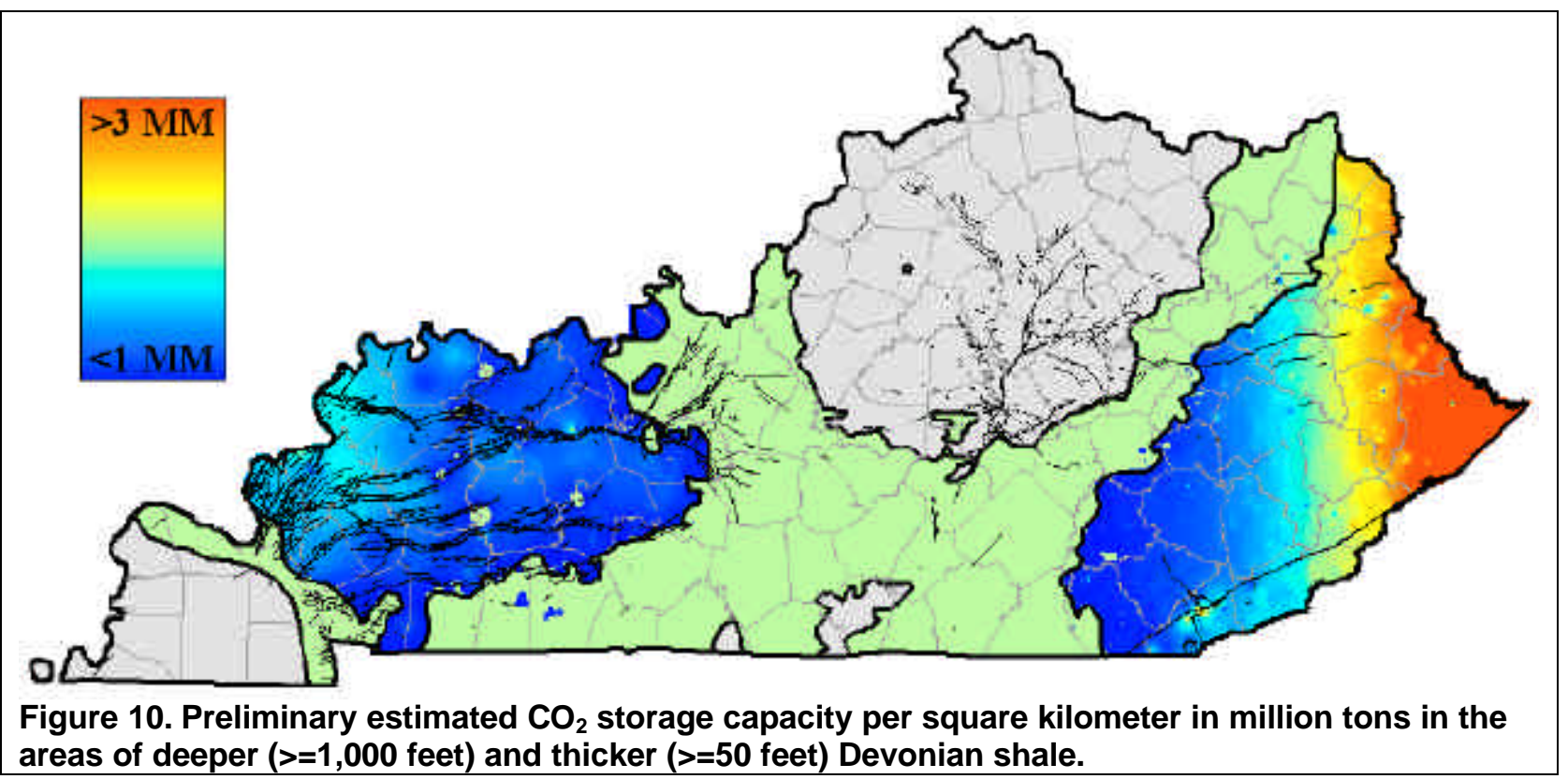

\section{Conclusion}

Collecting drill cuttings for composite sampling is proceeding. Uncatalogued sample sets continue to be identified for possible incorporation into the project. The sampling procedures have been revised to eliminate washing in order to increase the amount of available material in the drill cuttings. Geophysical $\operatorname{logs}$ are being correlated to direct sampling efforts. Sample sets are being delivered to partners for analysis. Columbia Natural Gas (now owned by Triana) has drilled and provided access to a drill hole for logging and sidewall coring. Sidewall cores have been submitted for analysis. Initial adsorption data indicate a potential for $\mathrm{CO}_{2}$ sequestration. Preliminary estimates indicate a storage capacity of 27.7 billion tons of $\mathrm{CO}_{2}$. 


\section{References Cited}

Hamilton-Smith, T., 1993, Gas exploration in the Devonian shales of Kentucky, Kentucky Geological Survey, Series 11, Bulletin 4, 31 p.

Ting, F.T.C., 1978. Petrographic Techniques in Coal Analysis, in Karr, C., Jr. (editor), Analytical Methods for Coal and Coal Products, Academic Press, vol. 1, pp. 3-26.

\section{Bibliography}

1996, $\mathrm{CO}_{2}$ Recovery Not Feasible: Power, v. 140, no. 6, p. 62.

1997, Big Canadian Miscible $\mathrm{CO}_{2}$ EOR Project, Pipeline Advanced: Oil \& Gas Journal, no. 7 July, p. 23 24.

1998, Kansas Fields Screened for $\mathrm{CO}_{2}$ Pilot Program, $\mathrm{CO}_{2}$ Bulletin (Shell $\mathrm{CO}_{2}$ Company, Ltd.).

1999, DOE Eyes Research to Sequester Carbon Dioxide, Oil \& Gas Journal, p. 53-54.

Abelson, P. H., 2000, Future Supplies of Electricity: Science, v. 287, p. 971.

Acomb, B., 1979, The petrology, stratigraphy and origin of phosphatic nodules in Upper Devonian and Lower Mississippian rocks of the eastern interior [Thesis]: University of Cincinnati, unknown $\mathrm{p}$.

Adewusi, V. A., and Ikwuka, N. A., 1998, Tertiary Oil Recovery Potential from $\mathrm{CO}_{2}$-Miscible Flooding of Agbada Viscous Oil Reservoir: Petroleum Science and Technology, v. 16, no. 5\&6, p. 477501 .

Akai, M., Kagajo, T., and Inoue, M., 1995, Performance Evaluation of Fossil Power Plant with $\mathrm{CO}_{2}$ Recovery and a Sequestering System: Energy Conversion and Management, v. 36, no. 6-9, p. 801-804.

Akai, M., Nomura, N., Waku, H., and Inoue, M., 1997, Life-Cycle Analysis of a Fossil-Fuel Power Plant with $\mathrm{CO}_{2}$ Recovery and a Sequestering System: Energy, v. 22, no. 2/3, p. 249-255.

Anderson, L. G., Olsson, K., Jones, E. P., Chierici, M., and Fransson, A., 1998, Anthropogenic carbon dioxide in the Arctic Ocean; inventory and sinks: Journal of Geophysical Research, C, Oceans, v. 103, no. 12, p. 27.

Anonymous, 1996, New Albany shale gas flow starts in western Indiana: Oil and Gas Journal, v. 94, no. 18, p. 69-70.

Arco, N. d., 1981, Regional and local geochemical variation in the Devonian Black shales of Eastern Kentucky [Thesis]: University of Kentucky, unknown p.

Bachu, S., 1999, Geological disposal of carbon dioxide emitted by the upstream energy industry; the potential for the Alberta Basin, in Program and Abstracts of the 1999 Annual Convention American Association of Petroleum Geologists, San Antonio, TX, April 11-14, 1999, p. A8.

Bachu, S., 2000, Sequestration of $\mathrm{CO}_{2}$ in geologic media: criteria and approach for site selection in response to climate change: Energy Conservation and Management, v. 41, no. 9, p. 953-970.

Barden, C., Corlay, P., and Longeron, D., 1991, Interpretation of a $\mathrm{CO}_{2}$ Huff'n'Puff field case in a lightoil-depleted reservoir: SPE 22650, p. 551-562.

Barnett, S. F., 1995, The Portwood Member (upper Middle Devonian) of the New Albany shale of central Kentucky; nature and origin [PhD Dissertation thesis]: University of Kentucky, 545 p. 
Barnett, S. F., and Ettensohn, F. R., 1992, Portwood Member of the New Albany shale and the Boyle Dolostone, in Ettensohn, F. R., Barnett, S. F., Greb, S. F., Chesnut, D. R., Jr., Lierman, R., Eble, C. F., Mason, C. E., Pasin, J. C., Goodmann, P. T., and Schumacher, G. A., eds., Changing interpretations of Kentucky geology; layer-cake, facies, flexure, and eustacy: Miscellaneous Report-Ohio, Division of Geological Survey, p. 42-44.

Barnett, S. F., Ettensohn, F. R., and Norby, R. D., 1995, The Carpenter Fork Bed, a new- and olderblack-shale unit at the base of the New Albany shale in central Kentucky; characterization and significance: Southeastern Geology, v. 35, no. 4, p. 187-210.

Barron, L. S., 1982, The paleoecology of the Upper Devonian-Lower Mississippian black shale sequence in Eastern Kentucky [Thesis thesis]: University of Kentucky, unknown p.

Bayan, M. R., and Ettensohn, F. R., 1993, Supergene alteration of substrates below DevonianMississippian oil and gas shales: origin and significance, in 1993 Eastern Oil Shale Symposium, Lexington, Kentucky, p. 376-380.

Beard, J. G., 1980, Devonian black shale study of western Kentucky: Final status report: Lexington, Kentucky Geological Survey, Open File Report OF-80-02, 113 p.

Beato, B. D., Yost, R. A., Van Berkel, G. J., Filby, R. H., and Quirke, J. M. E., 1991, The Henryville Bed of the New Albany shale; III, Tandem mass spectrometric analyses of geoporphyrins from the bitumen and kerogen: Organic Geochemistry, v. 17, no. 1, p. 93-105.

Beran, M. A., 1995, Carbon sequestration in the biosphere: processes and prospects: Berlin, New York, Springer, p. 305.

Bethke, C. M., Reed, J. D., and Oltz, D. F., 1991, Long-range petroleum migration in the Illinois Basin: American Association of Petroleum Geologists Bulletin, v. 75, no. 5, p. 925-945.

Boberg, W. S., Lumm, D. K., Frankie, W. T., and Hamilton-Smith, T., 1994, Cross sections showing members of the New Albany shale (Devonian and Mississippian) in the Illinois Basin, in Hasenmueller, N. R., and Comer, J. B., eds., Gas potential of the New Albany shale (Devonian and Mississippian) in the Illinois Basin: Illinois Basin Consortium, Gas Research Institute 920391/Illinois Basin Studies 2, plate 5.

Booras, G. S., and Smelser, S. C., 1991, An Engineering and Economic Evaluation of $\mathrm{CO}_{2}$ Removal from Fossil-Fuel-Fired Power Plants: Energy, v. 16, no. 11/12, p. 1295-1305.

Boswell, R., 1996, Play UDs: Upper Devonian black shales, in Roen, J. B., and Walker, B. J., eds., The atlas of major Appalachian gas plays: Morgantown, WV, West Virginia Geological and Economic Survey, Publication V-25, p. 93-99.

Bownocker, J. A., and Dean, E. S., 1929, Analyses of the coals of Ohio, Ohio Division of Geological Survey, Bulletin 34, 360 p.

Broadhead, R. F., 1990, Bravo Dome carbon dioxide gas field, in Beaumont, E. A., and Foster, N. H., eds., Structural Traps I, AAPG Treatise of Petroleum Geology - Atlas of Oil and Gas Fields: Tulsa, Oklahoma, American Association of Petroleum Geologists, p. 213-232.

Browne, R., Conkin, J., Conkin, B., and MacCary, L. M., 1958, Geological Society of Kentucky field trip, sedimentation and stratigraphy of Silurian and Devonian rocks in the Louisville area, Kentucky: Lexington, KY, Kentucky Geological Survey, 46 p.

Burruss, R. C., 1999, Options for sequestration of carbon dioxide; an energy resource perspective [abs]: Abstracts with Programs Geological Society of America, v. 31, no. 7, p. 29-30. 
Byrer, C. W., and Guthrie, H. D., 1999, Carbon dioxide sequestration potential in coal deposits, in Program and Abstracts of the 1999 Annual Convention American Association of Petroleum Geologists, San Antonio, TX, April 11-14, 1999, p. A18.

Byrnes, A. P., and Cluff, R. M., 1992, Lopatin analysis of maturation and petroleum generation in the Illinois Basin: American Association of Petroleum Geologists Bulletin, v. 76, no. 8, p. 1272.

Caramanica, F. P., 1995, Relationships between gas production and natural fractures in the Antrim shaleApplications to the New Albany shale, in Gas potential of the New Albany shale workshop, Evansville, Indiana, p. M1, illustrated.

Casey, G. D., 1992, Preliminary hydrogeologic framework of the Silurian and Devonian carbonate aquifer system in the Midwestern basins and arches region of Indiana, Ohio, Michigan, and Illinois: Abstracts with Programs, Geological Society of America, v. 24, no. 7, p. 281-282.

Chohji, T., Tabata, M., and Hirai, E., 1997, $\mathrm{CO}_{2}$ Recovery from Flue Gas by an Ecotechnological (Environmentally Friendly) System: Energy, v. 22, no. 2/3, p. 151-159.

Clarkson, C. R., and Bustin, R. M., 1996, Variation in micropore capacity and size distribution with composition in bituminous coal of the Western Canadian Sedimentary Basin: Implications for coalbed methane potential: Fuel, v. 75, no. 13, p. 1483-1498.

Cluff, R. M., 1993, Source rocks and hydrocarbon generation in the New Albany shale (DevonianMississippian) of the Illinois Basin; a review, in Roen, J. B., and Kepferle, R. C., eds., Petroleum geology of the Devonian and Mississippian black shale of eastern North America: U. S. Geological Survey Bulletin, p. I1-I15.

Cluff, R. M., Cluff, S. G., and Murphy, C. M., 1996, Devonian shale gas resource assessment, Illinois Basin: Annual Meeting Abstracts, American Association of Petroleum Geologists and Society of Economic Paleontologists and Mineralogists, v. 5, p. 28.

Cluff, R. M., Reinbold, M. L., and Lineback, J. A., 1981, The New Albany Shale Group of Illinois: Champaign, Illinois, Illinois State Geological Survey, Circular 518, 83 p.

Comer, J. B., 1995, Thermal maturity of the New Albany shale (Devonian and Mississippian) in the Illinois Basin, in Gas potential of the New Albany shale workshop, Evansville, Indiana, p. E1-E2, illustrated.

Comer, J. B., Hamilton-Smith, T., and Frankie, W. T., 1994, Source rock potential, in Hasenmueller, N. R., and Comer, J. B., eds., Gas potential of the New Albany shale (Devonian and Mississippian) in the Illinois Basin: Illinois Basin Consortium, Gas Research Institute 92-0391/Illinois Basin Studies 2, p. 47-54.

Comer, J. B., Hasenmueller, N. R., Frankie, W. T., and Hamilton-Smith, T., 1993, Gas potential of New Albany shale (Devonian-Mississippian) in the Illinois Basin [abs], Eastern Oil Shale Symposium Abstracts, November 16-19, 1993: Lexington, Kentucky, Institute for Mining and Minerals Research, p. 71.

Comer, J. B., Hasenmueller, N. R., Frankie, W. T., and Hamilton-Smith, T., 1994, Gas potential of New Albany shale (Devonian-Mississippian) in the Illinois Basin, in Schultz, A. P., and Rader, E. K., eds., Studies in eastern energy and the environment; AAPG Eastern Section special volume: Virginia Division of Mineral Resources, Publication 132, p. 178-179.

Comer, J. B., Hasenmueller, N. R., Frankie, W. T., and Hamilton-Smith, T., 1994, Gas potential of New Albany shale (Devonian-Mississippian) in the Illinois Basin [abs]: American Association of Petroleum Geologists Bulletin, Eastern Section Meeting Abstracts, v. 77, no. 8, p. 1467. 
Comer, J. B., Smidchens, Z., Irwin, P. N., Sowder, K. H., Frankie, W. T., Lumm, D. K., and HamiltonSmith, T., 1994, Map showing mean random vitrinite reflectance (Ro) for New Albany shale (Devonian and Mississippian) gas fields in the Illinois Basin, in Hasenmueller, N. R., and Comer, J. B., eds., Gas potential of the New Albany shale (Devonian and Mississippian) in the Illinois Basin: Illinois Basin Consortium, Gas Research Institute 92-0391/Illinois Basin Studies 2, plate 7, scale $1: 1,000,000$.

Concha, M. A., Quirke, J. M. E., Beato, B. D., Yost, R. A., Mercer, G. E., and Filby, R. H., 1991, The Henryville Bed of the New Albany shale; IV, Tandem mass spectrometric analyses of geoporphyrins from the bitumen of the demineralised shale: Chemical Geology, v. 91, no. 2, p. 153-168.

Currie, M. T., 1981, Subsurface stratigraphy and depositional environments of the "Corniferous" (Silurian-Devonian) of Eastern Kentucky [Thesis thesis]: University of Kentucky, unknown p.

Department of Energy, 1999, Energy Department to Fund Further Studies of Six Concepts for Capturing, Disposing of Greenhouse Gases, DOE Techline Press Release.

Desborough, G. A., 1992, Mineralogical and geochemical analysis of the metal- and organic-rich Grassy Creek shale of the New Albany Group (Upper Devonian and Lower Mississippian) in Hardin County, southern Illinois, in Day, W. C., and Lane, D. E., eds., Strategic and critical minerals in the Midcontinent region, United States: U. S. Geological Survey Bulletin, p. C1-C9.

Diagne, D., Goto, M., and Hirose, T., 1995, Parametric Studies on $\mathrm{CO}_{2}$ Separation and Recovery by a Dual Reflux PSA Process Consisting of Both Rectifying and Stripping Sections: Industrial \& Engineering Chemistry Research, v. 34, no. 9, p. 3083-3089.

Dias, R. R., Freeman, K. H., Lewan, M. D., and Franks, S. G., 1997, Kerogen maturation and the delta 13C of organic acids in oil-associated waters: American Association of Petroleum Geologists and Society of Economic Paleontologists and Mineralogists, Annual Meeting Abstracts, v. 6, p. 2728.

Dillman, S. B., 1980, Subsurface geology of the Upper Devonian-Lower Mississippian black shale sequence in Eastern Kentucky [M.S. thesis]: University of Kentucky, unknown p.

Dillman, S. B., 1980, Subsurface geology of the Upper Devonian-Lower Mississippian black shale sequence in Eastern Kentucky [M.S. thesis]: University of Kentucky, unknown p.

Dillman, S. B., and Ettensohn, F. R., 1980a, Isopach map of the Cleveland shale member (Unit 1) of the Ohio shale in eastern Kentucky: United States Department of Energy, Morgantown Energy Technology Center, Eastern Gas Shales Project, METC/EGSP Series 522, scale 1:370,000.

Dillman, S. B., and Ettensohn, F. R., 1980b, Isopach map of the Devonian black-shale sequence (New Albany-Chattanooga-Ohio shale) in eastern Kentucky: United States Department of Energy, Morgantown Energy Technology Center, Eastern Gas Shales Project, METC/EGSP Series 515, scale $1: 370,000$.

Dillman, S. B., and Ettensohn, F. R., 1980c, Isopach map of the Lower Huron shale member (Unit 5) of the Ohio shale in eastern Kentucky: United States Department of Energy, Morgantown Energy Technology Center, Eastern Gas Shales Project, METC/EGSP Series 518, scale 1:370,000.

Dillman, S. B., and Ettensohn, F. R., 1980d, Isopach map of the Middle Huron shale member (Unit 4) of the Ohio shale in eastern Kentucky: United States Department of Energy, Morgantown Energy Technology Center, Eastern Gas Shales Project, METC/EGSP Series 519, scale 1:370,000.

Dillman, S. B., and Ettensohn, F. R., 1980e, Isopach map of the Rhinestreet shale (Unit 7) in eastern Kentucky: United States Department of Energy, Morgantown Energy Technology Center, Eastern Gas Shales Project, METC/EGSP Series 516, scale 1:370,000. 
Dillman, S. B., and Ettensohn, F. R., 1980f, Isopach map of the Three Lick bed (Unit 2) of the Ohio shale in eastern Kentucky: United States Department of Energy, Morgantown Energy Technology Center, Eastern Gas Shales Project, METC/EGSP Series 521, scale 1:370,000.

Dillman, S. B., and Ettensohn, F. R., 1980g, Isopach map of the Upper Huron Shale member (Unit 3) of the Ohio shale in eastern Kentucky: United States Department of Energy, Morgantown Energy Technology Center, Eastern Gas Shales Project, METC/EGSP Series 520, scale 1:370,000.

Dillman, S. B., and Ettensohn, F. R., 1980h, Isopach map of the Upper Olentangy shale (Unit 6) in eastern Kentucky: United States Department of Energy, Morgantown Energy Technology Center, Eastern Gas Shales Project, METC/EGSP Series 517, scale 1:370,000.

Dillman, S. B., and Ettensohn, F. R., 1980i, Structure contour map on the base of the Cleveland shale member (Unit 1) of the Ohio shale in eastern Kentucky: United States Department of Energy, Morgantown Energy Technology Center, Eastern Gas Shales Project, METC/EGSP Series 514, scale 1:370,000.

Dillman, S. B., and Ettensohn, F. R., 1980j, Structure contour map on the base of the Java formation/Olentangy shale (Unit 6) in eastern Kentucky: United States Department of Energy, Morgantown Energy Technology Center, Eastern Gas Shales Project, METC/EGSP Series 509, scale $1: 370,000$.

Dillman, S. B., and Ettensohn, F. R., 1980k, Structure contour map on the base of the Lower Huron shale member (Unit 5) of the Ohio shale in eastern Kentucky: United States Department of Energy, Morgantown Energy Technology Center, Eastern Gas Shales Project, METC/EGSP Series 510, scale $1: 370,000$.

Dillman, S. B., and Ettensohn, F. R., 19801, Structure contour map on the base of the Middle Huron shale member (Unit 4) of the Ohio shale in eastern Kentucky: United States Department of Energy, Morgantown Energy Technology Center, Eastern Gas Shales Project, METC/EGSP Series 511, scale $1: 370,000$.

Dillman, S. B., and Ettensohn, F. R., 1980m, Structure contour map on the base of the Ohio shale in eastern Kentucky: United States Department of Energy, Morgantown Energy Technology Center, Eastern Gas Shales Project, METC/EGSP Series 507, scale 1:370,000.

Dillman, S. B., and Ettensohn, F. R., 1980n, Structure contour map on the base of the Three Lick bed (Unit 2) of the Ohio shale in eastern Kentucky: United States Department of Energy, Morgantown Energy Technology Center, Eastern Gas Shales Project, METC/EGSP Series 513, scale 1:370,000.

Dillman, S. B., and Ettensohn, F. R., 1980o, Structure contour map on the base of the Upper Huron Shale member (Unit 3) of the Ohio shale in eastern Kentucky: United States Department of Energy, Morgantown Energy Technology Center, Eastern Gas Shales Project, METC/EGSP Series 512, scale 1:370,000.

Dillman, S. B., and Ettensohn, F. R., 1980p, Structure contour map on the base of the West Falls Formation (Rhinestreet shale, Unit 7) in eastern Kentucky: United States Department of Energy, Morgantown Energy Technology Center, Eastern Gas Shales Project, METC/EGSP Series 508, scale 1:370,000.

Doctor, R. D., Molburg, J., Brockmeier, N. F., and Chess, K., 1998, Engineering Assessment of $\mathrm{CO}_{2}$ Recovery, Transport, and Utilization: Argonne National Laboratory.

Drahovzal, J. A., Harris, D. C., Wickstrom, L. H., Walker, D., Baranoski, M. T., Keith, B. D., and Furer, L. C., 1992, The East Continent Rift Basin, a new discovery, Kentucky Geological Survey, Series 11, Special Publication 18, 25 p. 
Dubois, M. K., Byrnes, A. P., Pancake, R. E., Willhite, G. P., and Schoeling, L. G., 2000, Economics show $\mathrm{CO}_{2}$ EOR potential in central Kansas: Oil and Gas Journal, June 5, 2000, v. 98, no. 23, p. $37-41$.

Dyman, T. S., Schmoker, J. W., and Root, D. H., 1998, Emerging U.S. gas resources 2-USGS assesses deep undiscovered gas resource: Oil \& Gas Journal, April 20, 1998, p. 99-104.

Energy Information Administration, 1996, Annual Energy Outlook 1997 with projections to 2015: Washington, DC, Government Printing Office, DOE/EIA-0383(97), 212 p.

Energy Information Administration, 1996, Annual Energy Outlook 1997 with projections to 2015: Washington, DC, U.S. Department of Energy, Government Printing Office, DOE/EIA-0383(97), p. 212.

Energy Information Administration, 1997, Annual Energy Outlook 1998 with projections to 2020: Washington, DC, U.S. Department of Energy, Government Printing Office, DOE/EIA-0383(98), p. 227.

Energy Information Administration, 1997, Annual Energy Outlook 1998 with projections to 2020: Washington, DC, Government Printing Office, DOE/EIA-0383(98), 212 p.

Energy Information Administration, 1998, Annual Energy Outlook 1999 with projections to 2020: Washington, DC, U.S. Department of Energy, Government Printing Office, DOE/EIA-0383(99), p. 233.

Energy Information Administration, 1998, Annual Energy Outlook 1999 with projections to 2020: Washington, DC, Government Printing Office, DOE/EIA-0383(99), 233 p.

Energy Information Administration, 1999, Annual Energy Outlook 2000 with projections to 2020: Washington, DC, U.S. Department of Energy, Government Printing Office, DOE/EIA0383(2000), $250 \mathrm{p}$.

Energy Information Administration, 1999, Annual Energy Outlook 2000 with projections to 2020: Washington, DC, U.S. Department of Energy, Government Printing Office, DOE/EIA0383(2000), p. 250.

Energy Information Administration, 2000, Emissions of greenhouse gases in the United States 1999, Energy Information Administration, U. S. Department of Energy, EIA/DOE-0573(99).

Erga, O., Juliussen, O., and Lidal, H., 1995, Carbon Dioxide Recovery by Means of Aqueous Amines: Energy Conversion Management, v. 36, no. 6-9, p. 387-392.

Ettensohn, F. R., Barnett, S. G., and Norby, R. D., 1994, Late-Middle to Late Devonian (GivetianFamennian) tectonic and stratigraphic history of central Kentucky: Geological Society of America, Abstracts with Programs, v. 26, no. 5, p. 14-15.

Ettensohn, F. R., 1998, Compressional tectonic controls on epicontinental black-shale deposition; Devonian-Mississippian examples from North America, in Scheiber, J., Zimmerle, W., and Sethi, P. S., eds., Shales and mudstones; I, Basin studies, sedimentology, and paleontology: Stuttgart, E Schweizerbart'sche Verlagsbuchhandlung Naegele u. Obermiller, p. 109-128.

Fallin, J. A., ed., 1984, Carbon dioxide and its applications to enhanced oil recovery, Petroleum Frontiers, $63 \mathrm{p}$.

Felty, K. K., 1989, Stratigraphy of the Silurian and Devonian in Western Marion and Southern Nelson Counties [Thesis thesis]: University of Kentucky, unknown p. 
Foerste, A. E., 1910, Oil, gas, and asphalt rock, in Meade and Breckinridge Counties, in Norwood, C. J., ed., Report on the Progress of the Survey for the years 1908 and 1909: Lexington, Kentucky, Kentucky Geological Survey, p. 69-85.

Foster, R. W., and Jensen, J. G., 1972, Carbon dioxide in northeastern New Mexico, New Mexico Geological Society Guidebook to 23rd field conference, p. 192-200.

Frankie, W. T., Lumm, D. K., Boberg, W. S., Comer, J. B., and Hamilton-Smith, T., 1994, Data and Methods, in Hasenmueller, N. R., and Comer, J. B., eds., Gas potential of the New Albany shale (Devonian and Mississippian) in the Illinois Basin: Illinois Basin Consortium, Gas Research Institute 92-0391/Illinois Basin Studies 2, p. 5-8.

Frankie, W. T., Lumm, D. K., Boberg, W. S., Hamilton-Smith, T., and Noger, M. C., 1994, Map showing major structural features in the Illinois Basin, in Hasenmueller, N. R., and Comer, J. B., eds., Gas potential of the New Albany shale (Devonian and Mississippian) in the Illinois Basin: Illinois Basin Consortium, Gas Research Institute 92-0391/Illinois Basin Studies 2, plate 1, scale $1: 1,000,000$.

Frankie, W. T., Lumm, D. K., Boberg, W. S., Hasenmueller, N. R., Smidchens, Z., and Hamilton-Smith, T., 1994, Map showing elevation of the top of the New Albany shale (Devonian and Mississippian) in the Illinois Basin, in Hasenmueller, N. R., and Comer, J. B., eds., Gas potential of the New Albany shale (Devonian and Mississippian) in the Illinois Basin: Illinois Basin Consortium, Gas Research Institute 92-0391/Illinois Basin Studies 2, plate 3, scale 1:1,000,000.

Frankie, W. T., Lumm, D. K., Boberg, W. S., Hasenmueller, N. R., Smidchens, Z., and Hamilton-Smith, T., 1994, Map showing total thickness of the top of the New Albany shale (Devonian and Mississippian) in the Illinois Basin, in Hasenmueller, N. R., and Comer, J. B., eds., Gas potential of the New Albany shale (Devonian and Mississippian) in the Illinois Basin: Illinois Basin Consortium, Gas Research Institute 92-0391/Illinois Basin Studies 2, plate 4, scale 1:1,000,000.

Frankie, W. T., Moody, J. R., and Kemper, J. R., 1986, Geologic and hydrocarbon report of Letcher County: Part 1 of 5, Hydrocarbon production from the Devonian Shale in Letcher, Knott, Floyd, Martin, and Pike Counties, eastern Kentucky: Lexington, Kentucky, Kentucky Geological Survey, Gas Research Institute contract report, contract 5084-213-0990, 59 p.

Frankie, W. T., Moody, J. R., Kemper, J. R., and Johnston, I. M., 1986, Geologic and hydrocarbon report of Floyd County: Part 3 of 5, Hydrocarbon production from the Devonian Shale in Letcher, Knott, Floyd, Martin, and Pike Counties, eastern Kentucky: Lexington, Kentucky, Kentucky Geological Survey, Gas Research Institute contract report, contract 5084-213-0990, 52 p.

Frankie, W. T., Moody, J. R., Kemper, J. R., and Johnston, I. M., 1986, Geologic and hydrocarbon report of Knott County: Part 2 of 5, Hydrocarbon production from the Devonian Shale in Letcher, Knott, Floyd, Martin, and Pike Counties, eastern Kentucky: Lexington, Kentucky, Kentucky Geological Survey, Gas Research Institute contract report, contract 5084-213-0990, 94 p.

Freeman, L. B., 1939, A sample study of the Devonian of Western Kentucky: Lexington, Department of Mines and Minerals, Geological Division, [Kentucky Geological Survey] Series 8, Bulletin 4, 27 p.

Freeman, L. B., 1951, Regional aspects of Silurian and Devonian stratigraphy in Kentucky: Lexington, Kentucky Geological Survey, Series 9, Bulletin 6 (reprinted 1959), 575 p.

Fronts, J. H., Jr., 1995, Economics of drilling and completing New Albany shale wells, in Gas potential of the New Albany shale workshop, Evansville, Indiana, p. L1-L2, illustrated.

Frost, J. K., 1996, Geochemistry of black shales of the New Albany Group (Devonian-Mississippian) in the Illinois Basin: relationships between lithofacies, and the carbon, sulfur and iron contents, 
Illinois State Geological Survey Circular 557: Urbana, Illinois, Illinois State Geological Survey, $24 \mathrm{p}$.

Frost, J. K., and Shaffer, N. R., 1994, Mineralogy and geochemistry, in Hasenmueller, N. R., and Comer, J. B., eds., Gas potential of the New Albany shale (Devonian and Mississippian) in the Illinois Basin: Illinois Basin Consortium, Gas Research Institute 92-0391/Illinois Basin Studies 2, p. 4145.

Fullerton, D. S., 1961, The geology of the Silurian and Devonian in the subsurface of Larue County, Kentucky [Thesis thesis]: University of Kentucky, unknown p.

Fulmer, J. E., 1992, Geologic and production comparisons of the New Albany shale of the Illinois Basin with the Michigan Basin's Antrim shale and the Appalachian Basin's Ohio shale: American Association of Petroleum Geologists Bulletin, Eastern Section Meeting Abstracts, v. 76, no. 8, p. 1274.

Fulton, L. P., 1979, Structure and isopach map of the New Albany-Chattanooga-Ohio shale (Devonian and Mississippian) in Kentucky, eastern sheet: Kentucky Geological Survey, Series 10, scale $1: 250,000$ (with correction sheet).

Furer, L. C., 1996, Basement tectonics in the southeastern part of the Illinois Basin and its effect on Paleozoic sedimentation, in van der Pluijm, B. A., and Catacosinos, P. A., eds., Basement and basins of eastern North America: Geological Society of America, Special Paper 308, p. 109-126.

Gatens, J. M., III, 1995, Practical reservoir engineering in the New Albany shale, in Gas potential of the New Albany shale workshop, Evansville, Indiana, p. I1, illustrated.

Gautier, D. L., Dolton, G. L., Takahashi, K. I., and Varnes, K. L., 1996, 1995 national assessment of United States oil and gas resources--results, methodology, and supporting data: Washington, DC, United States Geological Survey, Digital Data Series DDS-30, release 2, CD-ROM.

Geller, K. L., 1985, Stratigraphic relationships between the Devonian-Mississippian black shale sequence in the Appalachian and Illinois Basins [Thesis thesis]: University of Kentucky, unknown p.

Gentzis, T., 2000, Subsurface sequestration of carbon dioxide; an overview from an Alberta (Canada) perspective: International Journal of Coal Geology, v. 43, no. 1-4, p. 287-305.

Gerling, C. R., 1983, McElmo dome Leadville carbon dioxide field, Colorado, in Fassett, J. E., ed., Oil and gas fields of the Four Corners area, Four Corners Geological Society, p. 735-739.

Gharrabi, M., and Velde, B., 1995, Clay mineral evolution in the Illinois Basin and its causes: Clay Minerals, v. 30, no. 4, p. 353-364.

Goff, F., Guthrie, G., Counce, D., Kluk, E., Bergfeld, D., and Snow, M., 1997, Preliminary investigations on the $\mathrm{CO}_{2}$ sequestering potential of ultramafic rocks, Los Alamos National Laboratory Report LA-13328-MS.

Goff, F., and Lackner, K. S., 1998, Carbon dioxide sequestering using ultramafic rocks: Environmental Geosciences, v. 5, no. 3, p. 89-101.

Gognat, T. A., Payne, G. A., Swenson, A., and Shurr, G. W., 1995, Exploration for and evaluation of the hydrocarbon potential of the New Albany shale, Illinois Basin, USA, in Gas potential of the New Albany shale workshop, Evansville, Indiana, p. N1.

Grover, J., and Dupuis-Nouille, E. M., 1992, Orientation of tectonic stresses in central Kentucky during U. Devonian/L. Mississippian times; evidence from quartz veins (after gypsum) in NE-trending, systematic joints in shales: Geological Society of America, Abstracts with Programs, v. 24, no. 7, p. 183. 
Grover, J., and Dupuis-Nouille, E. M., 1995, Tectonic stress directions in the central Mid-continent and the systematic orientation of lineaments and joints; a correspondence that has endured since Devonian time: Geological Society of America, Abstracts with Programs, v. 27, no. 6, p. 384.

Gunderson, L. C. S., Schumann, R. R., Otton, J. K., Owen, D. E., and Dubiel, R. F., 1991, Geologic radon potential of the United States: Geological Society of America, Abstracts with Programs, v. 23, no. 1, p. 39.

Gunter, W. D., Bachu, S., Law, D. H.-S., Marwaha, V., Drysdale, D. L., MacDonald, D. E., and McCann, T. J., 1996, Technical and economic feasibility of $\mathrm{CO}_{2}$ disposal in aquifers within the Alberta sedimentary basin, Canada: Energy Conservation and Management, v. 37, no. 6-8, p. 1135-1142.

Gunter, W. D., Gentzis, T., Rottenfusser, B. A., and Richardson, R. J. H., 1997, Deep coalbed methane in Alberta, Canada: A fuel resource with the potential of zero greenhouse gas emissions: Energy Conservation and Managment, v. 38, p. 217-222.

Gunter, W. D., Wong, S., Cheel, D. B., and Sjostrom, G., 1998, Large $\mathrm{CO}_{2}$ sinks: Their role in the mitigation of greenhouse gases from an international, national (Canadian) and provincial (Alberta) perspective: Applied Energy, v. 61, p. 209-227.

Hall, V. S., 1980, An eastern gas shales bibliography selected annotations gas, oil, uranium, etc., citations in bituminous shales worldwide: Morgantown, WV, United States Department of Energy, Morgantown Energy Technology Center, DOE/METC/12594-12, 532 p.

Hamilton-Smith, T., 1992, Gas production from the New Albany shale: American Association of Petroleum Geologists Bulletin, Eastern Section Meeting Abstracts, v. 76, no. 8, p. 1276-1277.

Hamilton-Smith, T., 1993, Gas exploration in the Devonian shales of Kentucky, Kentucky Geological Survey, Series 11, Bulletin 4, 31 p.

Hamilton-Smith, T., 1994, Temperature and pressure controls on the fractured Devonian shale gas play of the Appalachian Basin, in Berg, T. M., and Baranoski, M. T., eds., Ohio Geological Society Second annual symposium, Major natural gas plays of the Appalachian Basin of Ohio and surrounding areas: Ohio Geological Society, Canton, Ohio, Annual Technical Symposium, p. unpaginated.

Hamilton-Smith, T., 1995, History of gas production from the New Albany shale, in Gas potential of the New Albany shale workshop, Evansville, Indiana, p. F1-F2.

Hamilton-Smith, T., 1996, Fractured shale reservoirs; towards a realistic model: American Association of Petroleum Geologists Bulletin, Eastern Section meeting abstracts, v. 80, no. 9, p. 1524.

Hamilton-Smith, T., 1998, Deep, water-free gas potential in upside to New Albany shale play: Oil and Gas Journal, v. 96, no. 7, p. 70-71.

Hamilton-Smith, T., Boberg, W. S., Smidchens, Z., Frankie, W. T., and Lumm, D. K., 1994, Map showing average initial potential (IP) for New Albany shale (Devonian and Mississippian) gas fields in the Illinois Basin, in Hasenmueller, N. R., and Comer, J. B., eds., Gas potential of the New Albany shale (Devonian and Mississippian) in the Illinois Basin: Illinois Basin Consortium, Gas Research Institute 92-0391/Illinois Basin Studies 2, plate 6, scale 1:1,000,000.

Hamilton-Smith, T., Hasenmueller, N. R., Boberg, W. S., Smidchens, Z., and Frankie, W. T., 1994, Gas Production, in Hasenmueller, N. R., and Comer, J. B., eds., Gas potential of the New Albany shale (Devonian and Mississippian) in the Illinois Basin: Illinois Basin Consortium, Gas Research Institute 92-0391/Illinois Basin Studies 2, p. 23-40. 
Hamilton-Smith, T., Walker, D., and Nuttall, B. C., 1991, Fractured gas reservoirs in the Devonian shale of the Illinois and Appalachian basins: American Association of Petroleum Geologists Bulletin, Eastern Section meeting abstracts, v. 75, no. 8, p. 1383.

Hancock, S. K., 1999, Project brings commercial-scale $\mathrm{CO}_{2}$ miscible flooding to Canada: Oil and Gas Journal, no. Oct. 18, 1999, p. 70-75.

Haney, D. C., 1979, Geology and Energy Resources of Kentucky: The Interstate Oil Compact Commission Committee Bulletin, v. XXI, no. 1, p. 59-62.

Hanisch, C., 1999, Exploring Options for $\mathrm{CO}_{2}$ Capture and Management: Environmental Science and Technology, v. 33, no. 3, p. 66.

Hasenmueller, N. R., 1993, New Albany shale (Devonian and Mississippian) of the Illinois Basin, in Roen, J. B., and Kepferle, R. C., eds., Petroleum geology of the Devonian and Mississippian black shale of eastern North America: U. S. Geological Survey Bulletin 1909, p. C1-C19.

Hasenmueller, N. R., Boberg, J., Lumm, D. K., Frankie, W. T., Hamilton-Smith, T., and Comer, J. B., 1994, Stratigraphy, in Hasenmueller, N. R., and Comer, J. B., eds., Gas potential of the New Albany shale (Devonian and Mississippian) in the Illinois Basin: Illinois Basin Consortium, Gas Research Institute 92-0391/Illinois Basin Studies 2, p. 13-21.

Hasenmueller, N. R., Boberg, W. S., Comer, J., Smidchens, Z., Frankie, W. T., Lumm, D. K., HamiltonSmith, T., and Walker, J. D., 1991, Study of gas production potential of New Albany shale (Group) in the Illinois Basin: American Association of Petroleum Geologists Bulletin, Eastern Section meeting abstracts, v. 75, no. 8, p. 1383.

Hasenmueller, N. R., Boberg, W. S., Comer, J., Smidchens, Z., Frankie, W. T., Lumm, D. K., HamiltonSmith, T., and Walker, J. D., 1991, Study of gas production potential of New Albany shale (Group) in the Illinois Basin, in Goldhaber, M. B., and Eidel, J. J., eds., U. S. Geological Survey, Open-file Report, 19 p.

Hasenmueller, N. R., Boberg, W. S., Comer, J. B., Smidchens, Z., Frankie, W. T., Lumm, D. K., Hamilton-Smith, T., and Walker, J. D., 1991, Study of gas production potential of New Albany shale (Group) in the Illinois Basin [abs], Eastern Oil Shale Symposium Abstracts, November 1619, 1993: Lexington, Kentucky, Institute for Mining and Minerals Research, p. 78.

Hasenmueller, N. R., and Comer, J. B., 1994, Gas potential of the New Albany shale (Devonian and Mississippian) in the Illinois Basin, Illinois Basin Consortium, Gas Research Institute $92-$ 0391/Illinois Basin Studies 2, p. 83.

Hasenmueller, N. R., and Comer, J. B., 1995, Gas potential of the New Albany shale workshop: Evansville, Indiana, March 1, 1995, Gas Research Institute and Illinois Basin Consortium, p. 274.

Hasenmueller, N. R., Comer, J. B., Irwin, P. N., Sowder, K., Zuppann, C. W., Carpenter, J., Morse, D. G., Nuttall, B. C., and Hill, D. G., 1999, A new GIS compilation of "Final Report GRI920391/Illinois Basin Studies 2: Gas potential of New Albany shale (Devonian and Mississippian) in the Illinois Basin": American Association of Petroleum Geologists Bulletin, v. 83, no. 8, p. 1369.

Hasenmueller, N. R., Comer, J. B., Morse, D. G., Nuttall, B. C., DeChurch, D., Hill, B. T., Hill, R. T., Irwin, P. N., Like, K. K., Sowder, K., Thompson, T. A., and Zoltin, A., 2000, GIS compilation of gas potential of the New Albany shale in the Illinois Basin, Illinois Basin Consortium, Gas Research Institute CD-ROM GRI-00/0068.

Hasenmueller, N. R., Shaffer, N. R., and Comer, J. B., 1995, Cores of the New Albany shale from wells in Indiana, in Gas potential of the New Albany shale workshop, Evansville, Indiana, p. O1-O42. 
Haugan, P. M., and Drange, H., 1992, Sequestration of $\mathrm{CO}_{2}$ in the deep ocean by shallow injection: Nature, v. 357, no. 6376, p. 318-320.

Helton, W. L., 1963, The Silurian-Devonian stratigraphy of Pulaski County, Kentucky, and some features of the pre Mid-Devonian uncomformity [Thesis thesis]: University of Kentucky, unknown p.

Hendriks, C., 1994, Carbon Dioxide Removal from Coal-Fired Power Plants, Energy \& Environment: Boston, Kluwer Academic Publishers, 233 p.

Herzog, H., 1998, The Economics of $\mathrm{CO}_{2}$ Capture, in Fourth International Conference on Greenhouse Gas Control Technologies, Interlaken, Switzerland.

Herzog, H., Drake, E., and Adams, E., 1997, $\mathrm{CO}_{2}$ Capture, Reuse, and Storage Technologies for Mitigating Global Climate Change: Energy Laboratory, MIT, DOE Order No. DE-AF2296PC01257.

Herzog, H., Eliasson, B., and Kaarstad, O., 2000, Capturing greenhouse gases: Scientific American, v. 282, no. 2, p. $72-79$.

Herzog, H., Schmidt, C., and Drake, E., 1998, $\mathrm{CO}_{2}$ Sequestration: Opportunities for GovernmentIndustry-Academia Partnerships, in Fourth International Conference on Greenhouse Gas Control Technologies, Interlaken, Switzerland.

Herzog, H., and Vukmirovic, N., 1999, $\mathrm{CO}_{2}$ Sequestration: Opportunities and Challenges, in 7th Clean Coal Technology Conference, Knoxville, TN.

Hill, D. G., 1995, An overview of productive gas shales, in Gas potential of the New Albany shale workshop, Evansville, Indiana, p. G1-G2, illustrated.

Hitchon, B., 1996, Aquifer disposal of carbon dioxide: hydrodynamic and mineral trapping, in Hitchon, B., ed., Proof of Concept: Sherwood Park, Alberta, p. 165.

Hitchon, B., Gunter, W. D., Gentiz, T., and Bailey, R. T., 1999, Sedimentary basins and greenhouse gases: a serendipitous association: Energy Conservation and Management, v. 40, no. 8, p. 825843.

Holbrook, C. E., 1964, Stratigraphic relationships of the Silurian and Devonian in Clark, Powell, Montgomery and Bath Counties [Thesis thesis]: University of Kentucky, unknown p.

Holloway, S., 1996, An overview of the Joule II project "The underground disposal of carbon dioxide": Energy Conservation and Management, v. 37, no. 6-8, p. 1149-1154.

Holloway, S., Rochelle, C. A., and Pearce, J. M., 1999, Geological sequestration of carbon dioxide; implications for the coal industry: Institution of Mining and Metallurgy, Transactions, Section B: Applied Earth Science, v. 108, p. 19-22.

Hopkins, C., 1995, Completion technology, in Gas potential of the New Albany shale workshop, Evansville, Indiana, p. K1-K2, illustrated.

Hornbrook, M. W., Dehghani, K., Qadeer, S., Ostermann, R. D., and Ogbe, D. O., 1991, Effects of $\mathrm{CO}_{2}$ Addition to Steam Recovery of West Sak Crude Oil: SPE Reservoir Engineering, v. 63, p. 278286.

Hover, V. C., Peacor, D. R., and Walter, L. M., 1996, Relationship between organic matter and authigenic illite/ smectite in Devonian black shales, Michigan and Illinois basins, USA, in Crossey, L. J., Loucks, R., and Totten, M. W., eds., Siliciclastic diagenesis and fluid flow; concepts and applications: SEPM (Society for Sedimentary Geology), Special Pub. 55, p. 73-83.

Hover, V. C., Peacor, R. R., and Walter, L. M., 1993, Shale microstructure and chemistry in cratonic basins; does shale authigenesis follow the Gulf Coast paradigm?: American Association of 
Petroleum Geologists and Society of Economic Paleontologists and Mineralogists, Annual Meeting Abstracts, p. 121.

Hover, V. C., Peacor, R. R., and Walter, L. M., 1996, STEM/AEM evidence for preservation of burial diagenetic fabrics in Devonian shales; implications for fluid/rock interaction in cratonic basins (U.S.A.): Society of Economic Paleontologists and Mineralogists, Journal of Sedimentary Research, Section A: Sedimentary Petrology and Processes, v. 66, no. 3, p. 519-530.

Hovorka, S. D., and Dutton, A. R., 1999, Exploring for optimal geological environments for carbon dioxide disposal in saline aquifers in the United States, in Program and Abstracts of the 1999 Annual Convention American Association of Petroleum Geologists, San Antonio, TX, April 1114, 1999, p. A63.

Hughes, J. D., Dawson, F. M., Duggan, J., Hallas, D. F., Khitrova, G., Marchioni, D. L., Richardson, R., and Wynne, D., 1999, Regional analysis of the Ardley coal zone, Alberta, for coalbed methane production and $\mathrm{CO}_{2}$ sequestration, Geological Survey of Canada, Open-File Report, $116 \mathrm{p}$.

Hughes, R. E., Olive, W. W., Reuff, A. W., Baxter, J. W., Anderson, W. H., McFarland, M., and Stiff, B. J., 1992, Assessment of the clay and shale resources of the Paducah Quadrangle, in Goldhaber, M. B., and Eidel, J. J., eds., Mineral resources of the Illinois Basin in the context of basin evolution: U. S. Geological Survey, Open-file report, p. 28-29.

Hunter, C. D., and Young, D. M., 1953, Relationship of natural gas occurrence and production in eastern Kentucky (Big Sandy Gas Field) to joints and fractures in Devonian Bituminous shale: Lexington, Kentucky, Kentucky Geological Survey, Series 9, Reprint 7, 18 p.

Hunter, C. D., and Young, D. M., 1953, Relationship of natural gas occurrence and production in eastern Kentucky (Big Sandy Gas Field) to joints and fractures in Devonian bituminous shale: Bulletin of the American Association of Petroleum Geologists, v. 37, no. 2, p. 282-299.

IEA Greenhouse Gas R\&D Programme, SACS Project.

IEA Greenhouse Gas R\&D Programme, Saline Aquifer $\mathrm{CO}_{2}$ Storage (SACS).

Iijima, M., 1996, A Feasible New Flue Gas $\mathrm{CO}_{2}$ Recovery Technology for Enhanced Oil Recovery: Society of Petroleum Engineers, SPE 39686.

Ipsen, K. H., and Jacobsen, F. L., 1996, The Linde Structure, Denmark an example of a $\mathrm{CO}_{2}$ depository with a secondary chalk cap rock: Energy Conservation and Management, v. 37, no. 6-8, p. 11611166.

Ivy, S. M., and Fox, C. E., 1997, Improvements enhance $\mathrm{CO}_{2}$ flooding technology, planning maximize oil recovery using $\mathrm{CO}_{2}$ floods, Shell $\mathrm{CO}_{2}$.

Jenkins, J. L., 1981, Petrology and related studies of the Upper Devonian black shales in Eastern Kentucky [Thesis thesis]: West Virginia University, 115 p.

Jillson, W. R., 1932, The next oil pool; a general consideration of some of the undeveloped areas of outstanding merit in Kentucky: Lexington, Kentucky, Transylvania press, xiv , 1 ., 116 p.

Johnson, R. E., 1983, Bravo dome carbon dioxide area, northeast New Mexico, in Fassett, J. E., ed., Oil and gas fields of the Four Corners area, Four Corners Geological Society, p. 745-748.

Jordan, D. W., 1979, Trace fossils and stratigraphy of the Devonian Black Shale in east-central Kentucky [Thesis thesis]: University of Cincinnati, unknown p.

Jordan, D. W., 1985, Trace fossils and depositional environemnts of upper Devonian Black Shales, eastcentral Kentucky, U S A: The Society of Economic Paleontologists and Mineralogists., v. 35, p. 279-298. 
K\&A Energy Consultants, I., 1988, Significance of Geology to Gas Production from Devonian Shales of the Central Appalachian Basin: An Underdeveloped Asset: Chicago, Illinois, Gas Research Institute, Topical Report October 1, 1987--July 30, 1988, GRI Contract No. 5087-213-1617, 121 p.

Kaiser, J., 1998, Possibly Vast Greenhouse Gas Sponge Ignites Controversy: Science, v. 282, p. 386-387.

Kalafant, J. R., and Boyer, C. M., 1988, A geologic assessment of natural gas from coal seams in the central Appalachian Basin, topical report (January 1988-November 1988): Fairfax, VA, ICFLewan, prepared for the Gas Research Institute, contract number 5084-214-1066, GRI No. 88/0302, 66 p.

Keith, D. W., and Parson, E. A., 2000, A breakthrough in climate change policy?: Scientific American, v. 282, no. 2, p. 78-79.

Kelebeev, A. S., Akinfiev, N. N., and Shvets, V. M., 1996, Carbon dioxide utilization in aquifer: method for mitigation greenhouse effect: Energy Conservation and Management, v. 37, no. 6-8, p. 11431148 .

Kepferle, R. C., 1986, Devonian and Mississippian black shales of Kentucky: Geological Society of America Centennial Field Guide - Southeastern Section., v. 6, no. Southeastern Section of the Geological Society of America, p. 31-36.

Kikkinides, E. S., Yang, R. T., and Cho, S. H., 1993, Concentration and Recovery of $\mathrm{CO}_{2}$ from Flue Gas by Pressure Swing Adsorption: Industrial \& Engineering Chemistry Research, v. 32, no. 11, p. 2714-2720.

Kikkinides, E. S., Yang, R. T., and Cho, S. H., 1994, Response to Comments on "Concentration and Recovery of $\mathrm{CO}_{2}$ from Flue Gas by Pressure Swing Adsorption": Industrial \& Engineering Chemistry Research, v. 33, no. 11, p. 2881.

Kimura, N., Omata, K., Kiga, T., Takano, s., and Shikisima, S., 1995, The Characteristics of pulverized coal combustion in $\mathrm{O}_{2} / \mathrm{CO}_{2}$ mixtures for $\mathrm{CO}_{2}$ recovery: Energy Conversion and Management, v. 36, no. 6-9, p. 805-808.

Knauss, K. G., Copenhaver, S. A., Braun, R. L., and Burnham, A. K., 1997, Hydrous pyrolysis of New Albany and Phosphoria shales; production kinetics of carboxylic acids and light hydrocarbons and interactions between the inorganic and organic chemical systems: Organic Geochemistry, v. 27, no. 7-8, p. 477-496.

Kuuskraa, V. A., Schmoker, J. W., and Dyman, T. S., 1998, Diverse gas plays lurk in gas resource pyramid: Oil and Gas Journal, v. 96, no. 23, June 8, 1998, p. 123-130.

Kuuskraa, V. A., and Wicks, D. E., 1983, Technically recoverable Devonian shale gas in Ohio, U.S. Department of Energy, Morgantown Energy Technology Center, DOE/MC/19239-1525, 101 p.

Lancaster, D., and Gatens, J. M. III, 1989, Research targets Devonian shales: Northeast Oil World (NOW), p. 12-15.

Lang, W. B., 1959, The origin of some natural carbon dioxide gases: Journal of Geophysical Research, v. 64, p. 127-131.

Latil, M., 1980, Enhanced oil recovery: Paris, France, French Institute of Petroleum Publications, translation distributed by Gulf Publishing, Houston, 236 p.

Law, D. H.-S., and Bachu, S., 1996, Hydrogeological and numerical analysis of $\mathrm{CO}_{2}$ disposal in deep aquifers in the Alberta sedimentary basin: Energy Conservation and Management, v. 37, no. 6-8, p. 1167-1174. 
Lenhart, S. W., 1985, Structural and paleogeographic control of Devonian carbonate litho-stratigraphy of the adjacent to the Cincinnati Arch in south-central Kentucky [Thesis thesis]: University of Kentucky, unknown p.

Leventhal, J. S., and Shaw, V. E., 1980, Organic matter in Appalachian Devonian Black Shale: I. comparison of techiques to measure organic carbon, II. short range organic carbon content variations: Journal of Sedimentary Petrology, v. 50, no. 1, p. 0077-0081.

Lewan, M. D., Comer, J. B., Hamilton-Smith, T., Hasenmueller, N. R., Guthrie, J. M., Hatch, J. R., Gautier, D. L., and Frankie, W. T., 1995, Feasibility study of material-balance assessment of petroleum from the New Albany shale in the Illinois Basin, U.S. Geological Survey Bulletin 2137, $31 \mathrm{p}$.

Lewan, M. D., Henry, M. E., Higley, D. K., and Pitman, J. K., 1998, Material-balance approach to petroleum systems: New Albany shale/Chesterian of the Illinois Basin: American Association of Petroleum Geologists, Annual Convention Extended Abstracts, p. A401.

Lewis, J. O., 1949, A study of the geology of Preston (Boyle) ore in Bath County, Kentucky [Thesis thesis]: University of Kentucky, unknown p.

Los Alamos National Labs, 1998, Zero Emission Coal.

Lumm, D. K., 1995, Relationships between structural features, fracture orientations, and current stress in the Illinois Basin, in Gas potential of the New Albany shale workshop, Evansville, Indiana, p. D1-D3, illustrated.

Lumm, D. K., Frankie, W. T., Hasenmueller, N. R., and Hamilton-Smith, T., 1994, Illinois Basin geologic setting, in Hasenmueller, N. R., and Comer, J. B., eds., Gas potential of the New Albany shale (Devonian and Mississippian) in the Illinois Basin: Illinois Basin Consortium, Gas Research Institute 92-0391/Illinois Basin Studies 2, p. 9-12.

Lyle, D., 1999, $\mathrm{CO}_{2}$ for Kansas: Oil and Gas World, v. 91, no. 5, p. 25-26.

Malin, C. B., 2000, Petroleum industry faces challenge of change in confronting global warming: Oil and Gas Journal, August 28, 2000, v. 98, no. 35, p. 58-63.

Markowitz, G., 1979, A geochemical study of the Upper Devonian-Lower Mississippian black shales in Eastern Kentucky [Thesis thesis]: University of Kentucky, unknown p.

Martini, A. M., Walter, L. M., Ku, T. C. W., and Budai, J. M., 1997, Genetic and temporal relations between black shale formation waters and biogenic methane in Mid-Continent sedimentary basins: Geological Society of America, Abstracts with Programs, v. 29, no. 6, p. 156.

Maslowski, A., 1986, Logs help decipher Devonian shales: Northeast Oil World (NOW), p. 18-20.

Maslowski, A., 1986, Multi-well frac performed in Kentucky: Northeast Oil World (NOW), p. 29-30.

McPherson, B. J. O. L., and Cole, B. S., 2000, Multiphase $\mathrm{CO}_{2}$ flow, transport and sequestration in the Powder River basin, Wyoming, USA: Journal of Geochemical Exploration, p. 65-70.

Mercer, G. E., 1992, The distribution and association of trace elements in the bitumen, kerogen, and pyrolysates from New Albany oil shale [PhD Dissertation thesis]: Washington State University, $160 \mathrm{p}$.

Miller, B. J., 1990, Design and results of a shallow, light oilfield-wide application of $\mathrm{CO}_{2} \mathrm{Huff}^{\prime}$ 'Puff process: SPE/DOE 20268, p. 925-932.

Miller, B. J., and Hamilton-smith, T., 1998, Field Case: Cyclic gas recovery for light oil using carbon dioxide/nitrogen/natural gas: SPE 49169, p. 501-507. 
Miller, M. L., 1978, A petrographic study of the Upper Devonian-Lower Mississippi black shales in Eastern Kentucky [Thesis thesis]: University of Kentucky, unknown p.

Mines, U. S. B. o., 1965, Joint Committee on Petroleum-Impregnated Rocks, 29; 73-149 p.

Minihan, E. D., and Buzzart, R. D., 1995, Modern Devonian shale gas search starting in southwestern Indiana: Oil and Gas Journal, v. 93, no. 9, p. 58-62.

Minihan, E. D., and Buzzart, R. D., 1996, Gas sales starting from Indiana's fractured New Albany shale: Oil and Gas Journal, v. 94, no. 36, p. 96-97.

Moody, J. R., Kemper, J. R., Johnston, I. M., and Elkin, R. R., 1987, Geologic and hydrocarbon report of Pike County: Part 5 of 5, Hydrocarbon production from the Devonian Shale in Letcher, Knott, Floyd, Martin, and Pike Counties, eastern Kentucky: Lexington, Kentucky, Kentucky Geological Survey, Gas Research Institute contract report, contract 5084-213-0990, 51 p.

Moody, J. R., Kemper, J. R., Johnston, I. M., and Elkin, R. R., 1987, The geology and the drilling and production history of the Upper Devonian Shale of Whitley, Knox, Bell, and Harlan Counties, southeastern Kentucky: Lexington, Kentucky, Kentucky Geological Survey, Gas Research Institute contract report, contract 5084-213-0990, 30 p.

Moody, J. R., Kemper, J. R., Johnston, I. M., Elkin, R. R., and Smath, R. A., 1988, The geology and the drilling and production history of the Upper Devonian Shale of Breathitt, Clay, Johnson, Leslie, Magoffin, Perry, and Wolfe Counties, east-central Kentucky: Lexington, Kentucky, Kentucky Geological Survey, Gas Research Institute contract report, contract 5084-213-0990, 50 p.

Moody, J. R., Kemper, J. R., Johnston, I. M., Elkin, R. R., Smath, R. A., and Frankie, W. T., 1988, The geology and the drilling and production history of the Upper Devonian Shale of Boyd, Carter, Elliott, Greenup, Lawrence, Lewis, Menifee, Morgan, and Rowan Counties, north-eastern Kentucky: Lexington, Kentucky, Kentucky Geological Survey, Gas Research Institute contract report, contract 5084-213-0990, 37 p.

Moody, J. R., Kemper, J. R., Johnston, I. M., Frankie, W. T., and Elkin, R. R., 1987, Geologic and hydrocarbon report of Martin County: Part 4 of 5, Hydrocarbon production from the Devonian Shale in Letcher, Knott, Floyd, Martin, and Pike Counties, eastern Kentucky: Lexington, Kentucky, Kentucky Geological Survey, Gas Research Institute contract report, contract 5084213-0990, 50 p.

Moritis, G., 2001, New companies, infrastructure, projects reshape landscape for $\mathrm{CO}_{2}$ EOR in US: Oil \& Gas Journal, v. 99.20, no. 14-May-2001, p. 68-73.

Morse, D. G., 1995, Distribution and lithologic (organic) facies of the New Albany shale in the Illinois Basin, in Gas potential of the New Albany shale workshop, Evansville, Indiana, p. C1-C3, illustrated.

Morse, D. G., 1996, Sedimentology, diagenesis, and trapping style, Chesterian Tar Springs Sandstone at Inman Field, Gallatin County, Illinois: American Association of Petroleum Geologists Bulletin, Eastern Section Abstracts, v. 80, no. 9, p. 1528-1529.

Murray, J. B., 1971, Silurian and Lower Devonian deposition in the Southern Appalachian Mountains: a stratigraphic and environmental analysis [Thesis thesis]: Case Western Reserve University, 442 p.

Nadelhoffer, K. J., Emmett, B. A., Gundersen, P., Kjonaas, O. J., Koopmans, C. J., Schleppi, P., Tietema, A., and Wright, R. F., 1999, Nitrogen deposition makes a minor contribution to carbon sequestration in temperate forests: Nature, v. 398, no. 6723, p. 145-148. 
Negus-deWys, J., 1979, The eastern Kentucky gas field: a geological study of the relationships of Ohio Shale gas occurrences to structure, stratigraphy, lithology, and inorganic geochemical parameters, UGR file \#262: Morgantown, West Virginia, 199 p.

Nicholson, T. J., 1983, Geology and the accumulation of hydrocarbons in the "Big Lime" and Borden group (Mississippian) and Pre-Chattanooga (Silurian-Devonian of Knox, Laurel and Whitley Counties, south-east Kentucky [Thesis thesis]: University of Kentucky, unknown p.

Norby, R. D., and Ettensohn, F. R., 1992, Stratigraphy and biostratigraphy of the New Albany shale (Devonian-Mississippian) in the Illinois basin: American Association of Petroleum Geologists Bulletin, Eastern Section Abstracts, v. 76, no. 8, p. 1282.

Norman, C., 1994, $\mathrm{CO}_{2}$ for EOR is Plentiful But Tied to Oil Price: Oil \& Gas Journal, v. 92, no. 6, p. 4450 .

Nosow, E., 1962, Kentucky, in Research Committee of the Interstate Oil Compact Commission, ed., Underground Storage of Natural Gas in the United States: Oklahoma City, Oklahoma, Interstate Oil Compact Commission, p. 156-162.

Nuccio, V. F., 1994, Thermal history modeling in the Illinois Basin, in Ridgely, J. L., Drahovzal, J. A., Keith, B. D., and Kolata, D. R., eds., Proceedings of the Illinois Basin energy and mineral resources workshop: U. S. Geological Survey, Open-file report, p. 28-29.

Nuccio, V. F., and Hatch, J. R., 1994, Potential problems using vitrinite reflectance to calibrate thermal history models in the Illinois Basin: American Association of Petroleum Geologists and Society of Economic Paleontologists and Mineralogists, Annual Meeting Abstracts, p. 226.

Nuccio, V. F., and Hatch, J. R., 1996, Vitrinite reflectance suppression in the New Albany shale, Illinois Basin; vitrinite reflectance and Rock-Eval data, U. S. Geological Survey, Open-file report, 37 p.

O'Brien, N. R., Slatt, R. M., and Sneftle, J., 1993, The significance of oil shale fabric in primary hydrocarbon migration, in Lau, F. S., and Bonner, W. P., eds., 1992 Eastern oil shale symposium; proceedings: University of Kentucky, Institute for Mining and Minerals Research, Lexington KY, IMMR93-01, p. 294-299.

O'Hare, A. T., 1982, A geochemical study of the partitioning of elements during retorting of oil shales from Lewis County, Kentucky [Thesis thesis]: University of Kentucky, unknown p.

Oil and Gas Journal, 1998, Shell pressing $\mathrm{CO}_{2}$ flood initiative in Kansas: Oil and Gas Journal, September 28, 1998, v. 96, p. 40.

Oil and Gas Journal, 1999, Shell details Kansas $\mathrm{CO}_{2}$ flood project: Oil and Gas Journal, July 26, 1999, v. 97, p. $42-43$.

Oil and Gas Journal, 2000, Seismic surveys provide baseline for $\mathrm{CO}_{2}$ flood: Oil and Gas Journal, June 5, 2000 , v. 98 , no. 23 , p. 41.

Oil and Gas Journal, 2000, US greenhouse gas emissions growth slows: Oil and Gas Journal, v. 98, no. 7 (Feb. 14, 2000), p. 30-31.

Oltz, D. F., Crockett, J. E., Mast, R. F., Howard, R. H., Rupp, J. A., and Noger, M. C., 1992, Oil and gas potential in Paducah Quadrangle, in Goldhaber, M. B., and Eidel, J. J., eds.: U. S. Geological Survey, Open-file report, p. 42-43.

Orton, E., 1891, Report on the occurrence of petroleum, natural gas and asphalt rock in western Kentucky, based on examinations made in 1888 and 1889, Kentucky Geological Survey, Series 2, volume E, $233 \mathrm{p}$. 
Paquette, D. E., 1987, Depositional and diagenetic history of a Devonian coral and stromatoporoid biostrome, Falls of the Ohio River, Louisville, Kentucky [Thesis thesis]: Wright State University, $110 \mathrm{p}$.

Parson, E. A., and Keith, D. W., 1998, Fossil Fuels Without $\mathrm{CO}_{2}$ Emissions: Science, v. 282, no. 5391, p. 1053-1054.

Pashin, J. C., 1985, Paleoenvironmental analysis of the Bedford-Berea sequence (DevonianMississippian), north-eastern Kentucky and south-central Ohio [Thesis thesis]: University of Kentucky, unknown p.

Pashin, J. C., and McIntyre, M. R., In Press, Temperature-pressure conditions in coalbed methane reservoirs of the Black Warrior basin: implications for carbon sequestration and enhanced coalbed methane recovery: , p. 40.

Pearce, J. M., Holloway, S., Wacker, H., Nelis, M. K., Rochelle, C., and Bateman, K., 1996, Natural occurrences as analogues for the geological disposal of carbon dioxide: Energy Conservation and Management, v. 37, no. 6-8, p. 1123-1128.

Petroleum Tecnology Transfer Council, 1998, Shell initiates Kansas $\mathrm{CO}_{2}$ study, North Midcontinent Region of the Petroleum Technology Transfer Council.

Piccot, S. D., and Kirchgessner, D. A., 2000, EPA group verifies performance of greenhouse gas emissions-mitigation technologies: Oil and Gas Journal, August 28, 2000, v. 98, no. 35, p. 64-74.

Potter, P. E., 1978, Structure and isopach map of the New Albany-Chattanooga-Ohio shale (Devonian and Mississippian) in Kentucky, central sheet: Kentucky Geological Survey, Series 10, scale $1: 250,000$.

Potter, P. E., Maynard, J. B., and Pryor, W. A., 1980, Final report of special geological, geochemical, and petrological studies of the Devonian shales in the Appalachian Basin: Cincinnati, Ohio, H.N. Fisk Laboratory of Sedimentology, Department of Geology, University of Cincinnati, 86 p.

Potter, P. E., Maynard, J. B., and Pryor, W. A., 1981, Sedimentology of gas-bearing Devonian shales of the Appalachian basin: Cincinnati, Ohio, H.N. Fisk Laboratory of Sedimentology, Department of Geology, University of Cincinnati, 20 p.

President's Committee of Advisors on Science and Technology, 1997, Report to the President on federal energy research and development for the challenges of the twenty-first century, President's Committee of Advisors on Science and Technology, Panel on Energy Research and Development.

Pyron, A. J., Viellenave, J. H., and Fontana, J. V., 2003, New York Devonian black shale: a Barnett-like play in waiting: Oil and Gas Journal, v. 101.2, January 13, 2003, p. 36-42.

Quick, J. C., and Glick, D. C., 2000, Carbon dioxide from coal combustion: variation with rank of US coal: Fuel, v. 79, p. 803-812.

Ramaswamy, G., 2001, Production history provides CBM insights: Oil and Gas Journal, April 2, 2001, v. 99, no. 14, p. 49-52.

Ranganathan, V., 1992, Dissolved salt removal from Illinois Basin waters, in Kharaka, Y. K., and Maest, A. S., eds., Proceedings of the 7th international symposium on water-rock interaction; Volume 2, Moderate and high temperature environments: Edmonton, AB, International Association of Geochemistry and Cosmochemistry and Alberta Research Council Sub-group on Water-Rock Interaction, p. 1051-1054.

Ranganathan, V., 1992, Maintenance of high TDS in pore waters above the New Albany shale of the Illinois Basin: Geological Society of America, Abstracts with Programs, v. 24, no. 7, p. 324-325. 
Ranganathan, V., 1993, The maintenance of high salt concentrations in interstitial waters above the New Albany shale of the Illinois Basin: Water Resources Research, v. 29, no. 11, p. 3659-3670.

Ravizza, R., 1992, Applying the Re-Os and U-Th-Pb systems to black shale geochronology: International Geological Congress, Abstracts- Congress Geologique, International, Resumes, v. 29, p. 88.

Rawn-Schatzinger, V., 1999, $\mathrm{CO}_{2}$ Recovery from Flue Gas for Use in EOR: Eye On Envrionment (DOE's Oil \& Gas Environmental Research Program), v. 4, no. 1, p. 6-7.

Reeves, S., 2002, Field studies of enhanced methane recovery and $\mathrm{CO}_{2}$ sequestration in coal seams: World Oil, v. 223, no. 12, p. 56-60.

Reichle, D., Houghton, J., Kane, B., Ekmann, J., Benson, S., and al., e., 1999, Working Paper on Carbon Sequestration Science and Technology: U.S. Department of Energy.

Reynolds, D. W., Jr., 1997, Evidence for the presence of hydrocarbon charge in the Knox and pre-Knox rocks of the Rough Creek Graben [abs]: American Association of Petroleum Geologists Bulletin, Eastern Section and the Society for Organic Petrology meeting abstracts, v. 81, no. 9, p. 1562.

Reynolds, D. W., Jr., 1997, Reservoirs and hydrocarbons of the Narge Creek Block; anatomy of a field extension in a mature area: American Association of Petroleum Geologists Bulletin, Eastern Section and the Society for Organic Petrology meeting abstracts, v. 81, no. 9, p. 1662.

Rice, G. S., 1962, Silurian-Devonian stratigraphy of southern Madison, southern Garrard and eastern Lincoln Counties [Thesis thesis]: University of Kentucky, unknown p.

Ridgley, J. L., and Nuccio, V. F., 1994, Mississippian St. Louis Limestone; a new source-rock play in the Illinois Basin?: American Association of Petroleum Geologists and Society of Paleontologists and Mineralogists, Annual Meeting Abstracts, p. 243.

Roen, J. B., and Kepferle, R. C., 1993, Petroleum Geology of the Devonian and Mississippian Black Shale of eastern North America, U. S. Geological Survey Bulletin 1909.

Roth, G., 1983, Sheep Mountain and Dike Mountain fields, Huerfano County, Colorado; a source of $\mathrm{CO}_{2}$ for enhanced oil recovery, in Fassett, J. E., ed., Oil and gas fields of the Four Corners area, Four Corners Geological Society, p. 740-744.

Rubarts, W. E., 1959, the Boyle-Duffin-New Albany relationships in northern Casey and western Lincoln Counties [Thesis thesis]: University of Kentucky, unknown p.

Rudnicki, J. W., and Wawersik, W. R., 1999, Report looks at sequestering $\mathrm{CO}_{2}$ beneath Earth's surface: Eos, Transactions, American Geophysical Union, v. 80, no. 50, p. 607-608.

Runge, E. J., 1959, An analysis of the microfauna of the Kiddville layer of the Devonian Boyle Limestone, Marion County, Kentucky [Thesis thesis]: Miami University, 86 p.

Rushing, S. A., 1994, $\mathrm{CO}_{2}$ Recovery Improves Cogen Plant Economics: Power Engineering, v. 98, no. 4, p. 46-47.

Rushing, S. A., 1995, Business Opportunity: Power Projects Profit from $\mathrm{CO}_{2}$ Recovery: Electrical World, v. 209 , no. 3 , p. 48.

Rutledge, H. M., 1957, The Boyle Formation of southern Boyle County, Kentucky [Thesis thesis]: University of Kentucky, unknown p.

Ryder, R. T., Burruss, R. C., and Hatch, J. R., 1998, Black shale source rocks and oil generation in the Cambrian and Ordovician of the Central Appalachian Basin, USA: AAPG Bulletin, v. 82, no. 3, p. 412-441. 
Salkever, A., 1999, Turning the Ocean into a Giant Soda Pop, The Christian Science Monitor: Boston, MA, p. 2.

Salmon, G. L., Risatti, J. B., and Whitaker, S. T., 1992, Geochemical characterization of dissimilarsourced oils from upper Knox and Middle Devonian rocks, Wayne County, Illinois: American Association of Petroleum Geologists Bulletin, Eastern Section Abstracts, v. 76, no. 8, p. 1284.

Sandararaman, P., and Robl, R. I., 1993, Use of activation energy of maceral concentrate in predicting product composition of generated oil: American Association of Petroleum Geologists and Society of Economic Paleontologists and Mineralogists, Annual Meeting Abstracts, p. 187.

Sandberg, C. A., Hasenmueller, N. R., and Rexroad, C. B., 1993, Conodont zonation, biofacies, and correlations of lower part of New Albany shale (Devonian), central and southern Indiana: Geological Society of America, North-Central Section, Abstracts with Programs, v. 25, no. 3, p. 77.

Sandberg, C. A., Hasenmueller, N. R., and Rexroad, C. B., 1994, Conodont biochronology, biostratigraphy, and biofacies of Upper Devonian part of New Albany shale, Indiana: CourierForschungsinstitut Senckenberg, v. 168, p. 227-253.

Sargent, M. L., Rupp, J. A., and Noger, M. C., 1992, Structure and morphology of the top of Precambrian crystalline rocks in the Illinois Basin region: Geological Society of America, Abstracts with Programs, v. 24, no. 7, p. 178.

Sasaki, A., Matsumoto, S., Fujitsuka, M., Shinoki, T., Tanaka, T., and Ohtsuki, J., 1993, $\mathrm{CO}_{2}$ Recovery in Molten Carbonate Fuel Cell System by Pressure Swing Adsorption: IEEE Transactions on Energy Conversion, v. 8, no. 1, p. 26-32.

Schieber, J., 1996, Early diagenetic silica deposition in algal cysts and spores; a source of sand in black shales?: Journal of Sedimentary Research, Section A: Sedimentary Petrology and Processes, v. 66, no. 1, p. 175-183.

Schoeling, L., 1999, Enhanced coalbed methane production with carbon dioxide injection [abs], in Interstate Oil and Gas Compact Commission Annual Meeting Presentation Notes, New Orleans.

Schoeling, L., and Fox, C. E., 1998, $\mathrm{CO}_{2}$ floods look good in Mid-Continent, Shell $\mathrm{CO}_{2}$.

Schoeling, L. G., Green, D. W., and Poyser, L. A., A Survey of Waterflooding Performance, LansingKansas City/ $\mathrm{CO}_{2}$ Potential: , p. 95-109.

Schulmeister, M. K., 1993, A study of the first row transition elements as a group in a section of the New Albany shale (Devonian- Mississippian) of southern Indiana [Masters Thesis thesis]: Michigan State University, 99 p.

Schultz, R. B., 1991, Metalliferous black shales; accumulation of carbon and metals in cratonic basins, in Force, E. R., Eidel, J. J., and Maynard, J. B., eds., Sedimentary and diagenetic mineral deposits; a basinal analysis approach to exploration: Society of Economic Geologists, Reviews in Economic Geology volume 5, p. 171-176.

Schütz, M., Daun, M., Weinspach, P.-M., Krumbeck, M., and Hein, K. R. G., 1992, Study on the $\mathrm{CO}_{2^{-}}$ Recovery from an ICGCC Plant: Energy Conversion and Management, v. 33, no. 5-8, p. 357-363.

Schwalb, H., and Norris, R. L., 1980, East-west cross sections north and south of Rough Creek Fault system: United States Department of Energy, Morgantown Energy Technology Center, Eastern Gas Shales Project, METC/EGSP Series 900, scale 2 sheets.

Schwalb, H., and Norris, R. L., 1980, Isopach map of Blocher member of New Albany shale, western Kentucky: United States Department of Energy, Morgantown Energy Technology Center, Eastern Gas Shales Project, METC/EGSP Series 902, scale 1:500,000. 
Schwalb, H., and Norris, R. L., 1980, Isopach map of Grassy Creek member of New Albany shale, western Kentucky: United States Department of Energy, Morgantown Energy Technology Center, Eastern Gas Shales Project, METC/EGSP Series 905, scale 1:500,000.

Schwalb, H., and Norris, R. L., 1980, Isopach map of Sweetland Creek member of New Albany shale, western Kentucky: United States Department of Energy, Morgantown Energy Technology Center, Eastern Gas Shales Project, METC/EGSP Series 903, scale 1:500,000.

Schwalb, H., and Norris, R. L., 1980, North-south cross section east side of area: United States Department of Energy, Morgantown Energy Technology Center, Eastern Gas Shales Project, METC/EGSP Series 904, scale 2 sheets.

Schwalb, H., and Norris, R. L., 1980, North-south cross section west side of area: United States Department of Energy, Morgantown Energy Technology Center, Eastern Gas Shales Project, METC/EGSP Series 901, scale 2 sheets.

Schwalb, H., and Norris, R. L., 1980, Occurrence of natural gas in the New Albany shale, western Kentucky: United States Department of Energy, Morgantown Energy Technology Center, Eastern Gas Shales Project, METC/EGSP Series 906, scale 1:500,000.

Schwalb, H., and Norris, R. L., 1980, Structure map on the base of the new Albany shale, western Kentucky: United States Department of Energy, Morgantown Energy Technology Center, Eastern Gas Shales Project, METC/EGSP Series 907, scale 1:500,000.

Schwalb, H. R., and Potter, P. E., 1978, Structure and isopach map of the New Albany-Chattanooga-Ohio shale (Devonian and Mississippian) in Kentucky, western sheet: Kentucky Geological Survey, Series 10 , scale 1:250,000.

Shell CO2, 1998, CO2 floods may enhance Kansas oilfield recovery, Shell CO2.

Shell CO2, 1999, What is a CO2 flood?, Shell CO2.

Shirley, A. I., 1994, Comments on "Concentration and Recovery of CO2 from Flue Gas by Pressure Swing Adsorption": Industrial \& Engineering Chemistry Research, v. 33, no. 11, p. 2879-2880.

Shumaker, R. C., 1987, Structural parameters that affect Devonian shale gas production in West Virginia and eastern Kentucky, Appalachian Basin Industrial Associates, 133-201 p.

Shumaker, R. C., 1993, Structural parameters that affect Devonian shale gas production in West Virginia and eastern Kentucky, in Roen, J. D., and Kepferle, R. C., eds., Petroleum geology of the Devonian and Mississippian black shale of eastern North America, U. S. Geological Survey Bulletin 1909, p. K1-K38.

Skinner, L., 2003, CO2 blowouts: an emerging problem: World Oil, v. 224, no. 1, p. 38-42.

Smidchens, Z., Boberg, W. S., Frankie, W. T., Lumm, D. K., and Hamilton-Smith, T., 1994, Map showing locations of cores of the New Albany shale (Devonian and Mississippian) in the Illinois Basin, in Hasenmueller, N. R., and Comer, J. B., eds., Gas potential of the New Albany shale (Devonian and Mississippian) in the Illinois Basin: Illinois Basin Consortium, Gas Research Institute 92-0391/Illinois Basin Studies 2, plate 2, scale 1:1,000,000.

Sneftle, J. T., Yordy, K. L., Barron, L. S., and Crelling, J. C., 1991, Whole rock and isolated kerogen characterization studies; observations of sample type preparations upon petrographic and chemical characterization of New Albany shale, in Baker, E. W., and Douglas, A. G., eds., Organic Geochemistry: Collected papers from the Fifth annual meeting of the Society for Organic Petrology and the Society for Organic Petrology/ American Association of Stratigraphic Palynologists symposium, p. 275. 
Spirakis, C. S., 1995, Problems with applying topographically driven flow to genesis of the Upper Mississippi Valley zinc-lead district and to fluid flow in the Illinois Basin, U. S. Geological Survey Bulletin 2094-C, 12 p.

Stankiewicz, B. A., 1995, Geochemistry and petrology of coal and kerogen macerals [PhD Dissertation thesis]: Southern Illinois University, 272 p.

Stephens, S. H., and Gale, J., 2000, Geologic $\mathrm{CO}_{2}$ sequestration may benefit upstream industry: Oil \& Gas Journal, v. 98, no. 20, p. 40-44.

Stephenson, J. T., 1979, Petrology, lithofacies and depositional analysis of the Boyle dolomite, Middle Devonian in east-central Kentucky [Thesis thesis]: University of Cincinnati, unknown p.

Stevens, S. H., Schoeling, L., and Pekot, L., 1999, $\mathrm{CO}_{2}$ Injection for enhanced colbed methane recovery: project screening and design, in University of Alabama, C. o. C. S., ed., Proceedings of the 1999 International Coalbed Methane Symposium: Tuscaloosa, AL, University of Alabama, p. 309-318.

Stevens, S. H., Spector, D., and Riemer, P., 1998, Enhanced coalbed methane recovery using $\mathrm{CO}_{2}$ injection: Worldwide resource and $\mathrm{CO}_{2}$ sequestration potential: Society of Petroluem Engineers, SPE 48881, p. 489-501.

Suda, T., Fujii, M., Yoshida, K., Iijima, M., Seto, T., and Mitsuoka, S., 1992, Development of Flue Gas Carbon Dioxide Recovery Technology: Energy Conversion and Management, v. 33, no. 5-8, p. 317-324.

Swager, D. R., 1978, Stratigraphy of the Upper Devonian-Lower Mississippian shale sequence in the Eastern Kentucky outcrop belts [Thesis thesis]: University of Kentucky, unknown p.

Takano, S.-I., Kiga, T., Endo, Y., Miyamae, S., and Suzuki, K., 1995, $\mathrm{CO}_{2}$ Recovery from PCF Power Plant with $\mathrm{O}_{2} / \mathrm{CO}_{2}$ Combustion Process: Ihi Engineering Review, v. 28, no. 4, p. 160-164.

Talmage, S. B., and Andreas, A., 1942, Carbon dioxide in New Mexico, in Bates, R. L., ed., The oil and gas resources of New Mexico (2nd ed), New Mexico Bureau of Mines and Mineral Resources Bulletin 18, p. 301-307.

Teng, H. H., Dove, P. M., DeYoreo, J. J., and Orme, C., 1998, Thermodynamic controls on calcite growth; determining foundations of biomineral formation: Abstracts with Programs Geological Society of America, v. 30, no. 7, p. 156.

The Society for Organic Petrology, 1998, Coalbed Methane (full list).

Thomas, Jr., Josephus, and Frost, R. R., 1980, Adsorption/Desorption Studies of Gases through Shales, in Bergstrom, R. E., Shimp, N. F., and Cluff, R. M., eds., Geologic and Geochemical Studies of the New Albany Shale Group (Devonian-Mississippian) in Illinois, Final Report: Urbana, Illinois, Illinois State Geological Survey, DOE/METC/12142-26, p. 143-183.

Thomas, R. N., 1951, Devonian shale gas production in central Appalation area: Lexington, Kentucky, Kentucky Geological Survey, Series 9, Reprint 4, 8 p.

Tontiwachwuthikul, P., Chan, C. W., Kritpiphat, W., DeMontigny, D., Skoropad, D., Gelowitz, D., Aroonwilas, A., Mourits, F., Wilson, M., and Ward, L., 1998, Large Scale Carbon Dioxide Production from Coal-Fired Power Plants for Enhanced Oil Recovery: A New Economic Feasibility Study: Journal of Canadian Petroleum Technology, v. 37, no. 11, p. 48-55.

Tontiwachwuthikul, P., Chan, C. W., Kritpiphat, W., Jordan, C., Skoropad, D., Gelowitz, D., Aroonwilas, A., Mourits, F., Wilson, M., and Ward, L., 1996, Carbon Dioxide Production from Coal-Fired Power Plants for Enhanced Oil Recovery: A Feasibility Study in Western Canada: Energy, v. 21, no. 10 , p. 857-869. 
Tontiwachwuthikul, P., Chan, C. W., Kritpiphat, W., Skoropad, D., Gelowitz, D., Aroonwilas, A., and Jordan, C., 1996, New feasibility study of carbon doxide production from coal-fired power plants for enhanced oil recovery: a Canadian perspective: Energy Conservation and Management, v. 37, no. 6-8, p. 1129-1134.

Treworgy, C. G., Prussen, E. I., Justice, M. A., Chenoweth, C. A., Bargh, M. H., Jacobson, R. J., and Damberger, H. H., 1997, Illinois coal reserve assessment and database development: final report: Champaign, Illinois, Illinois State Geological Survey, Open File Series 1997-4, 105 p.

Turner, J. A., 1999, A Realizable Renewable Energy Future: Science, v. 285, no. 5427, p. 687-689.

U. S. Department of Energy, 1993, $\mathrm{CO}_{2}$ Prophet: water and $\mathrm{CO}_{2}$ flood prediction software, Texaco Exploration and Production Technology Department (DOE Contract No. DE-FC22-93BC14960).

U. S. Department of Energy, O. o. S., 1999, Carbon sequestration: State of the science, U.S. Department of Energy, various p.

Vella, A. J., and Holzer, G., 1992, Distribution of isoprenoid hydrocarbons and alkylbenzenes in immature sediments; evidence for direct inheritance from bacterial/algal sources: Organic Geochemistry, v. 18, no. 2, p. 203-210.

Vergano, D., 2000, Defusing the Carbon Dioxide Threat, USA Today, p. 9D.

Waku, H., Tamura, I., Inoue, M., and Akai, M., 1995, Life Cycle Analysis of Fossil Power Plant with $\mathrm{CO}_{2}$ Recovery and Sequestering System: Energy Conversion and Management, v. 36, no. 6-9, p. 877-880.

Walter, L. M., Budai, J. M., Martini, A. M., Richards, J. C., and Abriola, L. M., 1995, Geology and hydrogeochemistry of the Michigan Basin with implications for exploration in the New Albany shale, in Gas potential of the New Albany shale workshop, Evansville, Indiana, p. H1, illustrated.

Wawersik, W. R., and Rudnicki, J. W., 1998, Terrestrial sequestion of $\mathrm{CO}_{2}$-An assessment of research needs: Washington, D.C., U. S. Department of Energy, Office of Science,, p. 67.

Welch, R. N., 1937, A study and description of two cores from the "Corniferous" of western Powell County, Kentucky [Thesis thesis]: University of Kentucky, unknown p.

Wells, B. E., and Mills, J. G., Jr., 1992, Orientation of principle paleostress directions in Mississippian strata of Warren County, Illinois, Kistler Quarry and Biggsville Quarry: Geological Society of America, North-Central Section, Abstracts with Programs, v. 24, no. 4, p. 71.

Wilson, M. A., Wrubleski, R. M., and Yarborough, L., 1992, Recovery of $\mathrm{CO}_{2}$ from Power Plant Flue Gases Using Amines: Energy Conversion and Management, v. 33, no. 5-8, p. 325-331.

Wojick, D. E., 1999, Carbon storage in soil, the ultimate no-regrets policy?, Greening Earth Society.

Wolsky, A. M., Daniels, E. J., and Jody, B. J., 1991, Recovering $\mathrm{CO}_{2}$ from Large- and Medium-Size Stationary Combustors: Journal of the Air \& Waste Management Association, v. 41, no. 4, p. 449-454.

Woock, R. D., 1982, The quantitative mineralogy and mineral stratigraphy of the Late-Devonian, EarlyMississippian black shales of east-central Kentucky [Thesis thesis]: University of Kentucky, unknown p.

Zaback, D. A., and Pratt, L. M., 1992, Clarification of C-S relationships of marine black shales using stable isotopic composition of reduced sulfur: Geological Society of America, Abstracts with Programs, v. 24, no. 7, p. 168.

Zuber, M. D., 1995, Production characteristics and practices, in Gas potential of the New Albany shale workshop, Evansville, Indiana, p. J1, illustrated. 


\section{Appendix A: Summary of Adsorption Isotherms}

The classic theory used to describe the Type I isotherm for microporous materials with small external surface area is based on the Langmuir equation (1916). The Type I isotherm displays a steep increase in adsorption at low relative pressures due to enhanced adsorption caused by the overlapping adsorption potentials between the walls of pores whose diameters are commensurate in size with the adsorbate molecule. The type I isotherm then flattens out into a plateau region at higher relative pressure, which is believed to be due to the completion of a monolayer of adsorbed gas. The micropore volume is then thought to be filled by only a few molecular layers of adsorbate, and further uptake is limited by the dimensions of the micropores.

The Langmuir model assumes that a state of dynamic equilibirum is established between the adsorbate vapor and the adsorbent surface and that adsorption is restricted to a single monolayer. The adsorbend surface is thought to be composed of a regular array of energetically homogeneous adsorption sites upon which an adsorbed monolayer is assumed to form. The rate of condensation is assumed to be equal to the rate of evaporation from the adsorbed monolayer at a given relative pressure and constant temperature. The Langmuir equation was developed with these assumptions and takes the following form:

$$
\frac{P}{V}=\frac{1}{B V_{m}}+\frac{P}{V_{m}}
$$

where $P$ is the equilibrium pressure, $V$ is the volume of gas adsorbed at equilibrium, $V_{m}$ is the volume of adsorbate occupying the monolayer and $B$ is an empirical constant. A plot of $P / V v s$ relative pressure should yield a straight line whose slope will yield $V_{m}$ from which the surface area may be obtained. As shown on the following figures, a best fit Langmuir isotherm and the data points have been plotted for each sample.

The Langmuir Isotherm can be written:

$$
V(P)=\frac{V_{L} P}{P_{L}+P}
$$

$P \quad=$ gas pressure

$V(P) \quad=$ predicted amount of gas adsorbed at $P$

$V_{L} \quad=$ Langmuir volume parameter

$P_{L} \quad=$ Langmuir pressure parameter

The difference between the measured amount of gas adsorbed $(V(P))$ and that predicted using the Langmuir Equation $\left(V_{i}(P)\right)$ is a measure of error and is given as:

$$
\operatorname{Err}(P)=V_{i}(P)-V(P)
$$


This error may be positive or negative. The square of the error is always positive and is a measure of how well the calculated isotherm matches the data. This error can be calculated for each point and summed giving a measure of the overall error:

$$
S S E=\sum_{i=1}^{N} E r r_{i}^{2}
$$

$N \quad=$ number of measured points

The goodness of fit of the isotherm is expressed by calculating the correlation coefficient between the measured points and the calculated points. The results generally yield correlations that are better than $r^{2}=$ 0.99 , and standard errors of Langmuir volumes of $\pm 2 \%$. The errors for the samples are found at the bottom of the datasheets included with each sample.

\section{References}

ICCP (International Committee for coal and Organic Petrology), 1998, The new vitrinite classification (ICCP System, 1994): Fuel, vol. 77, p. 349-358.

Langmuir, I., 1916, The constitution and fundamental properties of solids and liquids: Journal of the American Chemical Society, 38:2221-2295. 
107928-1 3600-4000 ft. Ohio Shale (upper part)

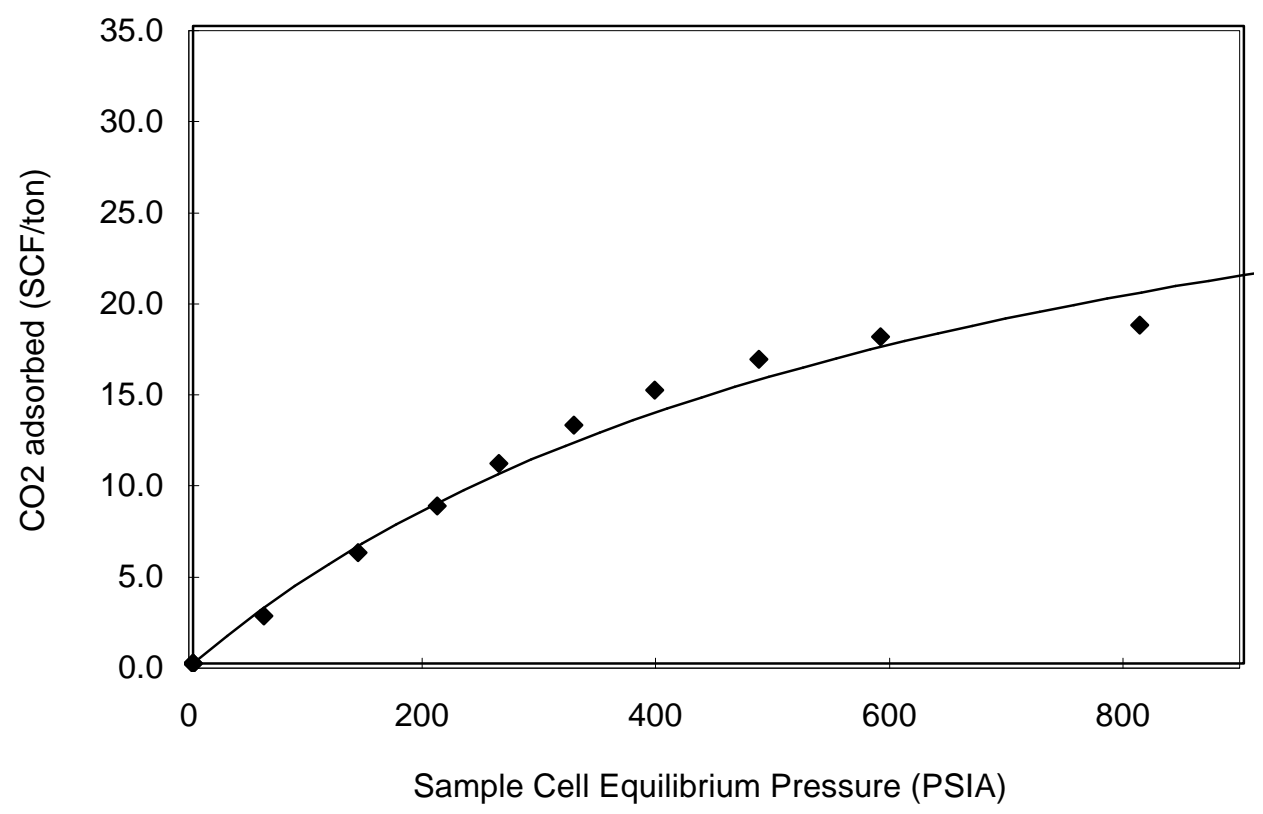

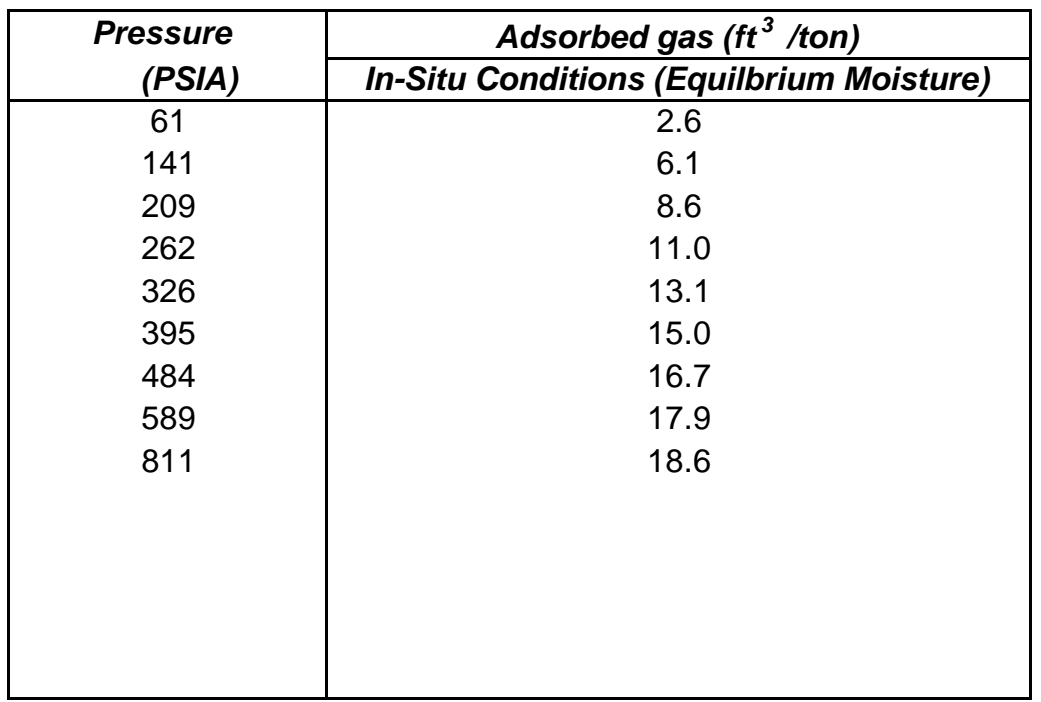

Langmuir Parameters

\begin{tabular}{|l|c|}
\hline & In-Situ Conditions (Equilbrium Moisture) \\
\hline Vol. (ft ${ }^{3} /$ ton) & 37.5 \\
Pressure (PSIA) & 681.1 \\
\hline
\end{tabular}

SUMMARY OF ADSORPTION ANALYSES IMP. UNITS Isotherm Temperature:

Goodness of fit of Langmuir regression:

86.0 ㅇ

0.88 Density $\mathrm{g} / \mathrm{cc} \quad 2.756$ 
107928-2 4400-4600 ft. Lower Huron Member

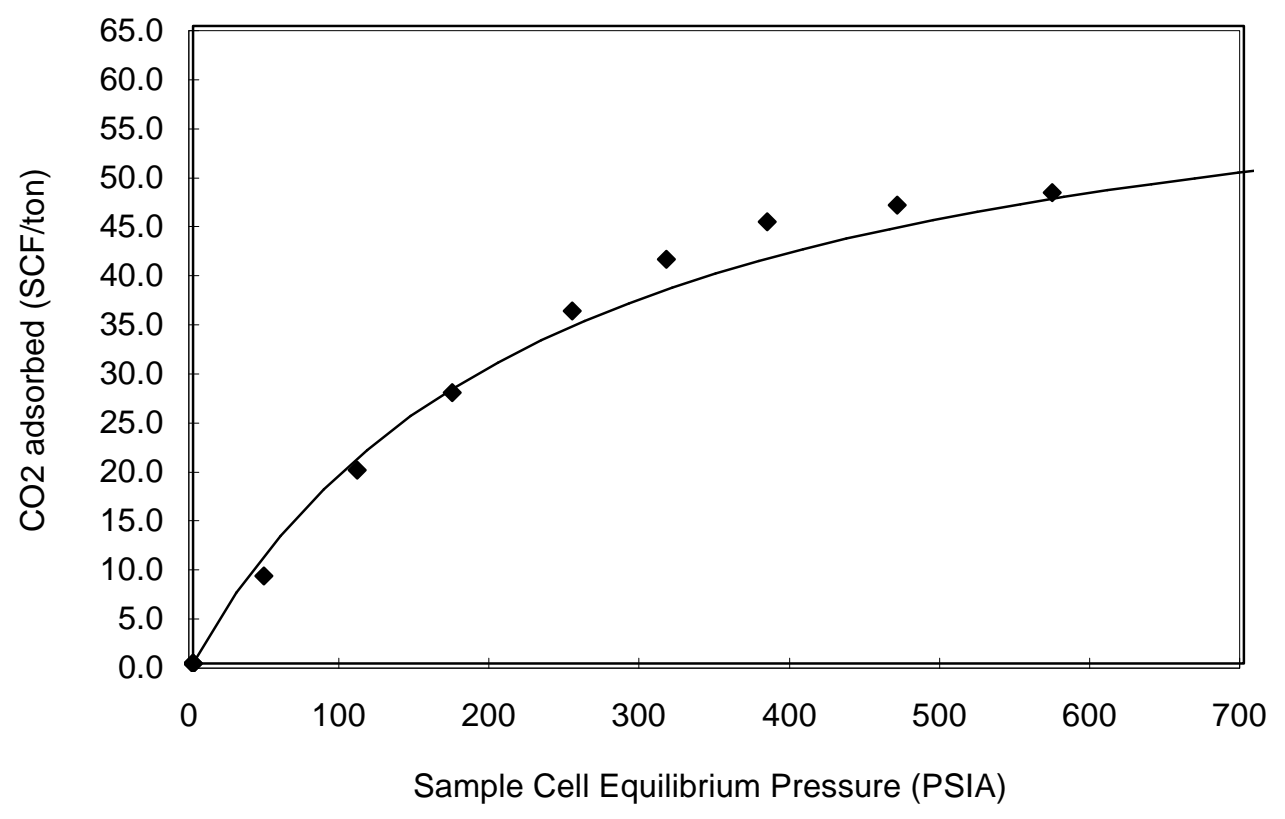

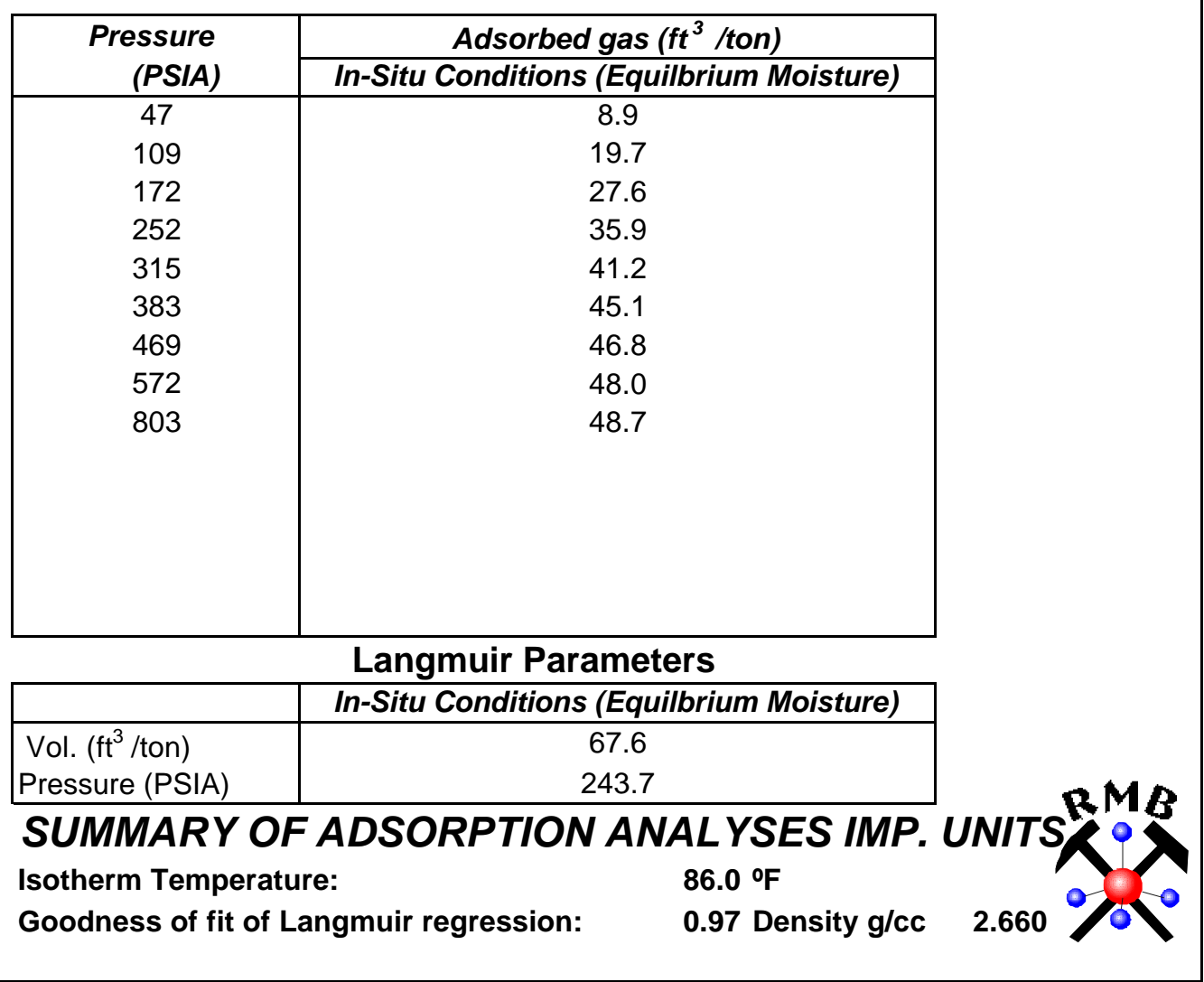




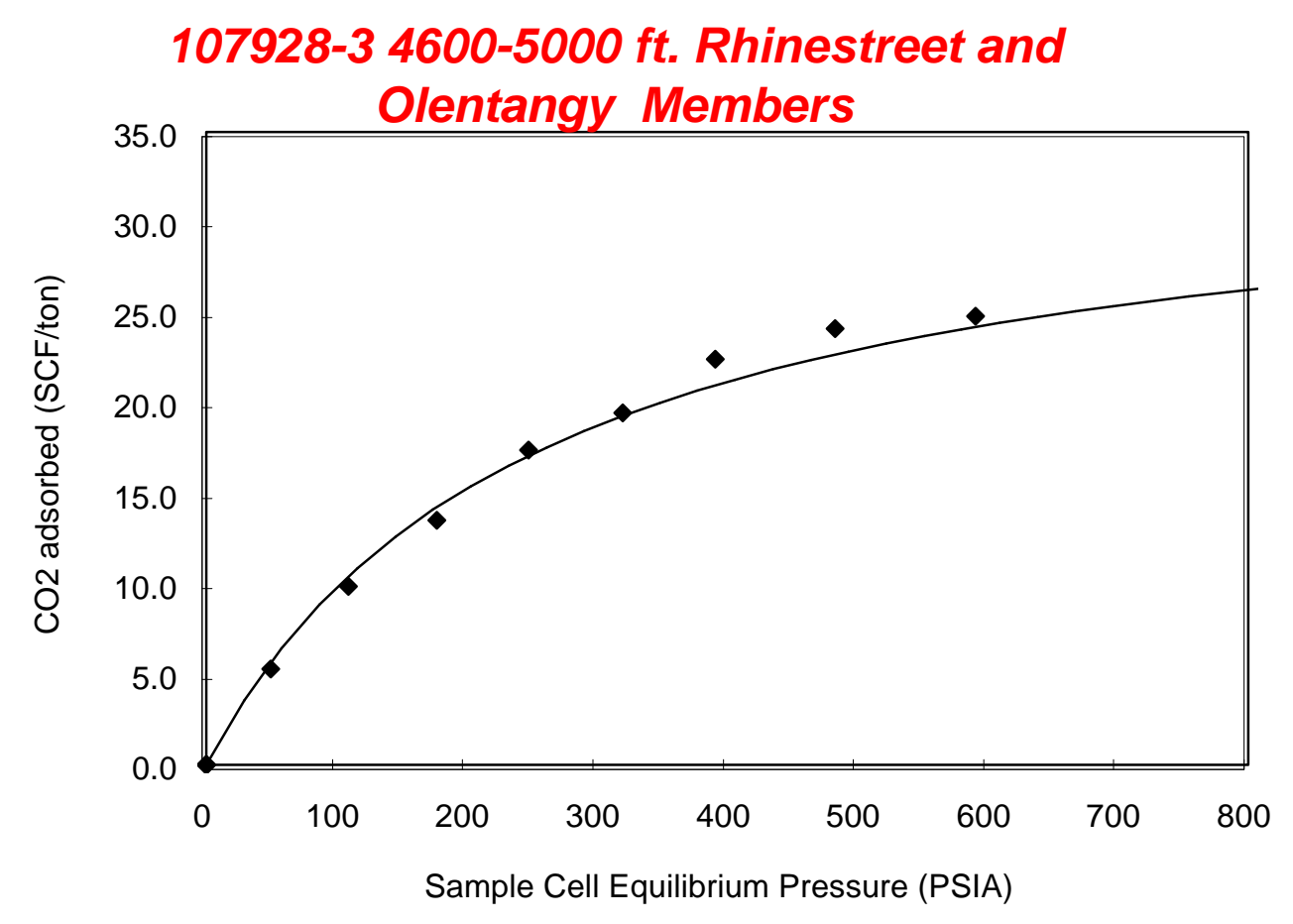

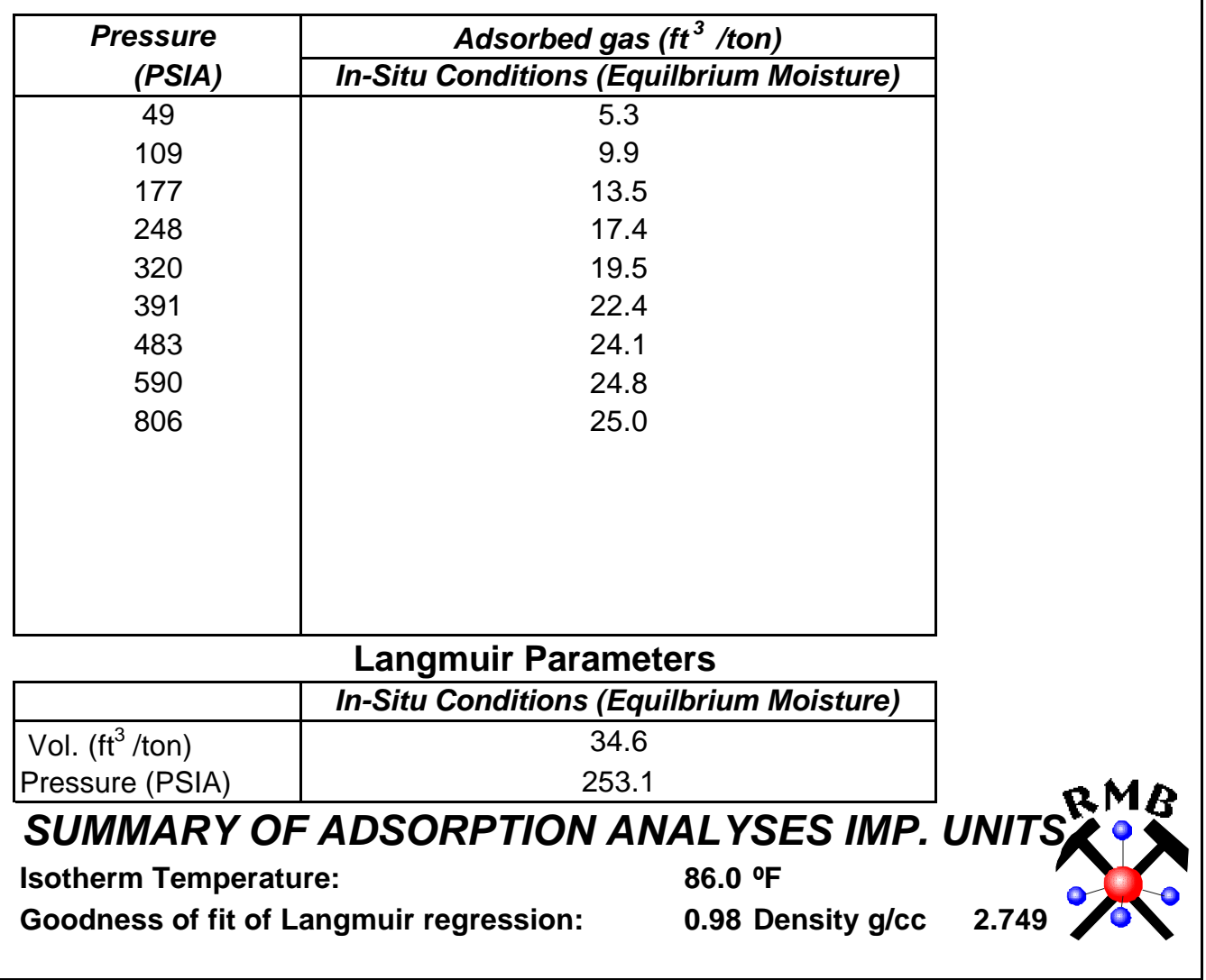




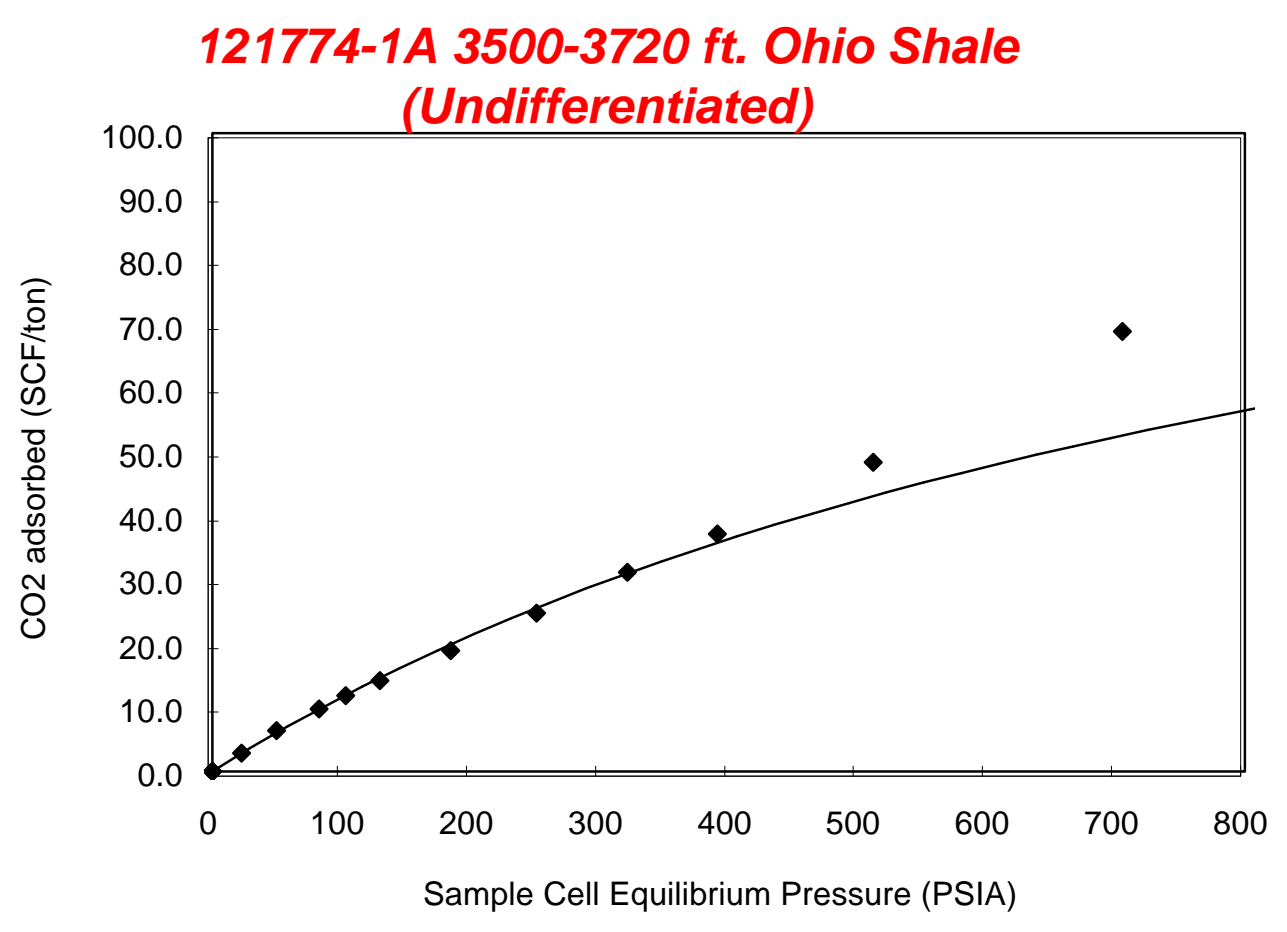

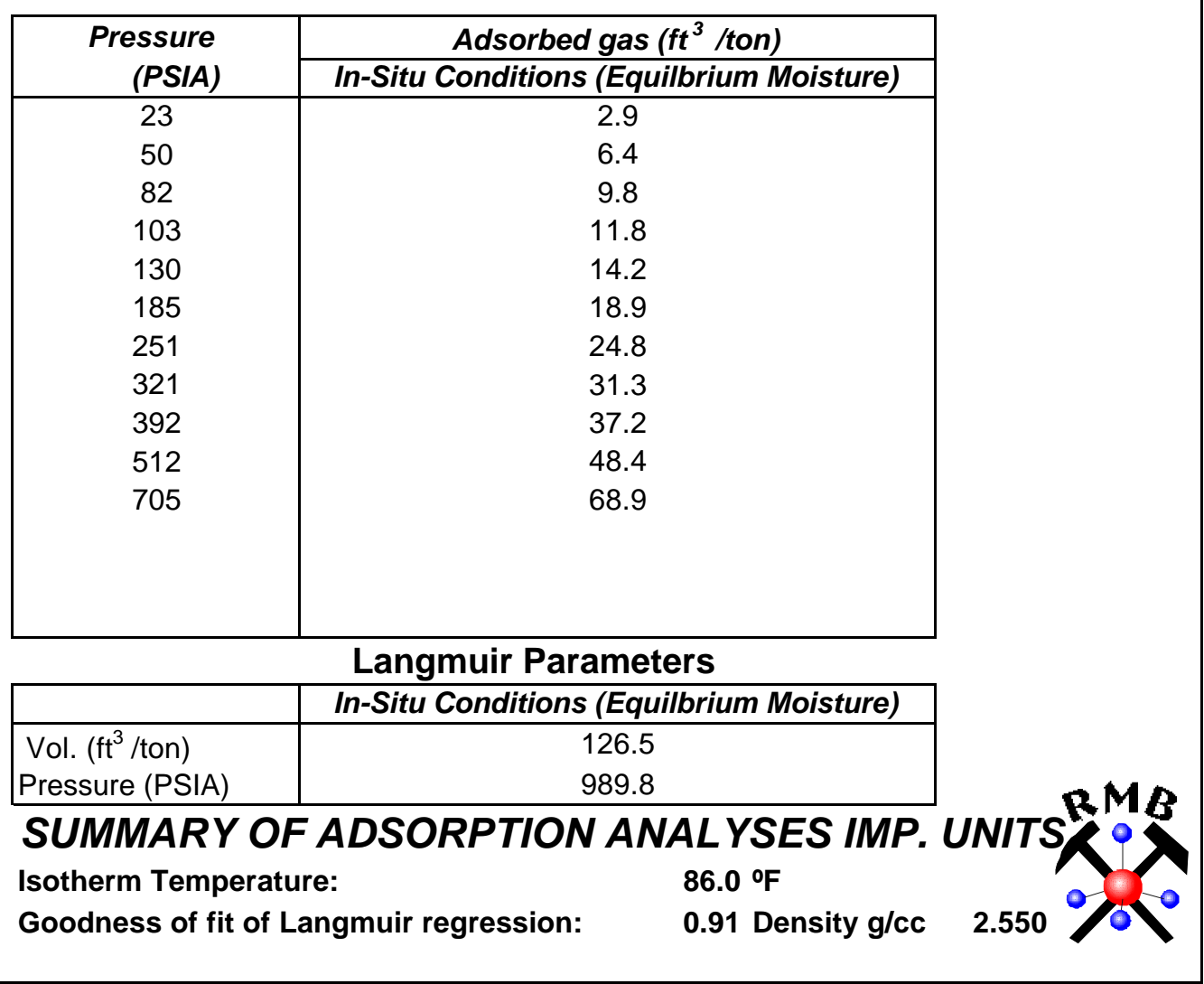




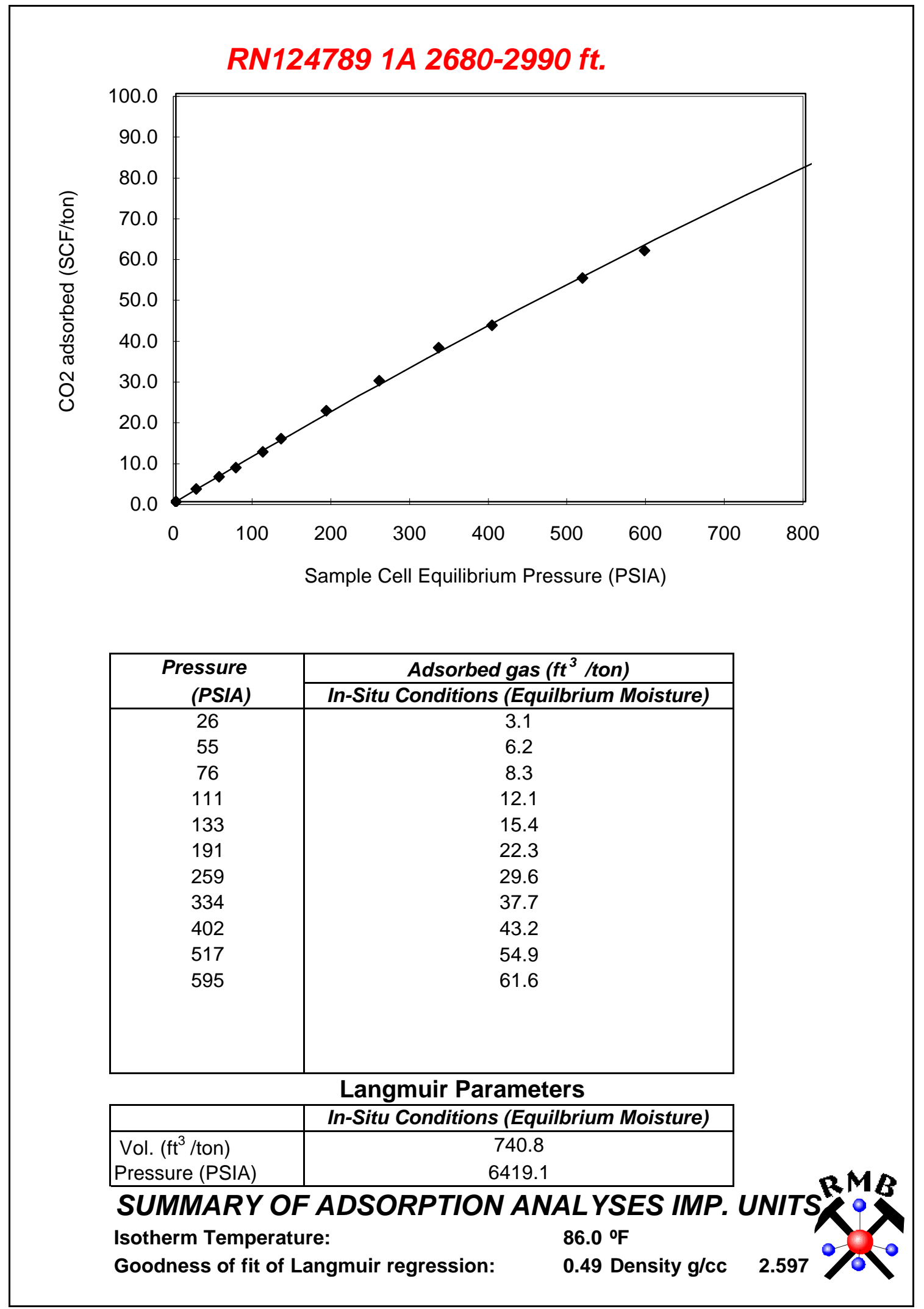


RN124789 S2A 2990-3110 ft.

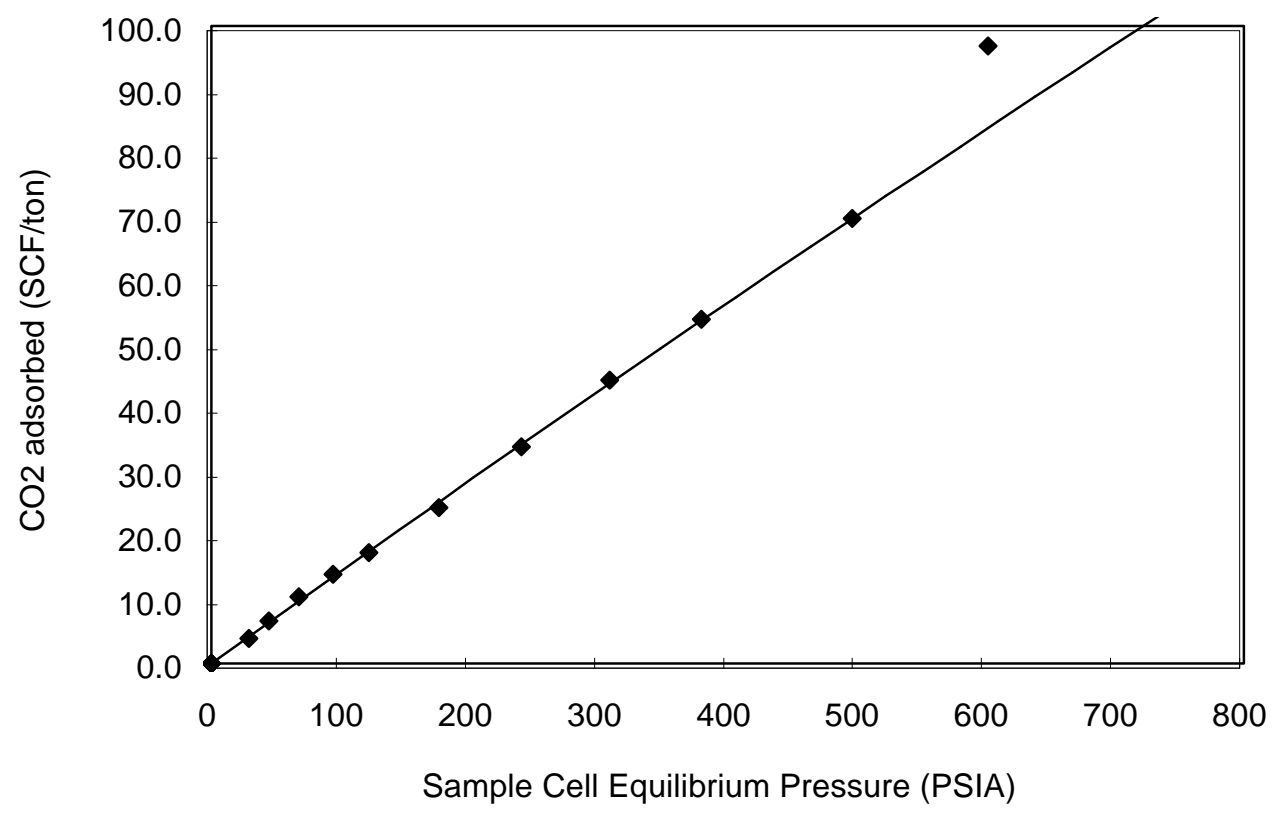

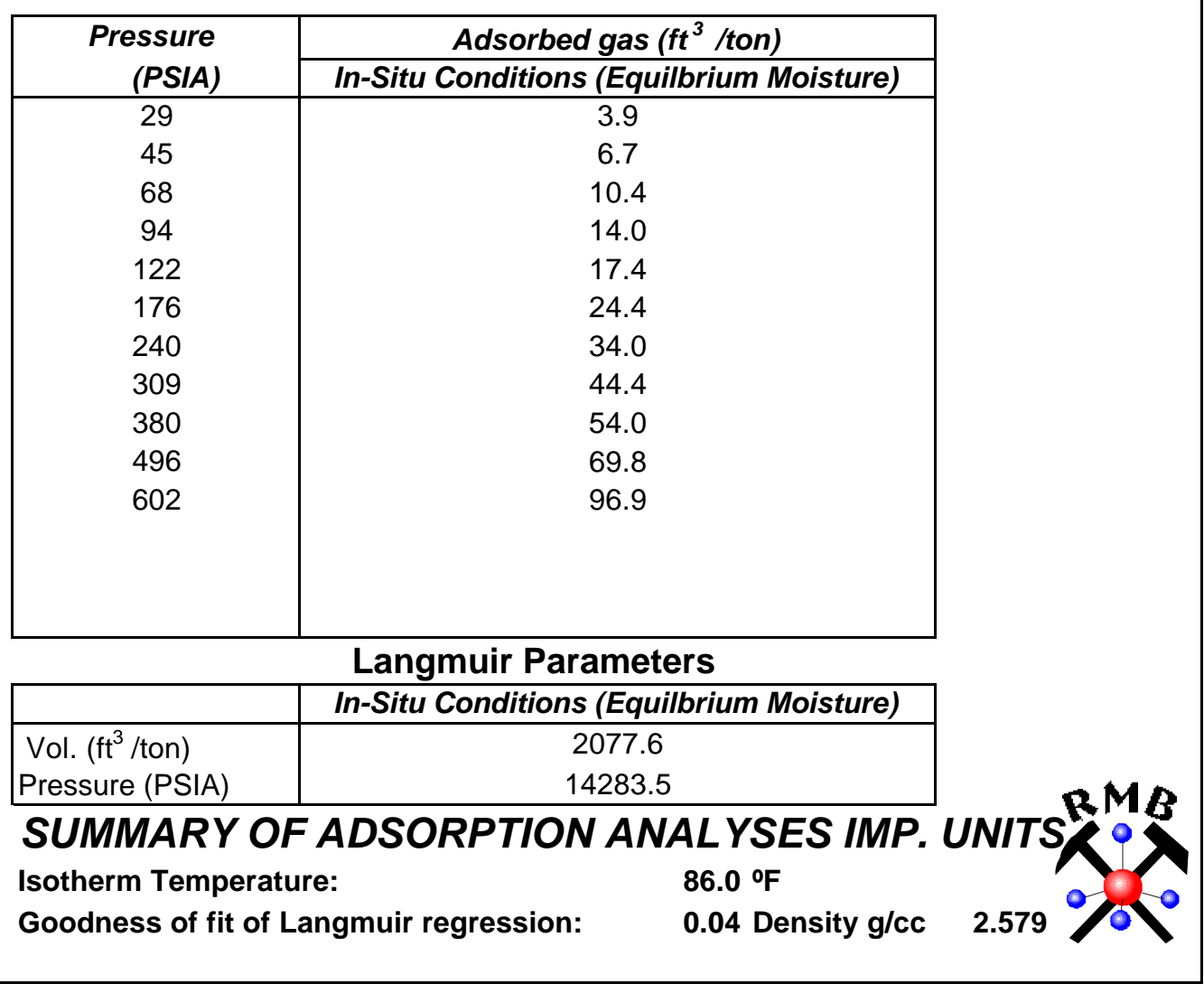


RN124789 3A 3110-TD

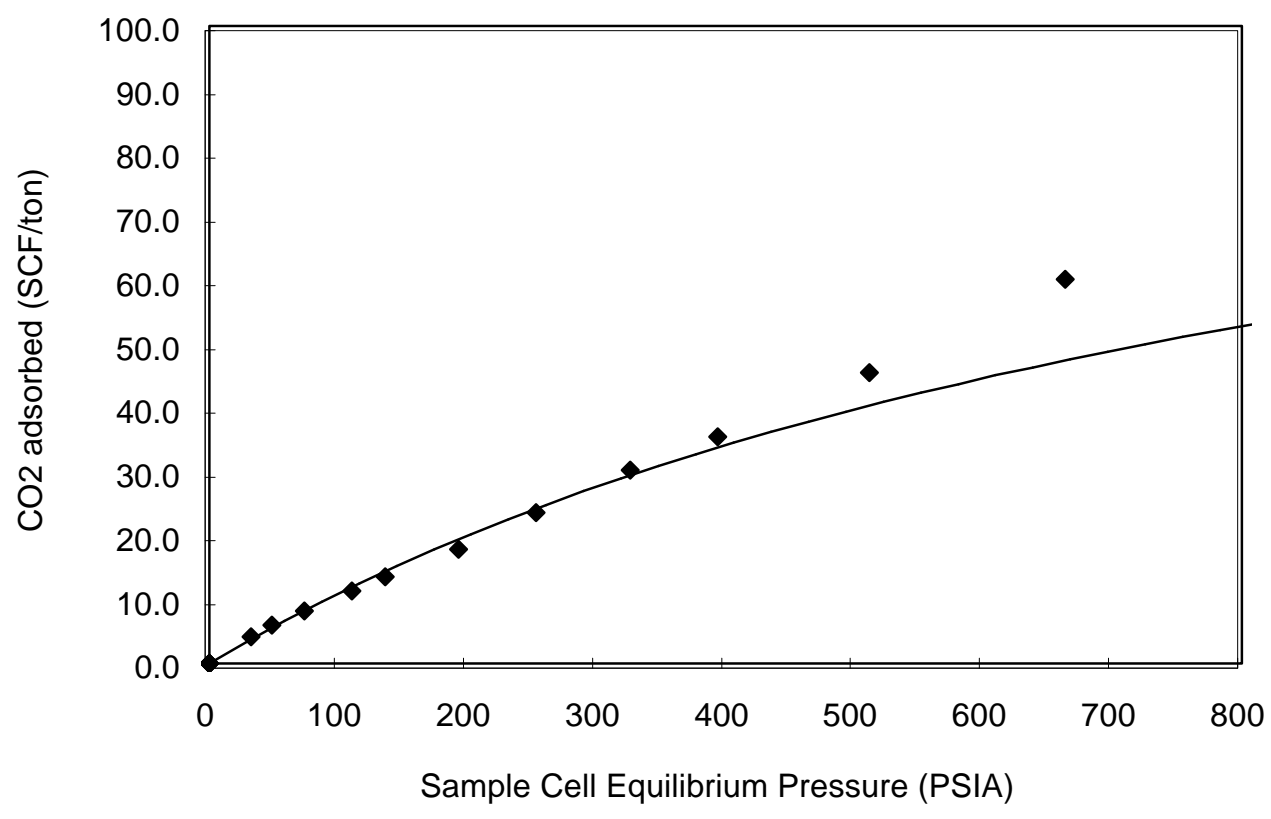

\begin{tabular}{|c|c|c|}
\hline \multirow{2}{*}{$\begin{array}{r}\text { Pressure } \\
\text { (PSIA) }\end{array}$} & Adsorbed gas ( $\left.\mathrm{ft}^{3} / \mathrm{ton}\right)$ & \\
\hline & In-Situ Conditions (Equilbrium Moisture) & \\
\hline 32 & 4.2 & \\
\hline 49 & 6.0 & \\
\hline 74 & 8.2 & \\
\hline 110 & 11.4 & \\
\hline 136 & 13.6 & \\
\hline 193 & 17.9 & \\
\hline 253 & 23.6 & \\
\hline 326 & 30.4 & \\
\hline 394 & 35.6 & \\
\hline 512 & 45.7 & \\
\hline 663 & 60.3 & \\
\hline \multicolumn{2}{|r|}{ Langmuir Parameters } & \\
\hline & In-Situ Conditions (Equilbrium Moisture) & \\
\hline \begin{tabular}{|l} 
Vol. (ft \\
3
\end{tabular} & 116.2 & \\
\hline Pressure (PSIA) & 957.9 & \\
\hline \multicolumn{3}{|c|}{ SUMMARY OF ADSORPTION ANAL YSES IMP. UNITS } \\
\hline $\begin{array}{l}\text { Isotherm Tempe } \\
\text { Goodness of fit }\end{array}$ & $\begin{array}{l}86.0{ }^{\circ} \mathrm{F} \\
0.77 \text { Density } \mathrm{q} / \mathrm{cc}\end{array}$ & 679 \\
\hline
\end{tabular}




\section{Appendix B: GIS Analysis of the Distribution and Estimated CO2 Storage Volume of the Devonian Shale in Kentucky}

Note: Grid data sets are indicated in matrix notation using the courier type face, i.e., [grid_data]

Geographic information system (GIS) software was used to perform an analysis of the thickness and distribution of the Devonian black shale in Kentucky. The initial goal is to calculate the number of tons of shale in place by county for those areas with drilling depths to the shale of at least 1,000 feet and a shale thickness of at least 50 feet. These cutoffs were selected to ensure reservoir integrity (deeper than the expected depth of surface fracturing) and gas reservoir potential. With the number of tons of shale being determined, a series of factors to calculate the sequestration potential in tons of $\mathrm{CO}_{2}$ are derived based on measured $\mathrm{CO}_{2}$ storage capacity and shale density. For GIS, ESRI's ArcView 3.2 and Spatial Analyst were used. The Kentucky Geological Survey uses a server running SQL-2000 for data storage. Data are accessed with tables linked to a graphic user interface implemented using Microsoft Access 97. Access queries were composed to compile point data sets consisting of the locations and values of Devonian shale stratigraphic tops and thickness. The formation tops data were maintained as drilling depth to the top of the formation rather than elevations with respect to sea level. Open database connectivity (ODBC) services are available from ArcView. The Access query results were added to the GIS as tables using the SQL Connect facility and then converted to shape files.

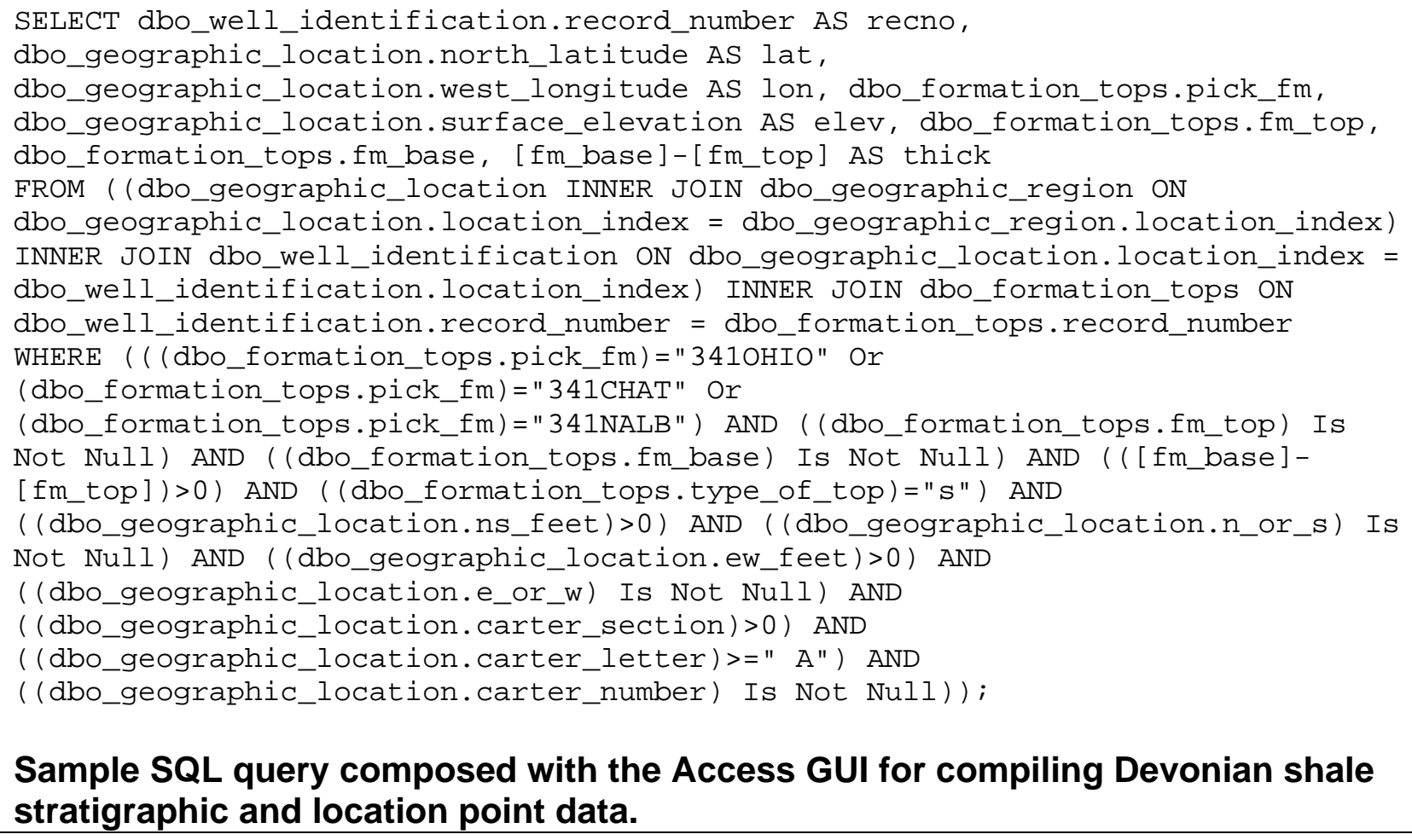

Sample SQL query composed with the Access GUI for compiling Devonian shale stratigraphic and location point data. 
Existing polygon shape files of the Kentucky counties, faults, and the subsurface distribution of the Devonian shale in Kentucky ( [Subsurf]) were employed in the analysis. The shape file of the subsurface distribution of the shale was converted to a grid for use in the spatial analysis. Each cell of this grid contained a value of 1 (true) if the shale existed in the subsurface over the area of the cell. All other cells were set to null, the no data value. All grids were computed with 1,000-meter (1 kilometer) cell dimensions. Analyses were performed using the North American Datum of 1927 (NAD27) with the projection set to UTM zone 16.

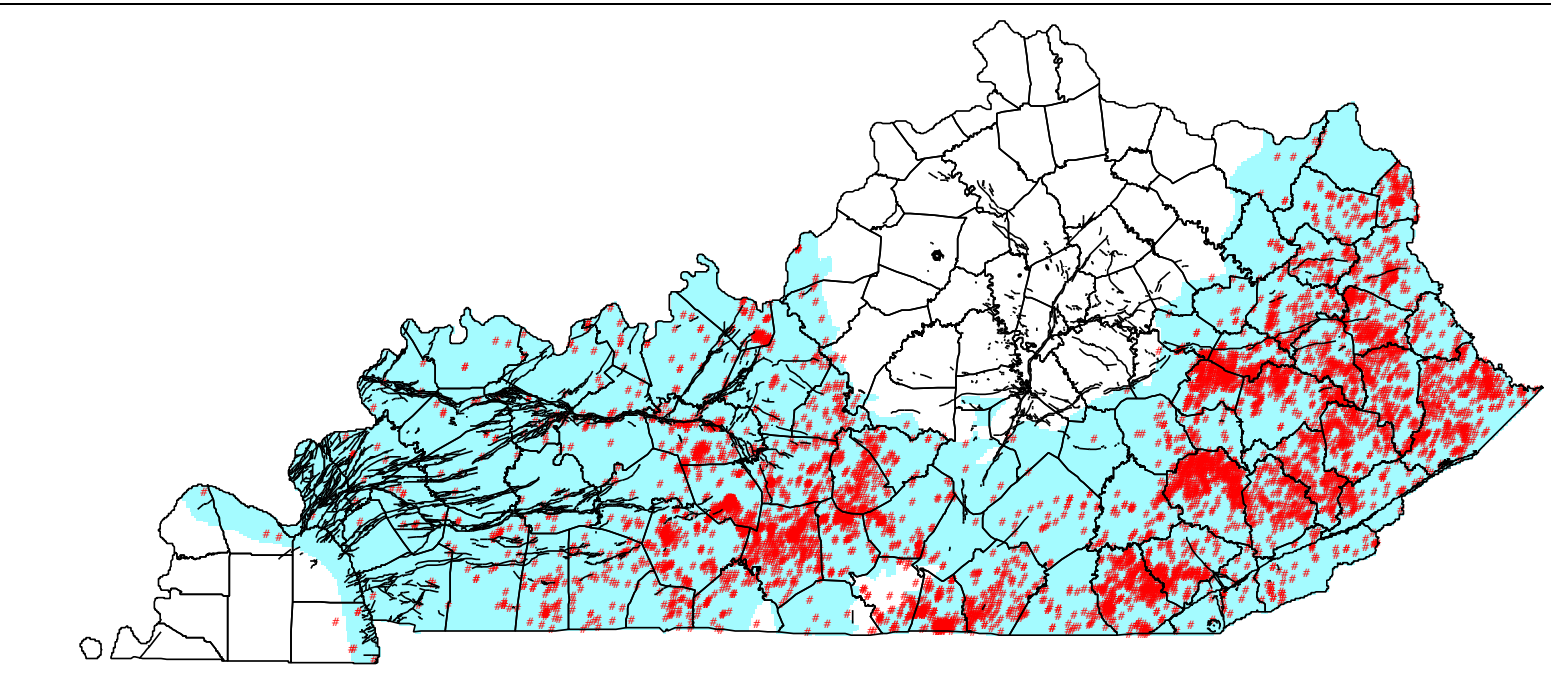

Subsurface distribution of the Devonian shale (blue, shaded) with stratigraphic data points.

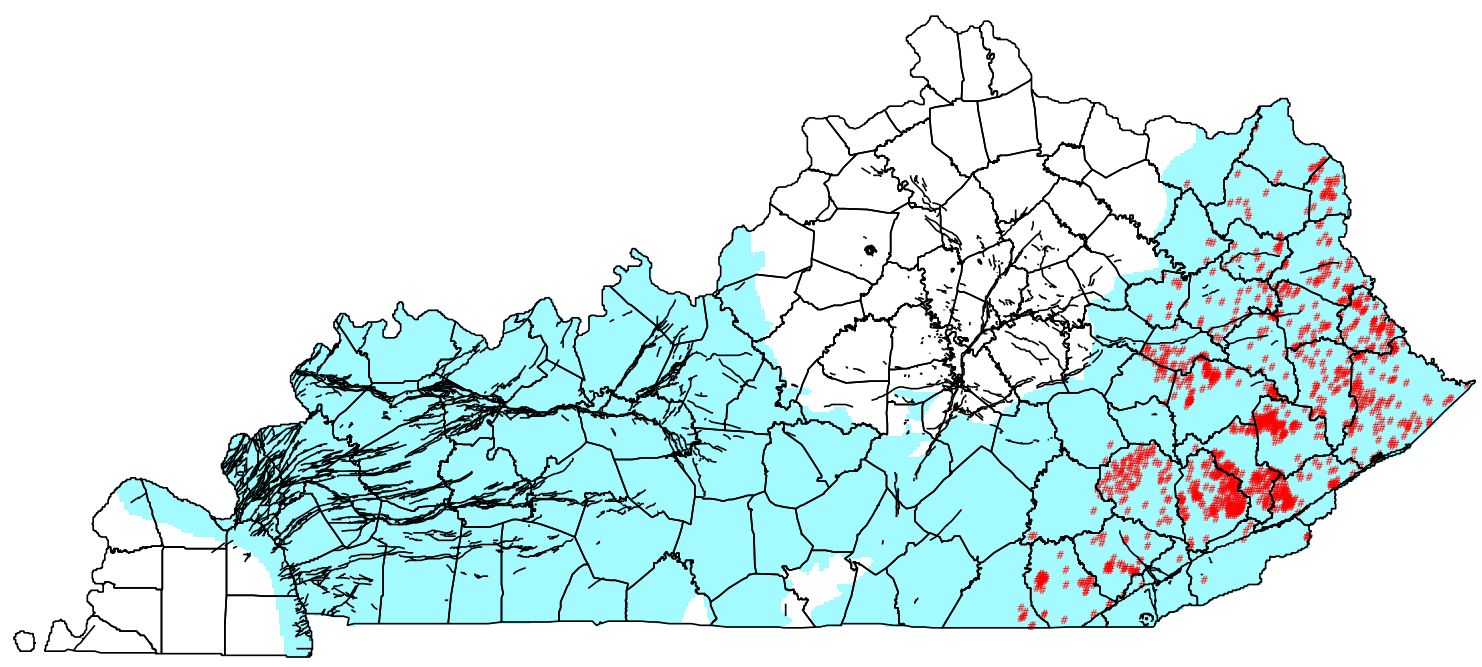

Subsurface distribution of the Devonian shale (blue, shaded) with stratigraphic data points for the Lower Huron Member of the shale.

For deriving drilling depth and thickness maps, grids were interpolated from point data using the inverse distance weighted (IDW) nearest neighbor method. The interpolated 
data were processed to establish which grid cells fit the selection criteria of 1,000 feet or deeper drilling depths and a shale thickness of at least 50 feet. 
Interpolate grid, [Depth], using drilling depth from point file Interpolate grid, [Iso], using thickness data from point file Map Query [Depth] $>=1000=[$ Deep]

Map Query [Iso] $>=50=[$ Thick $]$

Calculate [Deep]*[Thick] $=[$ Temp01]

Calculate [Temp01]*[Subsurf] $=[$ Temp02]

$([$ Temp02] $=0$. AsGrid).SetNull $([$ Temp02] $)=$ [DeepThick $]$

Method for deriving a grid dataset indicating the distribution of shale at least 50 feet thick and 1,000 feet deep.

To restrict the volume calculations to the limits of the distribution of thicker and deeper shale, the [Iso] and [DeepThick] grid data sets were multiplied together to produce a new grid, [ Target].

To limit the number of calculation steps required to derive volume and sequestration potential estimates, conversion factors were derived to convert the thickness (isopach in feet) data in [ Target] to million tons of shale and then directly to CO2 tons. Tons of shale in place is a function of shale volume and density, thus:

$$
\begin{gathered}
\text { Tons }_{\text {shale }}=\text { volume }^{*} \text { density } \\
\text { and } \\
\text { MMTons }_{\text {shale }}=\frac{\text { thickness }^{*} \text { area } * \text { density }}{1000000}
\end{gathered}
$$

Assuming thickness in feet, a1 kilometer cell size, a density in $\mathrm{g} / \mathrm{cc}$ million tons of shale in place can be calculated:

$$
\begin{array}{ll}
\text { MMTons }_{\text {shale }}=\frac{\text { thickness } * \frac{0.3048 m}{f t} *(1000 \mathrm{~m})^{2} * \text { density } * 1.102}{1000000} \\
\text { where: } \quad \begin{array}{ll}
\text { thickness } \\
1000
\end{array} \\
\begin{array}{ll}
\text { density } & \text { thickness of shale in feet } \\
1.102 & \text { cell size in meters } \\
& =\text { bulk density from compensated density log } \\
& \text { density conversion factor to convert from grams per } \\
& \text { cubic centimeter to tons per cubic meter }
\end{array}
\end{array}
$$


For a specified density, the constants in equation 1 can be combined to obtain a direct conversion factor that is a function only of shale thickness. Substituting different shale densities, a factor, CfMMTons, would be one of:

$2.5 \mathrm{~g} / \mathrm{cc}$ (log estimated density for Lower Huron)

$2.6 \mathrm{~g} / \mathrm{cc}$ (log estimated density for upper part of shale)

$2.65 \mathrm{~g} / \mathrm{cc}$ (log handbook typical shale density)

$$
\begin{aligned}
& =0.840 \\
& =0.873 \\
& =0.890
\end{aligned}
$$

To calculate million tons of shale per cell, the ArcView grid calculation would be:

$$
\text { [ Target }]{ }^{*} \text { CfMMTons.AsGrid }=[\text { MMTons }]
$$

Different conversion factors could be derived for standard reservoir analysis (as opposed to assuming adsorbed gas). Distributions of porosity, water or oil saturation data, and others could be gridded and used to derive oil or gas in place estimates.

Converting tons of shale in place to estimated tons of $\mathrm{CO}_{2}$ sequestered requires an additional factor based on the gas content per ton of shale from $\mathrm{CO}_{2}$ adsorption data. Using a gas content of 1 standard cubic foot of $\mathrm{CO}_{2}$ per ton and $17.25^{1}$ thousand cubic feet (Mcf) $\mathrm{CO}_{2}$ per ton of $\mathrm{CO}_{2}$, there will be 57.97 tons of $\mathrm{CO}_{2}$ per million tons of shale.

TonsCO $2=\frac{f t_{\mathrm{CO}_{2}}^{3}}{\text { ton }_{\text {shale }}} * 1000000 * \frac{M c f}{1000 f t_{\mathrm{CO}_{2}}^{3}} * \frac{\text { ton }_{\mathrm{CO}_{2}}}{17.25 M c f}=57.97 \quad$ Eq. 2

The sequestration volume in tons of $\mathrm{CO}_{2}$ can now be considered a function of thickness, shale density, and adsorbed gas content, or:

$$
\text { Tons } \mathrm{CO}_{2}=57.97 * \text { CfMMTons } * \text { thickness } * \text { gascontent }
$$

Multiplying the 57.97 and CfMMTons provides a single factor that varies only with density:

Factor $=48.69$ at density equals $2.5 \mathrm{~g} / \mathrm{cc}$

Factor $=50.61$ at density equals $2.6 \mathrm{~g} / \mathrm{cc}$

Factor $=51.59$ at density equals $2.65 \mathrm{~g} / \mathrm{cc}$

In lieu of gridding gas content data, multiplying a measured gas content by one of these factors yields a final selection of factors for use in converting shale thickness data directly to tons of $\mathrm{CO}_{2}$ sequestered. For example, using a gas content of $40 \mathrm{scf} / \mathrm{ton}$, a shale density of $2.6 \mathrm{~g} / \mathrm{cc}$, and a 1000 -meter cell size, the tons of $\mathrm{CO}_{2}$ per cell is 2024.3 per foot of shale thickness, thus:

$$
\text { [Target }] *(2024 \cdot 3) \cdot \text { AsGrid }=[\text { CO2Tons }]
$$

${ }^{1} 17.25 \mathrm{Mcf} \mathrm{CO}_{2}$ per ton $\mathrm{CO}_{2}$ is the conversion factor used by the U.S. EPA. Conversion is derived from gas laws and is valid for $60^{\circ} \mathrm{F}$ and 1 atmosphere pressure. 
As additional gas content data are acquired, examining the distribution and gridding the data as appropriate will be used to refine the sequestration volume calculations.

The values calculated for each cell require summation for specific regions to obtain totals. With the county polygon theme active, the ArcView Summarize Zones procedure (available from the Analysis menu command) was used to summarize the data by county. The field defining the zones was the county name and the [CO2Tons] grid theme was selected for summarizing. A table of summary statistics was computed that could be joined to the original county table for mapping and additional analysis.

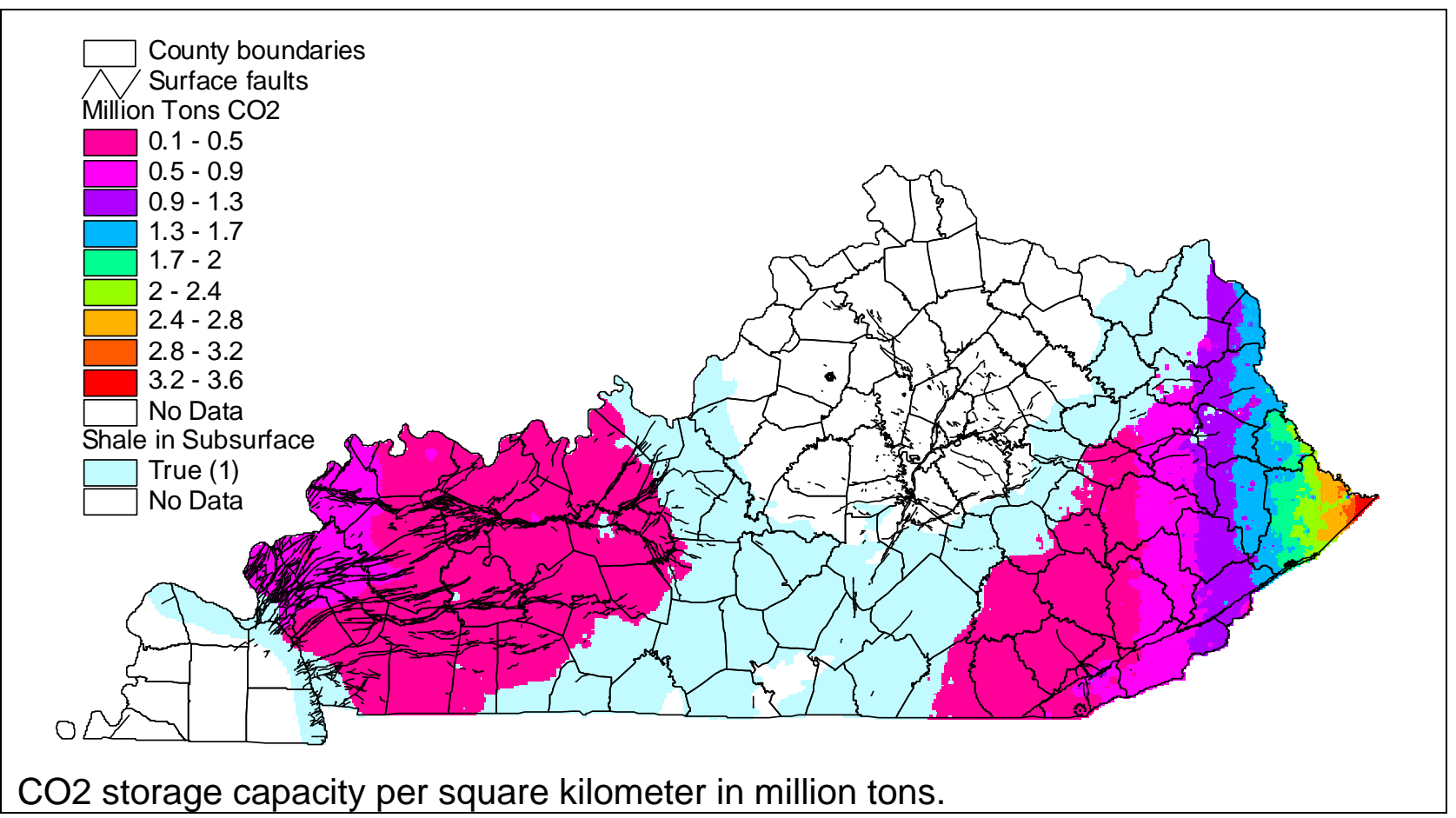

Summary by county of potential sequestration totals (gas content $40 \mathrm{scf} / \mathrm{ton}$, shale density $2.6 \mathrm{~g} / \mathrm{cc}$, cell size 1,000 meters):

\begin{tabular}{lrrrrrr}
\multicolumn{1}{c}{ Name } & Basin & Count & Min & Max & Mean & MMTonsCO2 \\
BELL & 160 & 949 & 0.24 & 1.52 & 0.51 & 486.8 \\
BOYD & 160 & 420 & 1.03 & 1.70 & 1.39 & 583.9 \\
BREATHITT & 160 & 1293 & 0.38 & 1.05 & 0.60 & 775.2 \\
CARTER & 160 & 329 & 0.34 & 1.26 & 1.05 & 346.6 \\
CLAY & 160 & 1236 & 0.24 & 0.48 & 0.35 & 433.2 \\
ELLIOTT & 160 & 292 & 0.29 & 1.14 & 0.92 & 267.2 \\
FLOYD & 160 & 1040 & 0.27 & 1.79 & 1.42 & $1,474.4$ \\
GREENUP & 160 & 339 & 0.99 & 1.38 & 1.24 & 421.7 \\
HARLAN & 160 & 1211 & 0.31 & 1.17 & 0.76 & 918.6 \\
JACKSON & 160 & 275 & 0.21 & 0.34 & 0.25 & 69.4 \\
JOHNSON & 160 & 657 & 0.86 & 1.67 & 1.28 & 839.8 \\
KNOTT & 160 & 918 & 0.78 & 1.42 & 1.06 & 969.9 \\
KNOX & 160 & 1017 & 0.20 & 0.47 & 0.31 & 318.5
\end{tabular}




\begin{tabular}{|c|c|c|c|c|c|c|}
\hline Name & Basin & Count & Min & Max & Mean & MMTonsCO2 \\
\hline LAUREL & 160 & 1146 & 0.16 & 0.38 & 0.22 & 255.7 \\
\hline LAWRENCE & 160 & 1089 & 0.20 & 1.85 & 1.37 & $1,490.6$ \\
\hline LEE & 160 & 232 & 0.22 & 0.50 & 0.35 & 81.6 \\
\hline LESLIE & 160 & 1066 & 0.38 & 0.79 & 0.55 & 590.8 \\
\hline LETCHER & 160 & 894 & 0.21 & 1.70 & 1.13 & $1,012.2$ \\
\hline MAGOFFIN & 160 & 793 & 0.63 & 1.20 & 0.92 & 730.8 \\
\hline MARTIN & 160 & 631 & 1.23 & 2.32 & 1.76 & $1,113.1$ \\
\hline MCCREARY & 160 & 703 & 0.10 & 0.24 & 0.15 & 107.8 \\
\hline MENIFEE & 160 & 16 & 0.37 & 0.42 & 0.39 & 6.2 \\
\hline MORGAN & 160 & 710 & 0.25 & 1.19 & 0.70 & 496.8 \\
\hline OWSLEY & 160 & 497 & 0.13 & 0.44 & 0.34 & 168.0 \\
\hline PERRY & 160 & 892 & 0.37 & 1.04 & 0.71 & 630.4 \\
\hline PIKE & 160 & 2056 & 0.82 & 3.60 & 2.17 & $4,467.3$ \\
\hline POWELL & 160 & 7 & 0.31 & 0.34 & 0.32 & 2.2 \\
\hline ROCKCASTLE & 160 & 4 & 0.19 & 0.21 & 0.20 & 0.8 \\
\hline ROWAN & 160 & 2 & 0.54 & 0.54 & 0.54 & 1.1 \\
\hline WHITLEY & 160 & 1161 & 0.16 & 0.70 & 0.22 & 261.1 \\
\hline WOLFE & 160 & 525 & 0.20 & 0.81 & 0.45 & 237.1 \\
\hline Appalachian & 160 Total & & & & & $19,558.9$ \\
\hline MARSHALL & 250 & 29 & 0.39 & 0.56 & 0.48 & 13.9 \\
\hline Jackson Purchase & 250 Total & & & & & 13.9 \\
\hline EDMONSON & 300 & 670 & 0.12 & 0.40 & 0.24 & 157.5 \\
\hline HARDIN & 300 & 220 & 0.13 & 0.18 & 0.16 & 35.3 \\
\hline HART & 300 & 178 & 0.11 & 0.20 & 0.15 & 26.4 \\
\hline MEADE & 300 & 106 & 0.18 & 0.22 & 0.20 & 21.6 \\
\hline PULASKI & 300 & 58 & 0.14 & 0.18 & 0.16 & 9.3 \\
\hline WARREN & 300 & 424 & 0.12 & 0.38 & 0.20 & 84.0 \\
\hline Cincinnati Arch & 300 Total & & & & & 334.2 \\
\hline BRECKINRIDGE & 315 & 1426 & 0.10 & 0.26 & 0.19 & 274.8 \\
\hline BUTLER & 315 & 1130 & 0.11 & 0.41 & 0.28 & 320.3 \\
\hline CALDWELL & 315 & 898 & 0.27 & 0.67 & 0.48 & 430.0 \\
\hline CHRISTIAN & 315 & 1870 & 0.11 & 0.58 & 0.25 & 470.0 \\
\hline CRITTENDEN & 315 & 968 & 0.31 & 0.90 & 0.66 & 634.1 \\
\hline DAVIESS & 315 & 1255 & 0.12 & 0.46 & 0.32 & 404.1 \\
\hline GRAYSON & 315 & 1277 & 0.12 & 0.49 & 0.27 & 343.6 \\
\hline HANCOCK & 315 & 516 & 0.15 & 0.54 & 0.29 & 150.5 \\
\hline HENDERSON & 315 & 1233 & 0.11 & 0.64 & 0.45 & 560.8 \\
\hline HOPKINS & 315 & 1464 & 0.14 & 0.64 & 0.41 & 595.7 \\
\hline LIVINGSTON & 315 & 696 & 0.42 & 0.67 & 0.60 & 415.6 \\
\hline LOGAN & 315 & 966 & 0.12 & 0.25 & 0.19 & 183.1 \\
\hline LYON & 315 & 620 & 0.28 & 0.59 & 0.46 & 284.8 \\
\hline MCLEAN & 315 & 671 & 0.14 & 0.56 & 0.39 & 259.9 \\
\hline MUHLENBERG & 315 & 1266 & 0.12 & 0.59 & 0.34 & 425.4 \\
\hline $\mathrm{OHIO}$ & 315 & 1549 & 0.16 & 1.09 & 0.37 & 573.4 \\
\hline TODD & 315 & 879 & 0.10 & 0.31 & 0.18 & 156.9 \\
\hline TRIGG & 315 & 848 & 0.16 & 0.34 & 0.24 & 200.6 \\
\hline UNION & 315 & 953 & 0.57 & 0.81 & 0.69 & 657.7 \\
\hline WEBSTER & 315 & 878 & 0.17 & 0.68 & 0.51 & 445.1 \\
\hline Illinois Basin & 315 Total & & & & & $7,786.5$ \\
\hline & \multicolumn{5}{|c|}{ Grand Total } & $27,693.5$ \\
\hline Year & \multicolumn{5}{|c|}{ vailable at $80,000,000$ tons $\mathrm{CO} 2$ per year } & 346.2 \\
\hline
\end{tabular}


The values shown in this table are provided to illustrate an application of the estimation method described in this appendix. The numbers are subject to revision and do not represent final conclusions of this project. Additional $\mathrm{CO}_{2}$ adsorption capacity data will be acquired to refine the estimates. Consideration will be given to other adjustments to the total that might include evaluating areas likely to have little or no sequestration potential even though they are mathematically included in the area of deep and thick shale. These areas will be excluded. For example, based on experience in oil and gas field exploration and development, Marshall, Pulaski, and Rockcastle counties are areas of marginal potential that have a relatively small likely-hood of being developed for carbon sequestration. 


\title{
Appendix C: CNR 24752 Elk Horn Coal
}

\author{
Recno: \\ 125651 \\ Permit: \\ Name: \\ 94539 \\ Loc: Knott County, KY, 1250 FSL 620 FWL 11-K-81 \\ Lat: \\ Lon: \\ $37.3701 \mathrm{~N}$ (NAD27) \\ $-82.764533 \mathrm{~W}$ \\ TD: \\ 3004 feet
}

Log measured from KB @ 1011'

\begin{tabular}{|c|c|c|c|c|c|c|c|}
\hline Era & Formation & Code & Top (feet) & Condition & Fluoresce & Comments & Shipped \\
\hline \multirow[t]{6}{*}{ Mssp } & Little Lime & 332LTLM & 1698 & & & & \\
\hline & Pencil Cave & 332PCCV & 1735 & & & & \\
\hline & Big Lime & 332BIGL & 1739 & & & & \\
\hline & Borden & 337BRDN & 1954 & & & & \\
\hline & Sunbury & 339SNBR & 2249 & & & & \\
\hline & Berea & 339BREA & 2283 & & & & \\
\hline \multirow[t]{17}{*}{ Devonian } & Ohio Shale & $341 \mathrm{OHIO}$ & 2346 & & & & \\
\hline & Cleveland Sh Mbr & 341CLVD & 2346 & & & & \\
\hline & Core 10 & 341CLVD & 2370 & Intact & No & dry, faint odor & Yes \\
\hline & Three Lick Bed & $341 T L B D$ & 2452 & & & & \\
\hline & Core 9 & $341 T L B D$ & 2455 & Intact & No & light gray & Yes \\
\hline & Core 8 & $341 T L B D$ & 2465 & Intact & No & $\begin{array}{l}\text { odor, dark oily black, } \\
\text { slick, sticky feel, but } \\
\text { not wet }\end{array}$ & Yes \\
\hline & Upper Huron Mbr & 341HURNU & 2488 & & & & \\
\hline & Core 7 & 341HURNU & 2530 & Intact & No & $\begin{array}{l}\text { slight odor, dark oily } \\
\text { black as in core } 8\end{array}$ & Yes \\
\hline & Middle Huron Mbr & 341HURNM & 2543 & & & & \\
\hline & Core 6 & 341HURNM & 2630 & Broken & No & $\begin{array}{l}\text { slight odor, waxy feel, } \\
\text { but not wet }\end{array}$ & No \\
\hline & Lower Huron Mbr & 341HURNL & 2726 & & & & \\
\hline & Core 5 & 341HURNL & 2730 & Intact & No & dry, somewhat mottled & Yes \\
\hline & Core 4 & 341HURNL & 2760 & Intact & No & dry, somewhat mottled & Yes \\
\hline & Core 3 & 341HURNL & 2780 & Intact & No & $\begin{array}{l}\text { dry, approx. } 0.5 \mathrm{~cm} \\
\text { pyrite clast, possible } \\
\text { faint odor }\end{array}$ & Yes \\
\hline & Core 2 & 341HURNL & 2835 & Broken & No & oily, strong odor & No \\
\hline & Olentangy & 341OLNG & 2838 & & & & \\
\hline & Core1 & 341 OLNG & 2900 & Broken & No & oily, strong odor & No \\
\hline
\end{tabular}

Core samples are identified by their respective measured depth from KB (i.e., Top value in bold) 


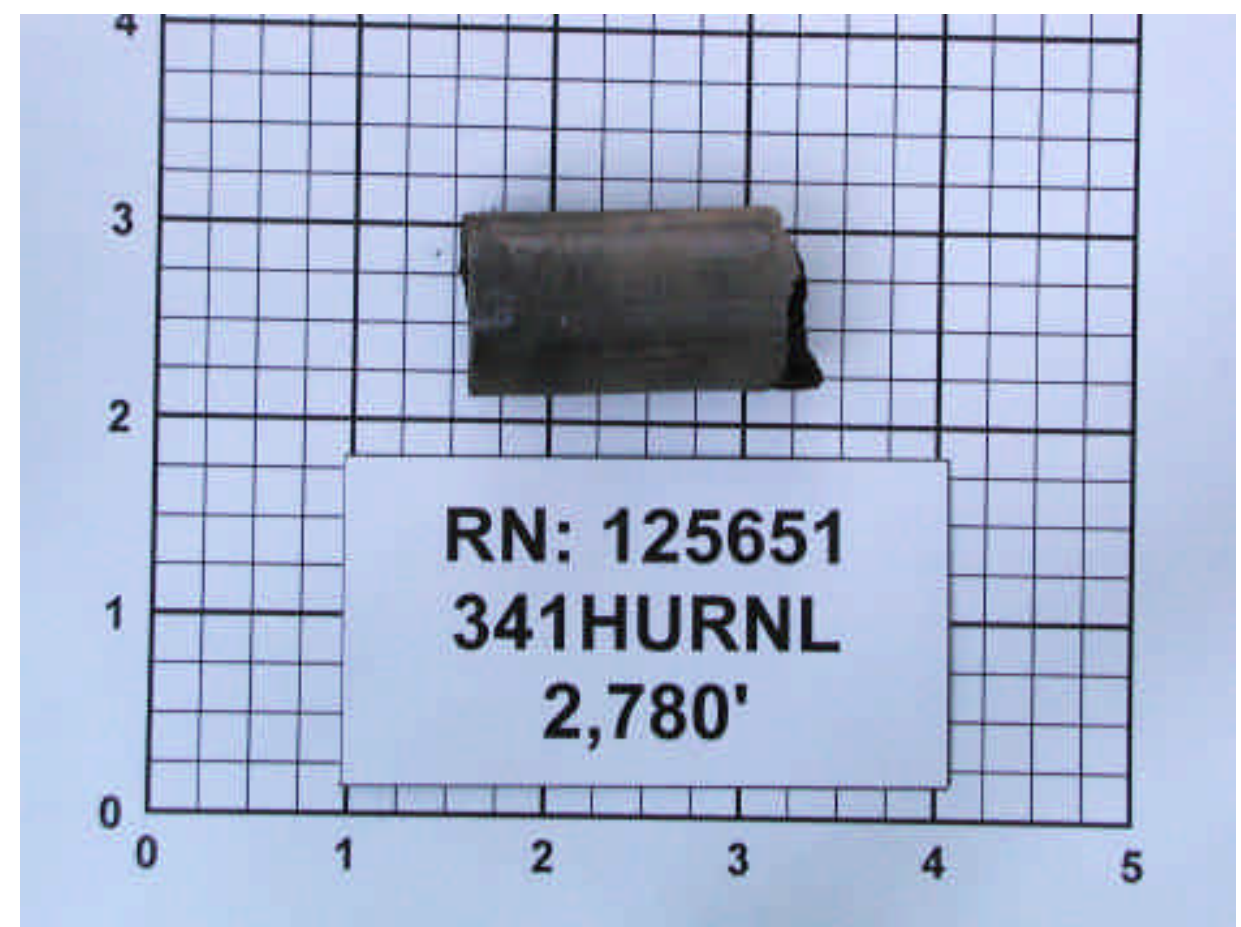

Sidewall core number $3(0.25$-inch grid).. This sample included a pyrite clast but is otherwise typical of the intact cores as submitted for analysis.

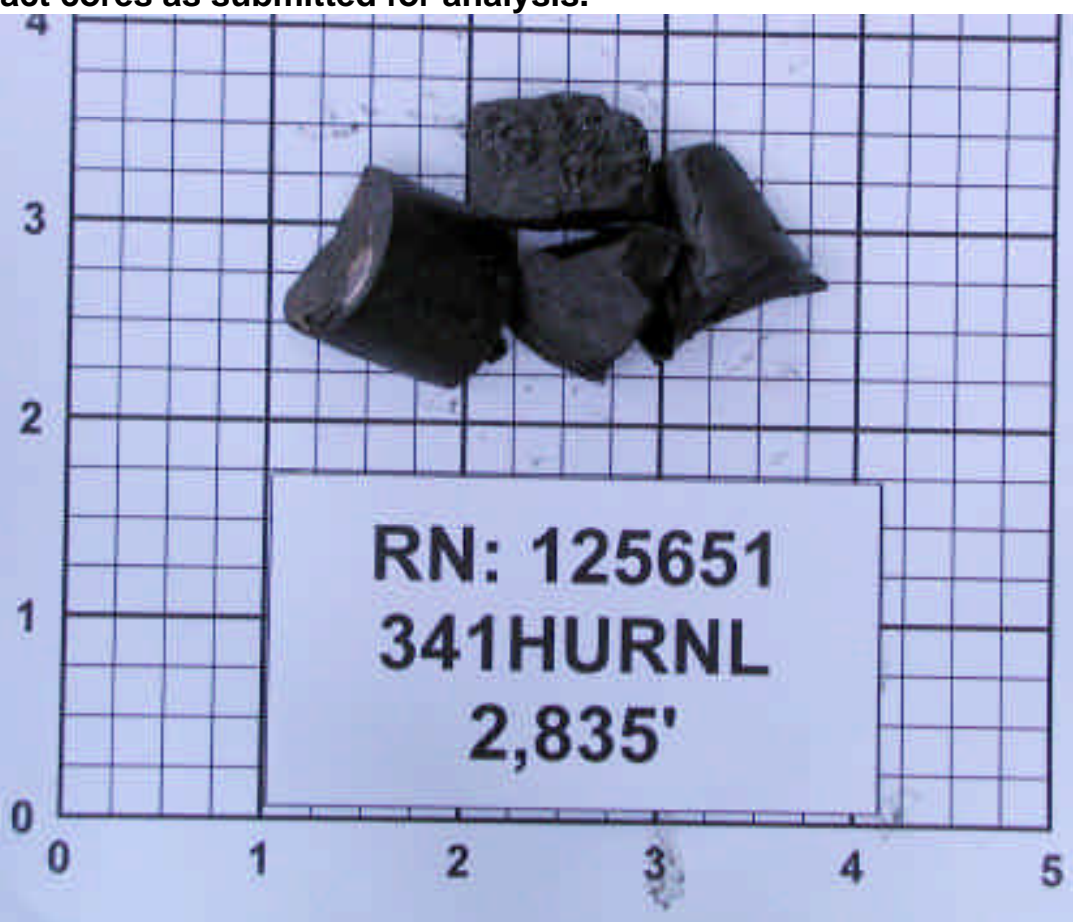

Sidewall core number 2 (0.25-inch grid). This sample exhibits an oily sheen characteristic of cores collected that were saturated with light hydrocarbons. This core is typical of the broken samples. 


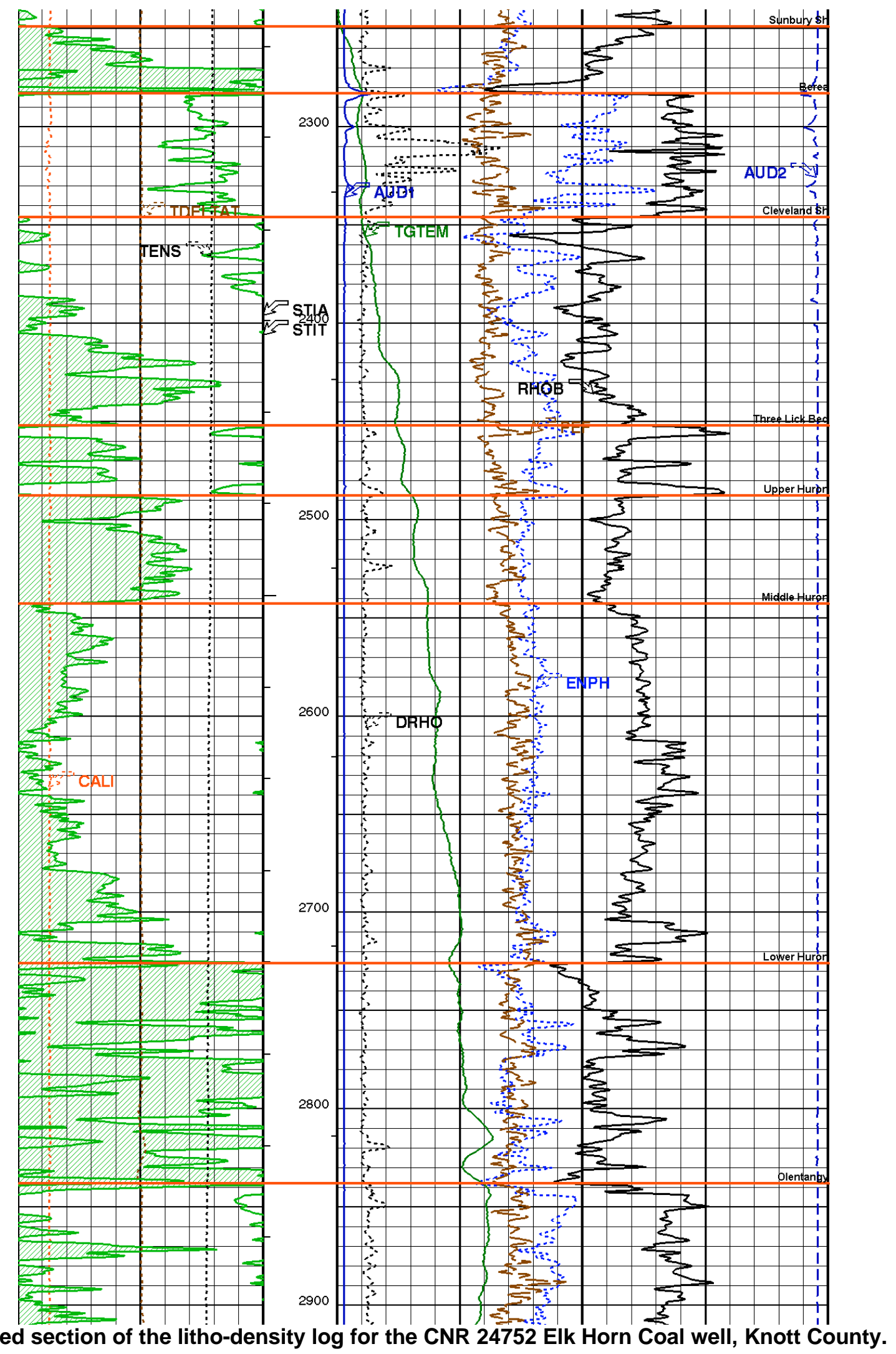




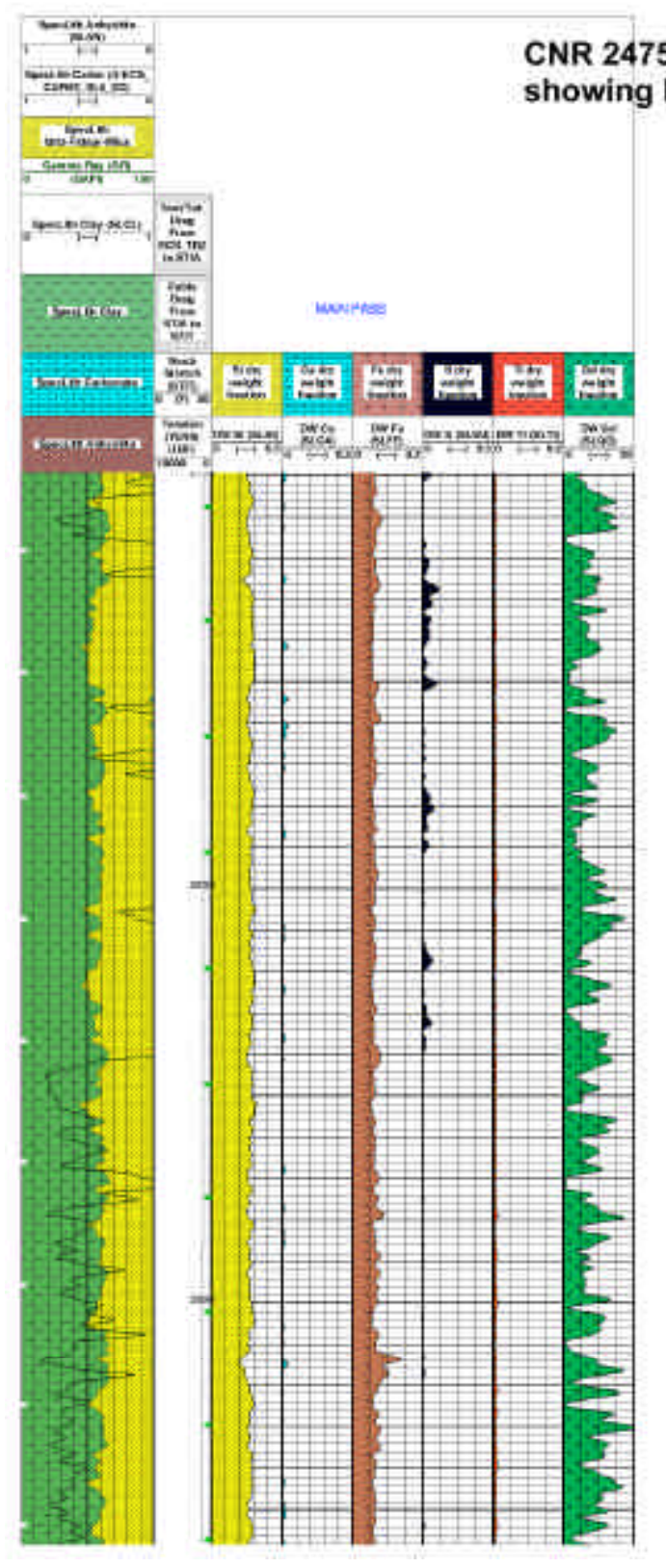

CNR 24752 Composite log suite through the (Devonian) Lower Huron

howing locations of recovered cores (red arrows, right track of Litho-Density log).

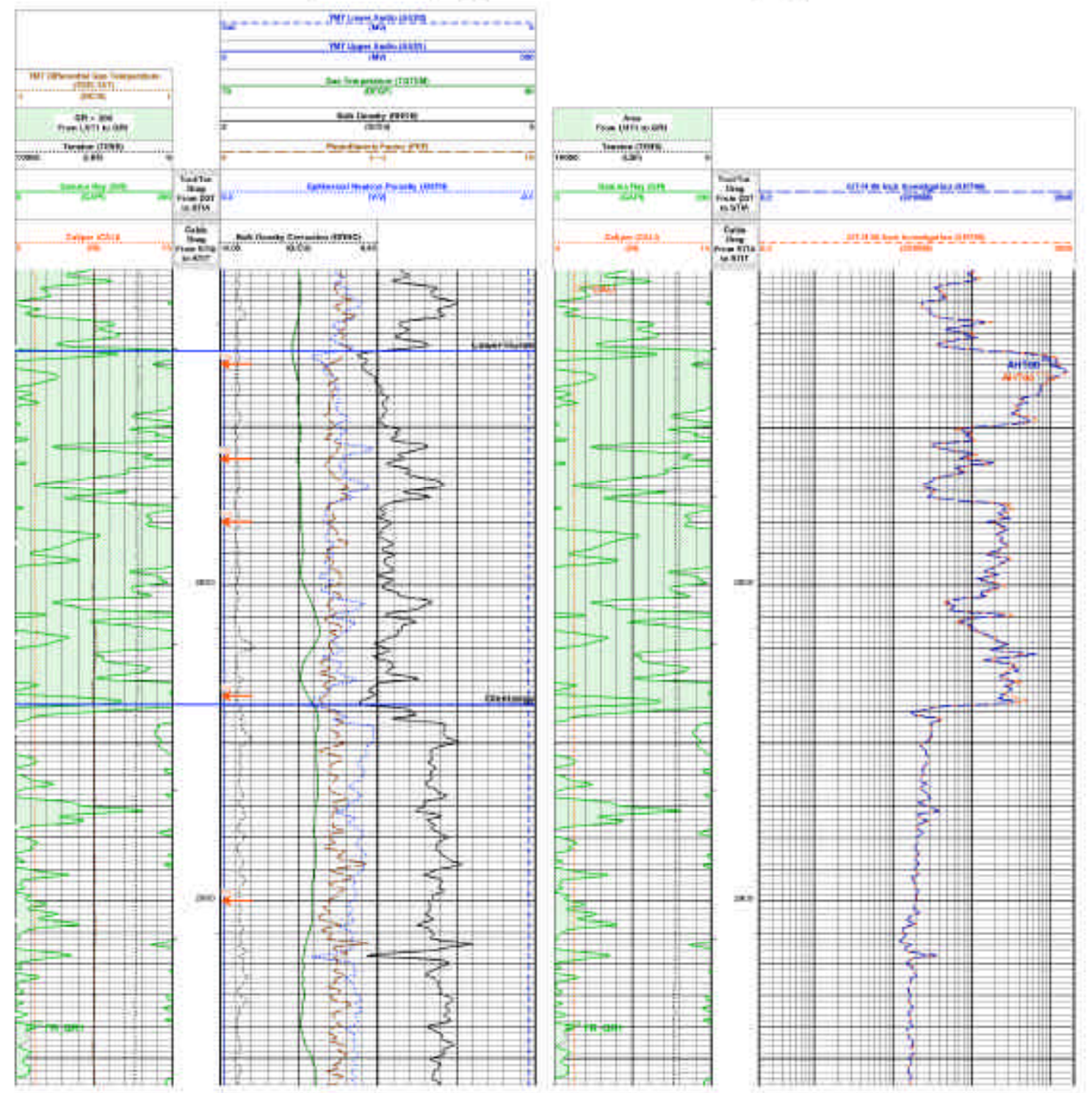


